\title{
Frontal prism Site U1412
}

R.N. Harris, A. Sakaguchi, K. Petronotis, A.T. Baxter, R. Berg, A. Burkett, D. Charpentier, J. Choi,

P. Diz Ferreiro, M. Hamahashi, Y. Hashimoto, K. Heydolph, L. Jovane, M. Kastner, W. Kurz, S.O. Kutterolf, Y. Li, A. Malinverno, K.M. Martin, C. Millan, D.B. Nascimento, S. Saito, M.I. Sandoval Gutierrez, E.J. Screaton, C.E. Smith-Duque, E.A. Solomon, S.M. Straub, W. Tanikawa, M.E. Torres, H. Uchimura, P. Vannucchi, Y. Yamamoto, Q. Yan, and X. Zhao ${ }^{2}$

\section{Chapter contents}

Background and objectives........... 1

Operations........................

Lithostratigraphy and petrology ........

Paleontology and biostratigraphy .......5

Structural geology. .............. 7

Geochemistry ................. 7

Physical properties ............. 10

Paleomagnetism ................ 11

References.................. 13

Figures.................. 14

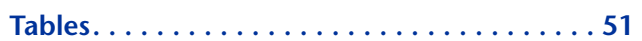

${ }^{1}$ Harris, R.N., Sakaguchi, A., Petronotis, K., Baxter, A.T., Berg, R., Burkett, A., Charpentier, D., Choi, J., Diz Ferreiro, P., Hamahashi, M., Hashimoto, $Y$., Heydolph, K., Jovane, L., Kastner, M., Kurz, W., Kutterolf, S.O., Li, Y., Malinverno, A., Martin, K.M. Millan, C., Nascimento, D.B., Saito, S., Sandoval Gutierrez, M.I., Screaton, E.J., Smith-Duque, C.E., Solomon, E.A., Straub, S.M., Tanikawa, W., Torres, M.E., Uchimura, H., Vannucchi, P., Yamamoto, Y., Yan, Q., and Zhao, X., 2013. Frontal prism Site U1412. In Harris, R.N., Sakaguchi, A., Petronotis, K., and the Expedition 344 Scientists, Proc IODP, 344: College Station, TX (Integrated Ocean Drilling Program).

doi:10.2204/iodp.proc.344.105.2013

'Expedition 344 Scientists' addresses.

\section{Background and objectives}

Integrated Ocean Drilling Program (IODP) Site U1412 (proposed Site CRIS-9A) targeted the frontal sedimentary prism, the main subduction thrust, the underthrust sedimentary section, and the upper oceanic crust. This site is along seismic Line BGR99-7 at common midpoint 4550 (Figs. F1, F2). The scientific objectives were to

1. Characterize the frontal sedimentary prism by documenting its lithology and age;

2. Sample the décollement at a shallow depth to define the deformation style, stress, fault friction, and behavior that influences coseismic displacement and plays an important in tsunami earthquakes;

3. Characterize any diagenetic processes, microstructures, and potential sealing/healing processes;

4. Characterize the physical properties of the subducting incoming and frontal prism sediments that are thought to mix with eroded upper plate material; and

5. Determine the chemistry of pore water within the wedge, décollement, and underthrust sections and characterize fluid pathways.

Wireline logging this site was a high priority to quantify the changes between underthrust material and input material.

This site was chosen because the frontal prism, subduction thrust, incoming sediment, and upper oceanic crust are well imaged with seismic reflection data (Fig. F1). The décollement is imaged as a high-amplitude negative-polarity reflection that indicates an inversion in seismic impedance. High heat flow measured in this area is interpreted as fluid flow in the upper oceanic crust, and estimating the style of flow is important.

Site U1412 consists of a $780 \mathrm{~m}$ thick section of upper plate sediments and $200 \mathrm{~m}$ of underthrust sediments (Fig. F1). The bottomsimulating reflector (BSR) is at 200 meters below seafloor (mbsf). Sediment above the BSR is relatively transparent with few coherent reflectors. Below the BSR, a series of landward-dipping reflectors are interpreted as faults. The décollement is at $780 \mathrm{mbsf}$ and is defined by a high-amplitude negative-polarity reflection. Near the toe of the margin, the décollement appears to cut sharply upward at $\sim 1 \mathrm{~km}$ landward of the deformation front. Below the décollement, the incoming sediment shows little internal coherence of reflectors. The top of the oceanic crust is well defined by a large-amplitude 
reflector. A series of steps in the basement reflector may represent blocks of oceanic crust offset by platebending normal faults.

\section{Operations}

\section{First transit to Site U1412}

After a $7.0 \mathrm{nmi}$ transit from Site U1380, the vessel stabilized over Site U1412 (proposed Site CRIS-9A) at $0200 \mathrm{~h}$ on 14 November 2012. The position reference used for dynamic positioning (DP) was a combination of GPS signals and an acoustic beacon, which was deployed at $0217 \mathrm{~h}$ on 14 November.

\section{Hole U1412A}

Upon arrival at Site U1412, an advanced piston corer (APC)/extended core barrel (XCB) bottom-hole assembly (BHA) was assembled and lowered to $1876 \mathrm{~m}$ water depth. After three unsuccessful attempts at recovering the mudline, Hole U1412A $\left(8^{\circ} 29.3294^{\prime} \mathrm{N}\right.$, $84^{\circ} 7.6686^{\prime} \mathrm{W}$ ) was spudded at $1520 \mathrm{~h}$ on 14 November 2012 at a water depth of $1921 \mathrm{~m}$. Nonmagnetic core barrels and the FlexIT orientation tool were used with Cores 344-U1412A-1H through 15H. Advanced piston corer temperature (APCT-3) tool formation temperature measurements were taken with Cores $3 \mathrm{H}$ and $5 \mathrm{H}-8 \mathrm{H}$. All cores after Core $3 \mathrm{H}$ were partial stroke cores, and APC refusal was reached at 108.2 mbsf with Core $15 \mathrm{H}$. After APC refusal was reached, the $\mathrm{XCB}$ coring system was deployed and coring continued through Core $25 \mathrm{X}$ to a final depth of $200.3 \mathrm{mbsf}$. At that time, the hole had become too unstable to continue coring. The hole was plugged with $49 \mathrm{bbl}$ of heavy mud and abandoned. The drill string was pulled from the hole, clearing the seafloor at $1410 \mathrm{~h}$ on 16 November and ending Hole U1412A.

Fifteen APC cores and ten XCB cores were recovered from Hole U1412A (Table T1). The APC cored interval was $108.2 \mathrm{~m}$ with $108.8 \mathrm{~m}$ recovered. The XCB cored interval was $92.1 \mathrm{~m}$ with $61.3 \mathrm{~m}$ recovered. Overall recovery for Hole U1412A was 85\%.

\section{Hole U1412B}

After clearing the seafloor, we attempted to recover the last XCB core barrel that had been deployed. The first attempt resulted in the aft coring line parting above the core barrel. Two wireline runs were made before eventually bringing the core barrel and sinker bars back to the surface. The vessel was offset $350 \mathrm{~m}$ south-southwest in the hope that the formation would be more suitable for a deeper hole. Hole U1412B $\left(8^{\circ} 29.1599^{\prime} \mathrm{N}, 84^{\circ} 7.7512^{\prime} \mathrm{W}\right)$ was spudded at $2350 \mathrm{~h}$ on 16 November 2012 at $1965 \mathrm{~m}$ water depth. Recovery of the mudline core was slightly problematic, as remnants of wireline from the previous wireline failure obstructed the overshot. After successfully clearing the debris, an XCB core barrel with a center bit was dropped and Hole U1412B was drilled from 6.7 to 155.8 mbsf. The center bit was replaced with an XCB core barrel, and coring began at $1700 \mathrm{~h}$ on 17 November. Cores 344-U1412B-3X through 20X were recovered to 304.3 mbsf. Coring over the last $75 \mathrm{~m}$ was punctuated by erratic and high torque. The drill string first became stuck at $233.4 \mathrm{mbsf}$. After working the pipe free with $14,000 \mathrm{lb}$ of overpull and $700 \mathrm{~A}$ of torque, the hole was cleaned and coring resumed. Coring continued until $2245 \mathrm{~h}$ on 19 November, when the drill string became firmly stuck for the second time. This time the string was freed from the formation with $90,000 \mathrm{lb}$ of overpull and $800 \mathrm{~A}$ of torque. When we were unable to wash back down to $304.3 \mathrm{mbsf}$, the decision was made to terminate coring and prepare the hole for logging operations.

With the bit at 289.4 mbsf, a $50 \mathrm{bbl}$ high-viscosity mud sweep was pumped to clean the hole. The drill string was then pulled to 231.3 mbsf. Four mud sweeps (total $=160 \mathrm{bbl}$ ) were pumped to try to keep the hole open. The wiper trip continued to $85.6 \mathrm{mbsf}$. Over the next $5.75 \mathrm{~h}$, we attempted to trip and wash back to bottom, eventually reaching a total depth of 289.4 mbsf. Another 50 bbl high-viscosity mud sweep was pumped, a go-devil was dropped to open the lockable float valve, and the hole was displaced with $130 \mathrm{bbl}$ of heavy logging mud. We then raised the drill pipe to $91.0 \mathrm{mbsf}$, and the logging tools were rigged up. The first logging run with the triple combination (triple combo) string started at $1040 \mathrm{~h}$ on 20 November. However, the tools were unable to exit the BHA and the drill string became stuck. The tools were pulled from the hole and were laid out at $1600 \mathrm{~h}$. The drill string was so firmly stuck that we were unable to lower the elevators the $1 \mathrm{~m}$ required to land them on the elevator stool, so the vessel had to be offset by $50 \mathrm{~m}$ to lower the elevators. Once the elevators had landed on the elevator stool, the top drive was picked up. With the top drive installed, the mud pumps were turned on and circulation was reestablished. The drill pipe was slowly pulled from the hole, and the vessel moved back over the hole. The remainder of the drill string was pulled to the surface, and the bit cleared the rotary table at $2245 \mathrm{~h}$ on 20 November, ending Hole U1412B.

One APC core was taken over a $6.7 \mathrm{~m}$ interval with $6.74 \mathrm{~m}$ recovered (101\%) (Table T1). Eighteen XCB cores were taken over a $148.5 \mathrm{~m}$ interval with $21.52 \mathrm{~m}$ recovered $(15 \%)$. Total recovery in Hole U1412B was $28.26 \mathrm{~m}$ (18\%). Total time spent on Hole U1412B was $104.5 \mathrm{~h}$. 


\section{Hole U1412C}

After the drill string cleared the rig floor, the vessel was offset $20 \mathrm{~m}$ north-northeast. The rotary core barrel (RCB) coring BHA was picked up and run to just above the seafloor. Seafloor depth for Hole U1412C was set at $1965.0 \mathrm{~m}$ from the offset depth at the previous hole. Hole U1412C $\left(8^{\circ} 29.1700^{\prime} \mathrm{N}, 84^{\circ} 7.7467^{\prime} \mathrm{W}\right)$ was spudded at $0730 \mathrm{~h}$ on 22 November 2012 and was drilled with a center bit to $300 \mathrm{mbsf}$ in $20 \mathrm{~h}$. The hole was then cleaned with a 40 bbl high-viscosity mud sweep. Coring continued with Cores 344U1412C-2R through $10 \mathrm{R}$ to a final depth of 387.0 mbsf. Excessive torque (>800 A) was present while cutting the final core, and in order to pull the final core, the bit had to be pulled back to $326 \mathrm{mbsf}$. However, high torque was still present at $326 \mathrm{mbsf}$, and the drill string had to be pulled back all the way to 239 mbsf. We then attempted to wash back to bottom to resume coring. After several hours of working to clean the hole, we reached 307 mbsf. High and erratic torque was still present. Because of the lack of progress and difficult drilling conditions, the decision was made to abandon Hole U1412C. The drill string was tripped to the surface, and the bit cleared the rotary table at $2115 \mathrm{~h}$. The acoustic beacon was recovered at $1815 \mathrm{~h}$, and the rig floor was secured for transit at $2200 \mathrm{~h}$ on 23 November, ending Hole U1412C.

Nine RCB cores were taken over an $87.0 \mathrm{~m}$ interval with $36.6 \mathrm{~m}$ recovered (42\%) (Table T1). Total time spent on Hole U1412C was $71.25 \mathrm{~h}$. The vessel proceeded to Site U1413 before returning.

\section{Second transit to Site U1412}

After a $15.0 \mathrm{nmi}$ transit from Site U1413, the vessel stabilized over Site U1412 at $0330 \mathrm{~h}$ on 1 December 2012. The initial position was the official location of Hole U1412B, and the vessel was then offset $50 \mathrm{~m}$ south-southwest in the hope that the décollement could be reached at a shallower depth. The position reference used for DP was a combination of GPS signals and an acoustic beacon, which was deployed at $0418 \mathrm{~h}$ on 1 December.

\section{Hole U1412D}

An RCB BHA with a used 97/8 inch bit was made up and lowered to just above the seafloor. Hole U1412D $\left(8^{\circ} 29.1402^{\prime} \mathrm{N}, 84^{\circ} 7.7793^{\prime} \mathrm{W}\right)$ was spudded at $0850 \mathrm{~h}$ on 1 December 2012 at $1973 \mathrm{~m}$ water depth. Drilling without recovery continued with a center bit for $19.75 \mathrm{~h}$ to $350.4 \mathrm{mbsf}$. The hole was cleaned with a $40 \mathrm{bbl}$ high-viscosity mud sweep, and the center bit was recovered with the wireline. Coring continued with nonmagnetic RCB core barrels for Cores 344U1412D-2R and 3R to a final depth of 369.2 mbsf.
Excessive torque ( $>500 \mathrm{~A}$ ) was present while cutting the final core. After adding another single joint of drill pipe and dropping the next core barrel, we were unable to advance the hole. Constant high torque (1000 A) kept stalling the top drive, and we had to offset the vessel $60 \mathrm{~m}$ from the hole location in order to free the stuck drill string. All efforts to condition the hole and continue coring failed, and the decision was made to abandon the hole. The seafloor was cleared at $1630 \mathrm{~h}$, and the beacon was recovered at $1735 \mathrm{~h}$ on 2 December. After recovering the beacon, the vessel began a slow move using the DP system to Site U1414. During the transit to the next site, the remainder of the drill string was recovered. The bit cleared the rotary table at $2105 \mathrm{~h}$ on 2 December, ending Hole U1412D and Site U1412.

Two RCB cores were taken over an $18.8 \mathrm{~m}$ interval with $12.3 \mathrm{~m}$ recovered (65\%) (Table T1). Total time spent on Hole U1412D was $41.5 \mathrm{~h}$. Total time spent on Site U1412 was 277.5 h, or 11.56 days.

\section{Lithostratigraphy and petrology}

Site U1412 was drilled to investigate the lithostratigraphy and structural geology of the slope-toe sequence and the uppermost portions of the basement, as interpreted in multichannel seismic reflection data. The primary goal of this site was to penetrate the décollement and investigate the fluid flow regime within the sediment and the oceanic crust. Four holes were cored at Site U1412, from 0 to 108.20 mbsf with the APC (Cores 344-U1412A-1H through $15 \mathrm{H}$ ), from 108.20 to 304.34 mbsf with the XCB (Cores 344-U1412A16X through 25X and 344-U1412B-3X through 20X), from 300.00 to 387.00 mbsf with the RCB (Cores 344-U1412C-1R through 10R), and finally, further downslope, from 350.40 to $363.98 \mathrm{mbsf}$ with the RCB (Cores 344-U1412D-2R and 3R). Overall core recovery at this site was moderate (average $=59 \%$ ) but became poor $(<20 \%)$ toward the bottom of Holes U1412B-U1412D. Three units were distinguished in the sedimentary rocks (Fig. F3; Table T2). Unit I is predominantly dark greenish to greenish gray clay $(50 \%)$ with small variations in grain size to silt (24\%) and silty clay (26\%) and contains eight tephra layers. This unit is terrigenous-influenced sediment. Unit I shows strong indications for gas expansion and gas hydrate disassociation. Unit II is a light to dark grayish brown calcareous nannofossil ooze with varying amounts of diatoms and sponge spicules. Primary sedimentary structures were not observed because of very strong drilling disturbances. Unit III is a sequence of grayish green clayey siltstone with minor interlayered sandstone and contains five dark grayish tephra layers. Its dominant matrix composition is terrigenous (clay) and contains nannofossils and 
radiolarian and diatom fragments. The sediment in Hole U1412D is slightly more clayey, is highly bioturbated, and shows a decrease in biogenic components.

\section{Description of units}

The $387 \mathrm{~m}$ long combined sedimentary sequence of Hole U1412A (Cores 344-U1412A-1H through 25X), Hole U1412B (Cores 344-U1412B-1H through 20X), Hole U1412C (Cores 344-U1412C-1R through 10R), and Hole U1412D (Cores 344-U1412D-2R through $3 \mathrm{R}$ ) is assigned to three lithostratigraphic units (Fig. F3; Table T2).

\section{Unit I (Holes U1412A and U1412B)}

Intervals: Sections 344-U1412A-1H-1, $0 \mathrm{~cm}$, to $25 \mathrm{X}-\mathrm{CC}, 53 \mathrm{~cm}$, and $344-\mathrm{U} 1412 \mathrm{~B}-1 \mathrm{H}-1,0 \mathrm{~cm}$, to $8 \mathrm{X}-1,44 \mathrm{~cm}$

Thickness: $204.74 \mathrm{~m}$

Depth: 0.00-204.74 mbsf

Age: Holocene to early Pleistocene

Lithology: calcareous clay with minor silt and silty clay

Unit I is massive dark greenish gray clay intercalated with silty clay horizons that become more calcareous rich toward the bottom of Hole U1412A (Fig. F4). Unit I contains eight tephra layers and a glauconiterich layer.

The clay sediment is slightly bioturbated and moderately well cemented by calcite. Silty clay horizons are dispersed throughout the length of the unit, with only a few silty-sandy horizons confined to two sections in the middle of Hole U1412A (Cores 344-U1412A$13 \mathrm{H}$ and $14 \mathrm{H}$ ). Abundant sponge spicule-filled pods ranging in size from a few millimeters to $\sim 1 \mathrm{~cm}$ are disseminated throughout the sediment, but their occurrence decreases toward the bottom of Hole U1412A, becoming rare in Hole U1412B.

The tephra layers in Unit I range in thickness from 2 to $7 \mathrm{~cm}$ and are characterized by a dark or light greenish gray color, normal grading, sharp to gradational upper contacts, and sharp lower contacts (Fig. F5). Ash pods, a few millimeters thick, are disseminated throughout both holes. The glauconite-rich layer is $\sim 10 \mathrm{~cm}$ thick and has contacts that are sharp to gradational (Fig. F6). Common centimeter-sized pods of glauconite also occur in the uppermost $10 \mathrm{~m}$ of both holes.

The main matrix components of Unit I are terrigenous and dominated by clay. Smear slides indicate that the most common accessory grains in the silty clay include feldspar and lithic (sedimentary and magmatic) fragments. Trace components include amphibole, calcite, biotite, quartz, chlorite, glass shards, pyroxene, and opaque minerals. Biogenic components include nannofossils, diatoms, and radiolarian and foraminifer fragments. The nannofossil component becomes dominant with depth.

Unit I is moderately to highly disturbed by gas hydrate in Hole U1412A and fractured by drilling in Hole U1412B.

\section{Unit II (Holes U1412B and U1412C)}

Intervals: Sections 344-U1412B-8X-1, $44 \mathrm{~cm}$, to 20X-CC, $4 \mathrm{~cm}$, and 344-U1412C-1R-1, $0 \mathrm{~cm}$, to 5R-CC, $10 \mathrm{~cm}$

Thickness: $126.27 \mathrm{~m}$

Depth: 204.74-331.01 mbsf

Age: early to middle Miocene

Lithology: Calcareous ooze with nannofossils and biogenic silica

Unit II is light to dark grayish brown silt-sized calcareous ooze with abundant biogenic silica (i.e., diatoms and sponge spicules) (Fig. F7). The massive upper part of the calcareous ooze becomes more lithified downhole and grades from very conspicuous white and laminated, $50 \mathrm{~cm}$ thick diatomaceous ooze into grayish brown nannofossil ooze (Fig. F8). Because of the high degree of drilling disturbance, no observations could be made regarding bioturbation. Good recovery and less disturbance in the lowermost portion of the unit allow for the identification of lamination and bedding structures, as well as reworked material.

The main matrix components of Unit II are calcareous (nannofossils and foraminifers) and silicic (sponge spicules, diatoms, and radiolarians) biogenic components. Additionally, microscopic observations of smear slides indicate that the most common accessory grains in the ooze include feldspar, glass, and lithic (sedimentary and magmatic) fragments. Trace components include amphibole, calcite, chlorite, and opaque minerals.

The uppermost $30 \mathrm{~m}$ of recovered sediment has a chaotic mousse-like structure due to the extensive drilling disturbance. Downhole, progressively coarse sand and pebble- to cobble-sized drill cuttings appear, often intermixed with fall-in material from the upper part of the hole.

\section{Unit III (Holes U1412C and U1412D)}

Interval: Sections 344-U1412C-5R-CC, $10 \mathrm{~cm}$, to 10R-CC, $19 \mathrm{~cm}$, and 344-U1412D-2R-1, $0 \mathrm{~cm}$, to 3R-CC, $15 \mathrm{~cm}$.

Thickness: Hole U1412C $=55.99$ m; Hole U1412D $=13.58 \mathrm{~m}$

Depths: Hole U1412C = 331.01-387.00 mbsf; Hole $\mathrm{U} 1412 \mathrm{D}=350.40-363.98 \mathrm{mbsf}$

Age: late Pliocene to early Pleistocene

Lithology: clayey siltstone with sandstone 
Unit III is clayey siltstone with minor interlayered sandstone (Fig. F9) and contains five dark grayish tephra layers (two in Hole U1412C and three in Hole U1412D) that are as thick as $10 \mathrm{~cm}$ (Fig. F10). Sediment is dark grayish green clay with silt in Hole U1412D.

Within core sections that experienced the least drilling disturbance, bioturbation appears to be quite abundant, with common burrows.

The slightly calcareous clayey siltstone layers are well sorted and mostly massive. Rare laminations appear in both the siltstone and sandstone, with the latter occasionally showing reworked sedimentary lithic lenses (Fig. F9). The abundance of sand horizons increases gradually toward the base of the hole and becomes most abundant in Core 344-U1412C-8R. The sandstone beds do not show clear contacts with the underlying siltstones. Organic material (e.g., sapropel) in the sediment is generally sporadic but appears to increase in abundance toward the bottom of the hole.

Siltstone and sandstone smear slides indicate that the dominant matrix composition is clay with abundant feldspar and sedimentary rock fragments, rare to common opaque minerals, calcite, quartz, hornblende, and glauconite, along with rare biotite, pyroxene, and volcanic glass. Biogenic components identified in smear slides include common nannofossils and fragments of foraminifers, radiolarians, and diatoms. Biogenic components are much diminished in Hole U1412D.

\section{X-ray diffraction analyses}

Preliminary X-ray diffraction (XRD) analyses of sediment from Holes U1214A-U1214C suggest that there is little variation in composition within the site (Fig. F11).

\section{Unit I}

The major mineral components of Unit I are phyllosilicates, including chlorite and smectite, quartz, plagioclase, and calcite. Zeolites (laumontite and heulandite), analcime, hornblende, and pyrite are also present in all samples. Small variations in the proportion of calcite and hornblende are observed. Biotite was only observed in three samples.

\section{Unit II}

The major mineral component of Unit II is calcite. Other identified minerals include pyrite and dolomite (Fig. F11). Dolomite is present in various proportions until it becomes nearly absent from Section 344U1412B-8X-CC to the bottom of Unit II.
Based on the background XRD patterns, we can conclude that Unit II samples contain a large amount of amorphous material.

\section{Unit III}

Two Unit III samples show that the major mineral components are phyllosilicates, including chlorite and smectite, quartz, calcite, and plagioclase (Fig. F11). Zeolites and hornblende are present in small amounts. The presence of amorphous material in Unit III could not be established.

\section{Depositional environment}

The lithology of Site U1412 represents typical lower slope sediments that are dominated by terrigenous sediment. In the lower part of the hole (204 mbsf) the lithology (Unit II) changes abruptly to Miocene calcareous ooze similar to that found at Sites U1381 and U1414, before changing to Pleistocene hemipelagic sediment again. This alternating sequence probably reflects accretion of large slivers from the incoming frontal prism.

\section{Paleontology and biostratigraphy}

We examined the microfossil content of core catcher samples from Holes U1412A-U1412C. Calcareous nannofossils and radiolarians provided biostratigraphic age estimates, and benthic foraminifers were used to characterize paleoenvironmental changes at Site U1412.

\section{Calcareous nannofossils}

Calcareous nannofossil abundance and preservation varied considerably at Site U1412 (Table T3). In Hole U1412A, nannofossils ranged from abundant to rare, with preservation from good to poor. Samples 344U1412A-1H-CC and 2H-CC are assigned to Zone NN21, based on the presence of Emiliania huxleyi. For Samples 344-U1412A-3H-CC through 19X-CC, the age is less well constrained and is assigned to Zones NN19-NN21 (1.89 Ma to present). The first appearance of Pseudoemiliania lacunosa, which defines the top of Zone NN19, occurs in Sample 344U1412A-20X-CC. Sample 344-U1412A-25X-CC contains the first appearance of the genus Discoaster spp., which constrains the base of Hole U1412A to Zones NN19-NN18 (1.89-2.39 Ma).

Nannofossil assemblages from the top of Hole U1412B overlap with those from the base of Hole U1412A. Samples 344-U1412B-3X-CC and 4X-CC are indicative of Zones NN19-NN21. Sample 344-U1412B5X-CC, containing P. lacunosa, places Samples 5X-CC through $7 \mathrm{X}-\mathrm{CC}$ in Zone NN19. The presence of $E$. 
huxleyi in Samples 344-U1412B-6X-CC and 7X-CC might suggest contamination, potentially due to the difficult drilling conditions. A major change in assemblage occurs between Samples 344-U1412B-7X-CC and $8 \mathrm{X}-\mathrm{CC}$, coinciding with a change in lithology from green claystone to nannofossil ooze (see "Lithostratigraphy and petrology"). Samples 344-U1412B$8 X-C C$ through 19X-CC contain a middle Miocene (Zone NN5) assemblage, including Sphenolithus moriformis, Sphenolithus heteromorphus, Coccolithus pelagicus, Discoaster spp., Cyclicargolithus floridanus, and Reticulofenestra pseudoumbilicus. This middle Miocene assemblage is also found in Samples 344-U1412C2R-CC through 5R-CC. A change from Miocene to Pleistocene assemblages occurs at the top of Core 344-U1412C-6R and is coincident with a change in lithology from nannofossil ooze to green claystone.

\section{Radiolarians}

The siliceous fraction is dominated by radiolarians and diatoms, with a minor proportion of sponge spicules. Radiolarians at this site are generally common and well preserved, with the exception of Samples 344-U1412C-5R-CC through 7R-CC.

Radiolarian assemblages from Sample 344-U1412A1H-CC through 344-U1412B-8X-CC (Unit I) are representative of the Pleistocene-Holocene. However, detailed biostratigraphic zonations could not be assigned to this interval because of the lack of diagnostically important species. The presence of Pterocorys minythorax and Amphirhopalum ypsilon suggests a depositional sequence $<1.8 \mathrm{Ma}$ (above Zone RN14; Sanfilippo and Nigrini, 1998). Species such as Acrosphaera trepanata, Sphaeropyle langii, Dictyophimus crisiae, Botryostrobus auritus, and Didymocyrtis tetrathalamus are characteristic of this assemblage.

Assemblages in Samples 344-U1412B-8X-CC through 344-U1412C-4R-CC (Unit II) are indicative of the early middle Miocene (Zones RN5-RN4). Cores 344U1412B-8X through 18X are assigned to Zone RN5 (14.98-12.02 Ma; Kamikuri et al., 2009). Samples 344-U1412B-19X-CC through 344-U1412C-4R-CC are constrained to Zone RN4 (14.98-17.03 Ma; Kamikuri et al., 2009). Marker species for Zones RN4-RN5 include Didymocyrtis mammifera, Didymocyrtis laticonus, Cyrtocapsella cornuta, Cyrtocapsella tetrapera, Liriospyris parkerae, Tholospyris kantiana, Periphaena decora, Centrobotrys thermophila, and Giraffospyris sp. (Table T4). Because of poor preservation and low abundances, Samples 344-U1412C-5R-CC through 10R-CC (Unit III) were not assigned to a biostratigraphic zone.

\section{Benthic foraminifers}

Benthic foraminifers were studied in 41 core catcher samples: 21 from Hole U1412A, 15 from Hole
U1412B, and 5 from Hole U1412C (Table T5). Three additional samples from working-half sections were taken at intervals 344-U1412A-19X-6W, 21-24 cm, and $344-\mathrm{U} 1412 \mathrm{~B}-1 \mathrm{H}-1 \mathrm{~W}, 0-2 \mathrm{~cm}$, and $8 \mathrm{X}-1 \mathrm{~W}, 54-$ $56 \mathrm{~cm}$. Benthic foraminifer abundances range from common to present and preservation from good to moderate in the upper and middle sections of Unit I (Samples 344-U1412A-1H-CC through 18X-CC). Abundance decreases significantly in the middle and lower sections of Unit I (Samples 344-U1412A-19XCC through 344-U1412B-7X-CC). Foraminifers are abundant to common at the top of Unit II (Samples 344-U1412B-8X-1W, 54-56 cm, and 9X-CC). Preservation and abundance decrease downhole within Unit II, with foraminifers becoming rare and strongly recrystallized, especially in the uppermost section of Hole U1412C (Samples 344-U1412C-2RCC through 6R-CC). Samples contained within Unit III (Samples 344-U1412C-7R-CC and 9R-CC), contain similar species to the ones in Unit I. Throughout Unit III, benthic foraminifers are rare or present.

Benthic foraminifer assemblages indicate two distinct paleoenvironments at Site U1412 that correspond closely with the lithostratigraphic units and biostratigraphic zones. The upper interval (Samples 344-U1412A-1H-CC through 344-U1412B-7X-CC) is characterized by Cibicidoides pachyderma, Uvigerina spp. (Uvigerina peregrina and Uvigerina auberiana), "Globobuliminids" (including the genera Globobulimina, Praeglobobulimina, and Chilostomella), Stainforthia complanata, Valvulineria glabra, Melonis affinis, and Cassidulina carinata (Fig. F12; Table T5). These species show substantial abundance variations downhole that are likely related to changes in the quantity and quality of the organic flux or variations in sediment oxygen concentrations (Fontainer et al., 2002).

The lower interval (Sections 344-U1412B-8X-1W through 344-U1412C-6R-CC) roughly coincides with Unit II. Benthic foraminifer assemblages are substantially different from Unit I and include Globocassidulina subglobosa, Hansenisca altiformis, and two species completely absent from Unit I, Planulina renzi and Cibicidoides pachyderma var. bathyalis. The last occurrence of $P$. renzi occurs in the middle Miocene, coinciding with the first appearance of Fontbotia wuellerstorfi (van Morkhoven et al., 1986). Although these two species, present in Unit II (Table T5), are not widely used biostratigraphic markers, they help to further constrain Unit II to the Miocene. Benthic foraminifer assemblages in Unit II are characteristic of mesotrophic to oligotrophic conditions and contain a relatively high proportion of epibenthic foraminifers (e.g., Planulina and Cibicidoides), suggesting low sedimentation rates and/or high bottom currents.

Unit III benthic foraminifers differ considerably from those in Unit II but are similar to those in Unit I. 
However, given the low abundance of individuals, a comparison with Unit I was not possible (Table T5).

\section{Structural geology}

Site U1412 is located on the prism-toe of the Costa Rica margin $\sim 2.5 \mathrm{~km}$ from the frontal thrust. The primary goal at Site U1412 was to describe and document the style, geometry, and kinematics of the prism units, décollement zone, and underthrusted sediments. Hole stability issues limited recovery. In particular, Holes U1412B and U1412D yielded few structural data. Structural observations were discontinuous. We divided the structural data into two intervals corresponding to Holes U1412A and U1412B and Holes U1412C and U1412D.

\section{Holes U1412A and U1412B (0-200.3 mbsf)}

Bedding dip varies from subhorizontal to intermediate dip angles as large as $35^{\circ}$ (Fig. F13). After orienting the dip directions and dip angles into geographic coordinates, the mean bedding attitude is west-southwest, with some surfaces dipping northwest. The bedding orientation is not depth dependent. The bedding trends (NNE-SSW and southwest-northeast) are subparallel to the trench and the proximal flank of the Cocos Ridge, respectively. The combination of the trench and the subducting Cocos Ridge probably results in the two preferential orientations of the bedding planes.

Hole U1412A cores are characterized by the presence of normal faults. These structures form distinct shear planes with little displacement but well-preserved striations (Fig. F14). After orienting the dip directions, dip angles, and striations into geographic coordinates, the faults appear to form two conjugate sets with northwest-southeast and NNE-SSW trends (Fig. F15A). This data set reveals a subvertical orientation of the maximum principal stress axis, $\sigma_{1}$, and a subhorizontal, ENE-WSW orientation of the minimum principal stress axis $\sigma_{3}$ (Fig. F15B), indicating a stress regime characteristic of normal faulting. We interpret these faults to be compaction-related features. The interval where these conjugate normal faults occur ranges from 28 to 143 mbsf within lithostratigraphic Unit I. As the stratigraphic age within this interval is Pleistocene, the deduced formation age of the normal faults is younger than Pleistocene.

\section{Holes U1412C and U1412D (300-387 mbsf)}

Cores from Hole U1412C are both highly deformed and characterized by drilling disturbance. Hole U1412D was located $50 \mathrm{~m}$ trenchward of Hole U1412C, making direct correlation of the structures with Holes U1412A and U1412B difficult. Paleomagnetic orientation of the structural data is particularly difficult and cannot be provided at this time. Bedding planes measured in Hole U1412C show dip angles between $45^{\circ}$ and $65^{\circ}$ (Fig. F13). This hole is characterized by the presence of two fault zones with prominent brecciation. These fault zones are localized between 330 and 342 mbsf and 358 and 365 mbsf. The upper fault zone is located at the boundary where sedimentary age reverses from Miocene to Pleistocene (see "Paleontology and biostratigraphy"). The age reversal may be due to large accumulated displacement on the fault and suggests high activity and multiple faulting episodes. Adjacent to and within these fault zones, well-developed foliation with varying dip angles is observed (Fig. F13). Foliation is not clearly developed in Hole U1412D cores, suggesting less intense deformation. Interestingly, some normal faults similar to those present in Hole U1412A (Fig. F16) are observed in Hole U1412D and are interpreted to be compaction-related features.

Hole U1412C is additionally characterized by distinct fault planes mainly developed as reverse faults with moderately steep to steep dip angles (Fig. F13). Normal faults were also observed.

\section{Geochemistry Inorganic geochemistry}

We collected 29 APC whole-round samples $(12-25 \mathrm{~cm}$ long), 9 XCB whole-round samples $(20-25 \mathrm{~cm})$, and $10 \mathrm{RCB}$ whole-round samples $(11-37 \mathrm{~cm})$ on the catwalk at a frequency of 1-3 samples per core through Core 344-U1412A-15H and 1-2 samples per core in the XCB and RCB cored intervals of Holes U1412BU1412D. Most XCB cores were too disturbed for adequate pore fluid sampling. All samples were thoroughly cleaned for drill water contamination. The cleaned samples were placed in $\mathrm{Ti}$ squeezers and squeezed at gauge forces of $<30,000 \mathrm{lb}$. The inner diameter of the Ti squeezers is $9 \mathrm{~cm}$; thus, the maximum squeezing pressure was 3043 psi ( 21 MPa). The pore fluid was collected in syringes and passed through a $0.2 \mu \mathrm{m}$ filter prior to analysis. The volume of pore fluid recovered varied with lithology and coring technique, from 23 to $56 \mathrm{~mL}$ from the APC cores, from 0.8 to $50 \mathrm{~mL}$ from the $\mathrm{XCB}$ cores, and from 3.5 to $35 \mathrm{~mL}$ from the RCB cores. The chemical composition of the samples below the sulfate-methane transition zone (SMTZ) at 14.7 mbsf was corrected for drill fluid contamination where the sulfate data indicated contamination $<5 \%$. Specific aliquots were used for shipboard analyses, and the remaining fluid was sampled for shore-based analyses (see "Geochemistry" in the "Methods" chapter [Harris et al., 2013]). 
The uppermost three cores were processed under a nitrogen atmosphere and used for detailed studies of biogeochemical processes in the SMTZ. In addition to the $10 \mathrm{~cm}$ interstitial water samples, a $2 \mathrm{~cm}$ slice from the cleaned sediment was collected for shore-based microbiological analyses. These microbiological samples were collected through Core 344-U1412A-15H. The cleaned samples were vacuum-sealed and stored at $-80^{\circ} \mathrm{C}$.

To collect enough methane concentration data above the methane saturation depth, we sampled sediment immediately below the SMTZ at high resolution. We used real-time sulfate concentration analyses to accurately delineate the SMTZ at 14.7 mbsf. These real-time measurements allowed us to select the core sections immediately below the SMTZ (Sections 344U1412A-2H-7 and 3H-1), which were sampled on the catwalk at $20 \mathrm{~cm}$ intervals. Three headspace samples were collected from each interval for shore-based concentration and isotope analyses of the dissolved gases. Additionally, we collected one whole round just above the SMTZ depth and one below for shipboard interstitial water analyses.

In Section 344-U1412C-7R-2 we collected one whole-round sample for He isotope analysis.

The APC cores recovered from Hole U1412A do not show significant drilling contamination. In contrast, samples from Holes U1412B and U1412C were highly disturbed by drilling. Because the samples from these cores were recovered below the SMTZ, no sulfate should be present in these samples. We used the sulfate concentrations reported in Table T6 as a tracer for drilling contamination with surface seawater and corrected the pore fluid concentrations in the samples from Holes U1412B and U1412C, as described in "Geochemistry" in the "Methods" chapter (Harris et al., 2013).

Raw data for major and minor element concentrations are listed in Tables T6 and T7. In Tables T8 and T9 we list the sulfate-corrected concentration data. Sulfate-corrected data for Holes U1412A-U1412C are illustrated in Figures F17, F18, F19, and F20.

Because of drilling problems and no core recovery suitable for pore fluid analyses, all figures show a gap in data points between $\sim 200$ and $\sim 320$ mbsf.

\section{Salinity, chloride, and alkalis (sodium and potassium)}

Downhole profiles of salinity, chloride, sodium, and potassium at Site U1412 are shown in Figure F17. Salinity values slightly decrease with depth from the seawater value at the seafloor, 35 , to $\sim 30$ at the base of the hole. Chloride concentrations, however, do not vary significantly with depth. A few discrete ex- cursions to lower values between 60 and 85 mbsf are consistent with observations of moussy sediments in the cores and of a BSR and may be indicative of gas hydrate dissociation during core recovery.

Sodium concentrations remain relatively constant in the APC cores recovered from Hole U1412A. They show a marked decrease toward the sediment of lithostratigraphic Unit II to a low value of $331 \mathrm{mM}$ at 163 mbsf, which is also apparent in the low concentrations measured in the three samples collected at the bottom of this unit at 187,196 , and 329 mbsf in Hole U1412C. The decrease may be driven by volcanic tephra alteration to zeolites. Sodium concentrations increase toward the bottom of the hole but still remain lower than seawater in the deepest sample, which has a concentration of $369 \mathrm{mM}$.

There is no significant change in the concentration of potassium in the sampled depth interval. In the uppermost $\sim 100 \mathrm{~m}$, potassium concentrations are slightly higher than the seawater value of $10.5 \mathrm{mM}$ by 1-2 mM, most likely because of clay ion exchange reactions. The reason for scatter in the data points in the XCB core samples is unclear. Potassium concentrations in Hole U1412C (325-370 mbsf) are $1 \mathrm{mM}$ lower than seawater value, which may be caused by volcanic tephra alteration to clays.

\section{Alkalinity, sulfate, ammonium, phosphate, calcium, and magnesium}

Pore fluid profiles of sulfate, alkalinity, ammonium, and phosphate in the uppermost 100 to $200 \mathrm{~m}$ at this site reflect characteristic organic matter remineralization (Figs. F18, F19). Sulfate concentrations decrease almost linearly from the seafloor to the SMTZ at 14.7 mbsf. Alkalinity increases from the seawater value at the seafloor to a maximum of $44 \mathrm{mM}$ at 56 mbsf and gradually decreases with depth to $\sim 4 \mathrm{mM}$ in the deepest sediments cored at Site U1412. Alkalinity is involved in carbonate diagenesis in the uppermost $\sim 150 \mathrm{~m}$, as suggested by the Ca profile. Phosphate reaches its maximum concentration of $121 \mu \mathrm{M}$ at 23 mbsf, at a shallower depth than alkalinity, and its concentrations decrease sharply with depth, possibly because of minor apatite precipitation. Ammonium peaks at a greater depth than alkalinity and reaches a maximum value of $\sim 9.3 \mathrm{mM}$ at 111 mbsf. Ammonium concentrations show an increasing trend with depth below $\sim 300$ mbsf. However, there are not enough data points to properly interpret this trend.

$\mathrm{Ca}$ and $\mathrm{Mg}$ concentrations decrease from seawater values at the seafloor to minima of $\sim 3.9$ and $\sim 40 \mathrm{mM}$, respectively, at the SMTZ at $14.7 \mathrm{mbsf}$, reflecting precipitation of authigenic carbonates. There, however, the concentrations of both $\mathrm{Ca}$ and 
$\mathrm{Mg}$, but in particular $\mathrm{Ca}$, increase at the depth of the highest alkalinity values, and more marked increases are noted in the samples below 170 mbsf, indicating the presence of diagenetic sources for both cations. In lithostratigraphic Unit III, Ca concentrations reach a maximum value of $\sim 13 \mathrm{mM}$, slightly higher than the seawater value, suggesting a source of $\mathrm{Ca}$ at greater depth. In contrast, $\mathrm{Mg}$ concentrations decrease with depth to a minimum of $\sim 22 \mathrm{mM}$, accounting for only half of the seawater values. The inverse concentrationdepth profiles of $\mathrm{Ca}$ and $\mathrm{Mg}$ also suggest interaction with a high-temperature reaction zone at depth.

\section{Strontium, lithium, manganese, boron, silica, and barium}

Downhole distributions of $\mathrm{Sr}, \mathrm{Li}, \mathrm{Mn}, \mathrm{B}, \mathrm{Si}$, and $\mathrm{Ba}$ are shown in Figure F20. Sr concentrations remain near the seawater value of $87 \mu \mathrm{M}$ throughout Hole U1412A, with only a small incursion to low concentrations and a minimum value of $68 \mu \mathrm{M}$ at $8.8 \mathrm{mbsf}$. The overall lower concentrations in the uppermost $20 \mathrm{~m}$ are coincident with the observed decrease in calcium and suggest $\mathrm{Sr}$ uptake during carbonate precipitation. Sr in samples from Hole U1412B increases with depth, continuing toward the bottom of lithostratigraphic Unit III. The gap in data between $\sim 200$ and 320 mbsf precludes good interpretation of the diagenetic reactions responsible for the increase in $\mathrm{Sr}$ concentrations.

Li concentrations decrease in the uppermost $20 \mathrm{~m}$ from a seawater value of 25 to $5.9 \mu \mathrm{M}$ at $\sim 23 \mathrm{mbsf}$. Such a decrease in Li concentrations in the upper sediments offshore Nicoya was analyzed in the context of lithium isotope data by Chan and Kastner (2000), who interpret their results as a balance between ash alteration at low temperatures and ion exchange from clays; indeed, a rather thick ash layer is present at this depth (see "Lithostratigraphy and petrology"). In general, Li concentrations increase with depth from the minimum at $23 \mathrm{mbsf}$ to $\sim 100 \mu \mathrm{M}$ at the bottom of the cored section. These elevated values suggest interaction with a high-temperature reaction zone at depth, consistent with the calcium data.

$B$ values steadily decrease in lithostratigraphic Unit I from seawater value to $\sim 100 \mu \mathrm{M}$ at $\sim 170 \mathrm{mbsf}$, perhaps driven by volcanic tephra alteration and/or siliceous ooze diagenesis in lithostratigraphic Unit II. However, because of a lack of data this interpretation cannot be verified.

Even the shallowest samples collected in Hole U1412A show an increase in dissolved Si to $\sim 600 \mu \mathrm{M}$, a value that remains relatively constant throughout lithostratigraphic Unit I. Si concentrations are variable in Hole U1412C, ranging from 173 to $986 \mu \mathrm{M}$.
Dissolved Ba shows a marked increase in concentration below the SMTZ (Fig. F18), associated with dissolution of marine barite in environments depleted in sulfate (e.g., Torres et al., 1996). Ba concentrations remain relatively constant below $\sim 40$ mbsf and increase with depth in Holes U1412B and U1412C, suggesting a deeper source for this element.

\section{Organic geochemistry}

At Site U1412, we collected 64 samples for headspace gas, and 20 voids were also sampled for shore-based gas analyses. The data from these samples are listed in Tables T10 and T11 and plotted in Figures F21 and F22. In the headspace gas samples, methane concentrations range from 4 to $31,400 \mathrm{ppmv}$, ethane concentrations are $<12 \mathrm{ppmv}$, propane concentrations do not exceed 3 ppmv, and $\mathrm{C}_{4+}$ was not detected at all. In the void gas samples, methane concentrations range from 770,000 to $850,000 \mathrm{ppmv}$, ethane ranges between 14 and 85 ppmv, propane concentrations are $<11$ ppmv, and $\mathrm{C}_{4+}$ was not detected at any depth.

In general, methane concentrations increase rapidly below $14.1 \mathrm{mbsf}$, consistent with the depth of the SMTZ at this site (Fig. F18). The gas composition of the headspace and void gas indicates that gas originates from a biogenic source. However, the decrease with depth in the $\mathrm{C}_{1} / \mathrm{C}_{2+}$ ratios of headspace and void gas to 400 indicates a mixture of biogenic gas and thermogenic hydrocarbons that likely migrated from depth.

The organic and inorganic carbon (IC) profiles are illustrated in Figure F23 and listed in Table T12. In lithostratigraphic Unit I, total carbon fluctuates between $\sim 1.2$ and $2.9 \mathrm{wt} \%$; IC ranges from $\sim 0.1$ to $<1.2 \mathrm{wt} \%$, which corresponds to $\mathrm{CaCO}_{3}$ concentrations ranging from 0.9 to $9.6 \mathrm{wt} \%$; and total organic carbon (TOC) concentrations decrease from 1.8 to $0.8 \mathrm{wt} \%$. There is a marked change to higher values in lithostratigraphic Unit II, with IC ranging from $\sim 3$ to $8.5 \mathrm{wt} \%$, which corresponds to $\mathrm{CaCO}_{3}$ concentrations ranging from 25 to $68 \mathrm{wt} \%$ and TOC concentrations decreasing from 1.8 to $3 \mathrm{wt} \%$. In lithostratigraphic Unit III, IC ranges from 0.4 to $0.9 \mathrm{wt} \%$, which corresponds to $\mathrm{CaCO}_{3}$ concentrations ranging from 3.4 to $7.7 \mathrm{wt} \%$, and TOC concentrations are relatively constant at $\sim 1 \mathrm{wt} \%$.

Total nitrogen concentrations do not exceed $0.18 \mathrm{wt} \%$. The calculated $\mathrm{C} / \mathrm{N}$ ratio in Hole U1412A ranges between 5.4 and 15.6, suggesting that the sediment might be degraded marine organic matter. However, to fully characterize the organic carbon source we require information on the carbon isotopic ratios and other organic matter tracers. 


\section{Physical properties}

At Site U1412, physical properties measurements were made to help characterize lithostratigraphic units. After sediment cores reached thermal equilibrium with ambient temperature at $\sim 20^{\circ} \mathrm{C}$, gamma ray attenuation (GRA) density, magnetic susceptibility, and $P$-wave velocity were measured using the Whole-Round Multisensor Logger (WRMSL). After WRMSL scanning, the whole-round sections were logged for natural gamma radiation (NGR) and thermal conductivity was measured using the full-space method on unconsolidated sediments. Following core splitting, color reflectance and magnetic susceptibility were measured on the archive-half cores. Moisture and density (MAD) were measured on discrete samples collected from the working halves of the split sediment cores, generally once per section. $P$-wave velocity and strength were measured on the working halves of split cores, depending on recovered length and condition. For consolidated sediments in Hole U1412C, thermal conductivity was measured on the split core using the half-space method.

\section{Density and porosity}

Bulk density values at Site U1412 were determined from both GRA measurements on whole-round cores and mass/volume measurements on discrete samples from the working halves of split cores (see "Physical properties" in the "Methods" chapter [Harris et al., 2013]). Both types of measurements yield similar trends, but the GRA values show greater scatter. GRA values scatter higher and lower than the MAD density values in APC cores and are generally less than or equal to MAD density values for $\mathrm{XCB}$ and $\mathrm{RCB}$ cores. Gas expansion voids in Hole U1412A and variable core diameter and drilling disturbance in the $\mathrm{XCB}$ and RCB cores contribute to the scatter in GRA density values (Fig. F24). Bulk density values increase and porosity values decrease in the uppermost $30 \mathrm{~m}$. Both properties remain stable to the base of Unit I, with average bulk density and porosity values of $1.69 \mathrm{~g} / \mathrm{cm}^{3}$ and $60 \%$, respectively. In Unit I, the average grain density is $2.69 \mathrm{~g} / \mathrm{cm}^{3}$. Both the GRA and the discrete samples indicate some scattered high bulk density values in Units II and III. Just above the Unit II/III boundary, three discrete samples yielded high bulk densities and abnormally low grain densities. Limited data do not allow us to assess whether these values are real or due to measurement errors.

Bulk density and porosity values in Unit III show considerable variability but suggest slightly more compaction (higher bulk density and lower porosity) than that at the base of Unit I. Unit III samples from
Hole U1412D show porosity trends similar to those from Hole U1412C but at a slightly $(\sim 15 \mathrm{~m})$ shallower depth.

\section{Magnetic susceptibility}

Volumetric magnetic susceptibilities were measured using the WRMSL, and point measurements were made on the SHMSL for all core sections longer than $\sim 20 \mathrm{~cm}$ at Site U1412 (Fig. F25). Magnetic susceptibility values measured by these two methods are in good agreement. In Unit I, the background magnetic susceptibility is between 20 and 30 IU. Magnetic susceptibility excursions reach $\sim 200$ IU and are sometimes, but not always, associated with tephra layers. The few recovered intervals in Unit II yielded low magnetic susceptibility values ( $<15 \mathrm{IU})$. Magnetic susceptibility in Unit III is variable, ranging from near 0 to $\sim 75 \mathrm{IU}$ with one excursion to $>160 \mathrm{IU}$.

\section{Natural gamma radiation}

NGR counting periods were $10 \mathrm{~min}$, and measurement spacing was fixed at $20 \mathrm{~cm}$ for all holes and sections. NGR results are reported in counts per second (cps) (Fig. F26). NGR values in Unit I generally range between 15 and 25 cps. Lower NGR values (around 10 cps) are observed within Unit II. NGR values in Unit III are higher and have greater variability than those within Units I and II. The highest counts, around 46 cps, were observed within Unit III at 362 mbsf.

\section{$P$-wave velocity}

$P$-wave velocity at Site U1412 was measured on the working halves of cores using the $P$-wave caliper (Fig. F27). Because of gas expansion, poor recovery, and drilling disturbance, $P$-wave velocity data could only be collected from limited intervals. In the uppermost 25 mbsf of Unit I, $P$-wave velocities vary between 1520 and $1600 \mathrm{~m} / \mathrm{s}$. From 330 mbsf, just above the boundary between Units II and III, to the bottom of Unit III, $P$-wave velocity shows scattered values around $1500 \pm 200 \mathrm{~m} / \mathrm{s}$.

\section{Thermal conductivity}

Thermal conductivity measurements were conducted on sediment whole-round cores using the needleprobe method and on lithified split cores using the half-space method (see "Physical properties" in the "Methods" chapter [Harris et al., 2013]). Thermal conductivity values within Unit I range from 0.7 to $1.2 \mathrm{~W} /(\mathrm{m} \cdot \mathrm{K})$, with most values between 0.9 and $1 \mathrm{~W} /(\mathrm{m} \cdot \mathrm{K})$. Thermal conductivity values decrease slightly with depth, possibly because of gas disturbance of the core (Fig. F28A). This trend contradicts 
the commonly observed inverse correlation with porosity, which is nearly constant within Unit I (Fig. F24). However, thermal conductivities are higher in Unit III compared to Unit I, following the inverse relationship with porosity. Thermal conductivity values within Unit III are higher than those within Unit I, and they rapidly increase with depth from 1 to $1.20 \mathrm{~W} /(\mathrm{m} \cdot \mathrm{K})$.

\section{Downhole temperature and heat flow}

Four downhole temperature measurements were attempted using the APCT- 3 between 20 and 60 mbsf in Hole U1412A. All measurements were made in a calm sea state. A least-squares linear fit to the temperature data yields a gradient of $114^{\circ} \mathrm{C} / \mathrm{km}$ and a bottom water temperature of $2.25^{\circ} \mathrm{C}$ (Fig. F28B). The use of a linear fit implies constant thermal conductivity and basal heat flow. Extrapolation of temperature to the base of the hole was not conducted because of the lack of reliable thermal conductivity values within Unit II.

\section{Sediment strength}

Compressive sediment strength was measured by the Geotester STCL-5 pocket penetrometer in Units I and II and by a third-party needle penetrometer in Units II and III (see "Physical properties" in the "Methods" chapter [Harris et al., 2013]). Shear strength in Unit I was measured by the automated vane shear apparatus. In the uppermost $30 \mathrm{~m}$, compressive strength linearly increases with depth from $\sim 2$ to $390 \mathrm{kPa}$ and shear strength increases from 20 to $\sim 180 \mathrm{kPa}$ (Fig. F29). From $\sim 30$ to $\sim 180 \mathrm{mbsf}$, compressive strength values become variable, ranging between $\sim 100$ and $\sim 470 \mathrm{kPa}$, and strength does not increase with depth. Values in Unit III are very scattered. The highest strength of $1980 \mathrm{kPa}$ was observed at $\sim 330$ mbsf, where the lowest porosity $(\sim 30 \%)$ was observed (Fig. F24). Some of the scatter in compressive strength below 30 mbsf may reflect variable disturbance from gas expansion in Unit I and from the small surface area tested by the needle penetrometer.

\section{Electrical conductivity and formation factor}

Formation factor was obtained from electrical conductivity measurements in the $y$ - and $z$-axes of the split core from the shallow portion of Hole U1412A (0 to $~ 107.91 \mathrm{mbsf}$ ) and in the $z$-axis in Hole U1412B (0.1 6.25 mbsf) (Fig. F30). The $y$ and $z$ measurements in Hole U1412A are similar throughout the hole, indicating little anisotropy of electrical conductivity within the sediments. Formation factor increases from 1.5 to 3.2 between 0 and 14 mbsf and becomes stable between 14 and $~ 65$ mbsf, ranging between 2.5 and 4.0. Between $\sim 65$ and 107.91 mbsf, formation factor decreases with depth. Core disturbance due to gas expansion likely causes some of the observed scatter.

\section{Color spectrophotometry}

Reflectance $L^{*}$ values range between 30 and 40 and are similar in Units I and III, whereas reflectance $a^{*}$ and reflectance $b^{*}$ values show a slight shift at 20 mbsf and excursions just below the Unit II/III boundary (Fig. F31).

\section{Paleomagnetism}

Four holes were drilled at Site U1412. Cores 344U1412A-1H through $15 \mathrm{H}$ were cored with the APC using nonmagnetic core barrels and oriented with the FlexIT orientation tool. Cores 344-U1412A-16X through $25 \mathrm{X}$ were cored with the XCB system. Core 344-U1412B-1H was also cored with the APC, and Cores 344-U1412B-3X through 20X were cored with the XCB. Core 344-U1412B-21 was a drilled interval. Cores 344-U1412C-2R through 7R and 344-U1412D$1 \mathrm{R}$ through $3 \mathrm{R}$ were cored with the RCB. We measured the remanent magnetization of archive section halves from Cores 344-U1412A-1H through 23X, Core 344-U1412B-1H through Section 11X-1, Sections 344-U1412C-5R-2 through 9R-3, and Sections 344-U1412D-2R-1 through 3R-5. In order to isolate the characteristic remanent magnetization (ChRM), these archive section halves were demagnetized in an alternating field (AF) up to $40 \mathrm{mT}$ and measured with the pass-through superconducting rock magnetometer (SRM) at $2.5 \mathrm{~cm}$ intervals. The remaining core sections were not measured because of the poor conditions of the recovered material. In order to verify the section data, we demagnetized 61 discrete samples using progressive AF and thermal demagnetization techniques and measured them in the SRM.

\section{Natural remanent magnetization of cores}

Downhole variations of paleomagnetic data obtained at Site U1412 are shown in Figures F32, F33, F34, and F35. The natural remanent magnetization (NRM) intensity for the carbonaceous silty clay to clayey silt of Unit I (204.74-338.50 mbsf; see "Lithostratigraphy and petrology") is on the order of $10^{-2} \mathrm{~A} / \mathrm{m}$ (Figs. F32, F33). The clayey siltstone of Unit III (338.50-387.00 mbsf) has somewhat lower NRM intensity (on the order of $10^{-3} \mathrm{~A} / \mathrm{m}$; Fig. F34). The calcareous ooze with nannofossils and diatoms of Unit II (204.74-338.50 mbsf) has the lowest NRM intensity (on the order of $10^{-4} \mathrm{~A} / \mathrm{m}$; Fig. F34). Sediments recovered from Hole U1412D have a mean 
NRM intensity of $2.5 \times 10^{-3} \mathrm{~A} / \mathrm{m}$ (Fig. F35). There are more significant variations in NRM intensity in lithostratigraphic Unit I than in Units II and III. We observed a strong correlation between the variations in magnetic susceptibility and the variations in NRM intensity (see "Physical properties").

A few troughs of lower NRM values appear around $\sim 12$ and $\sim 146$ mbsf in Unit I (Fig. F32); these troughs can be linked directly to the presence of watery sediments in these intervals and are likely due to drilling disturbances. NRM measurements of discrete samples taken from the nonwatery sediments above and below these intervals (block crosses in Fig. F32) show intensity values that are similar to the section data, confirming that the watery sediments indeed caused the lower NRM troughs in the pass-through records.

\section{Magnetic noise in the SRM and $y$-axis flux jumps}

During initial drilling operations at Site U1412, we observed a large increase in the frequency and number of magnetic flux jumps in the $y$-axis superconducting quantum interference device (SQUID). These jumps produced large magnetic noise anomalies and adversely affected the measurements of some sections (see the uniform inclination values at the top of Fig. F33). Discussions with IODP staff helped us find the solution for this anomaly. This magnetic noise is mainly due to the so-called "antenna" effect described originally by Gary Acton and others in the "Assessment of Readiness of the Refurbished D/V JOIDES Resolution" (scientific.oceandrilling.org/ xmlui/handle/10914/20521/) and most recently by the Expedition 342 scientists (see "Paleomagnetism" in Norris et al., in press). These reports led us to discover that there was a tiny interval $(\sim 0.2 \mathrm{~cm})$ between the aluminum foil wrapped on the cable attached to the in-line degausser and the magnetic shielding assembly. The aluminum foil was used to prevent an ambient electromagnetic field (EMF) from interfering with the SRM, but the tiny gap allowed the EMF to be transmitted inside the SRM. Core sections (especially full $1.5 \mathrm{~m}$ length sections) acted like an antenna or wire that conducts the EMF along its length to the SQUID sensors, in a process termed radio-frequency magnetic induction. We rewrapped the power cable attached to the in-line degausser with new aluminum foil and taped the foil to the shielding assembly to make sure the foil was electrically grounded. The magnetic noise decreased immediately, and no major flux jumps were noticed after this grounding. Nevertheless, small flux jumps still exist and are believed to be caused by random disturbances from wiring in the laboratory and fluctuations in ship's power during heavy operations on the rig floor. At present, we cannot prevent this kind of magnetic noise except by repeating the measurement where the small flux jumps occurred. In most cases, the repeated measurements were improved and free of the flux jumps.

\section{Paleomagnetic demagnetization results}

As with cores recovered from other Expedition 344 sites, remagnetization imparted by the coring process is common. NRM inclinations are strongly biased toward the vertical (mostly toward $+90^{\circ}$ ) in a majority of cores. Upon AF demagnetization to $40 \mathrm{mT}$, a significant decrease in intensity (about an order of magnitude; Fig. F32) and a shift of inclination toward shallower values were observed. The inclinations from APC cores (at depths shallower than $108 \mathrm{mbsf}$ ) come close to the expected timeaveraged geomagnetic field inclination at this site (approximately $\pm 18^{\circ}$ ), whereas the inclinations from $\mathrm{XCB}$ cores remain much steeper $\left(\sim 50^{\circ}-60^{\circ}\right)$. It is clear that the maximum level of AF demagnetization (40 mT) we applied was not enough to remove the overprints entirely. An example of good-quality AF demagnetization results is shown in Figure F36.

We demagnetized 61 discrete samples (43 from Hole U1412A, 9 from Hole U1412B, 7 from Hole U1412C, and 2 from Hole U1412D), using stepwise AF and thermal demagnetization (Figs. F32, F33, F34, F35). After removal of the drilling-induced component, the ChRMs of both normal and reversed polarities were observed for most of the samples (Fig. F34). A pair of sister samples was treated by AF and thermal demagnetization. The AF demagnetized sample displayed high resistance to AF demagnetization to $120 \mathrm{mT}$, and the thermally demagnetized sample showed unblocking temperature between $650^{\circ}$ and $675^{\circ} \mathrm{C}$, indicating that the main magnetic carrier (probably hematite) in this sample has a high Curie temperature and high coercivity. ChRM inclinations of discrete samples obtained from principal component analysis (PCA; Kirschvink, 1980) for the four holes are plotted in Figures F32, F33, F34, and F35.

\section{Implications for magnetostratigraphy}

We used ChRM inclinations and declinations from both discrete and pass-through measurements to define magnetic polarity sequences (Fig. F37). We recognize seven magnetozones in Hole U1412A. These magnetozones are defined as intervals with multiple consecutive samples with polarities that are distinctly different from neighboring intervals. The upper part of Hole U1412A is characterized by two reversed zones (R1 and R2) and three normal polarity zones (N1, N2, and N3). The lower part of the hole is characterized by one long normal interval (N4) and 
one reversed interval (R3). Shipboard micropaleontological studies indicate that the base of Hole U1412A (Core 344-U1412A-17X) is close to the Zone NN19/ NN18 boundary $(\sim 1.9 \mathrm{Ma})$, the middle part of the hole $($ Core $6 \mathrm{H})$ is younger than $1.3 \mathrm{Ma}$, and the uppermost two cores (Cores $1 \mathrm{H}$ and $2 \mathrm{H}$ ) may be within Zone NN21 (younger than 0.29 Ma) (see "Paleontology and biostratigraphy"). Using these age points as a guide to correlate the observed magnetozones with those in the Gradstein et al. (2012) geomagnetic polarity timescale, we interpreted $\mathrm{N} 1$ as the upper part of the Brunhes Chron and N2 and N3 as the Jaramillo and Cobb Mountain Subchrons, respectively. Consequently, the long normally magnetized Zone N4 is likely the Olduvai Subchron (1.788-1.945 Ma) with its upper boundary placed at $\sim 92 \mathrm{mbsf}$ (Fig. F37). If true, this would suggest extremely high sediment accumulation rates for Hole U1412A, similar to those in Hole U1379C. Shore-based radiometric dating on tephra layers within Unit I (i.e., 25 and 95 mbsf; Fig. F32) will provide an independent check on the age assignments based on magnetostratigraphic and biostratigraphic results.

Paleomagnetic measurements of nine discrete samples from Hole U1412B display a change from normal to reversed polarity at $\sim 167$ mbsf (Fig. F33). Changes in inclination sign are also observed for the seven samples studied from Hole U1412C (Fig. F34). Two discrete samples from Hole U1412D were measured for shipboard structural analyses (Fig. F35). Because of the small number of samples, we have no magnetostratigraphic interpretations at this time. Shore-based integrated work with micropaleontological data and paleomagnetic studies of discrete samples from each hole are required to estimate the timing and origin of the magnetization recorded by the sediments at Site U1412.

\section{References}

Chan, L.-H., and Kastner, M., 2000. Lithium isotopic compositions of pore fluids and sediments in the Costa Rica subduction zone: implications for fluid processes and sediment contribution to the arc volcanoes. Earth Planet. Sci. Lett., 183(1-2):275-290. doi:10.1016/S0012821X(00)00275-2

Fontanier, C., Jorissen, F.J., Licari, L., Alexandre, A., Anschutz, P., and Carbonel, P., 2002. Live benthic foraminiferal faunas from the Bay of Biscay: faunal density, composition, and microhabitats. Deep-Sea Res., Part I, 49(4):751-785. doi:10.1016/S0967-0637(01)00078-4
Gradstein, F.M., Ogg, J.G., Schmitz, M.D., and Ogg, G.M. (Eds)., 2012. The Geological Time Scale 2012: Amsterdam (Elsevier).

Harris, R.N., Sakaguchi, A., Petronotis, K., Baxter, A.T., Berg, R., Burkett, A., Charpentier, D., Choi, J., Diz Ferreiro, P., Hamahashi, M., Hashimoto, Y., Heydolph, K., Jovane, L., Kastner, M., Kurz, W., Kutterolf, S.O., Li, Y., Malinverno, A., Martin, K.M., Millan, C., Nascimento, D.B., Saito, S., Sandoval Gutierrez, M.I., Screaton, E.J., Smith-Duque, C.E., Solomon, E.A., Straub, S.M., Tanikawa, W., Torres, M.E., Uchimura, H., Vannucchi, P., Yamamoto, Y., Yan, Q., and Zhao, X., 2013. Methods. In Harris, R.N., Sakaguchi, A., Petronotis, K., and the Expedition 344 Scientists, Proc. IODP, 344: College Station, TX (Integrated Ocean Drilling Program). doi:10.2204/ iodp.proc.344.102.2013

Kamikuri, S., Motoyama, I., Nishi, H., and Iwai, M., 2009. Neogene radiolarian biostratigraphy and faunal evolution rates in the eastern equatorial Pacific ODP Sites 845 and 1241. Acta Palaeontol. Pol., 54(4):713-742. doi:10.4202/app.2008.0076

Kirschvink, J.L., 1980. The least-squares line and plane and the analysis of palaeomagnetic data. Geophys. J. R. Astron. Soc., 62(3):699-718. doi:10.1111/j.1365246X.1980.tb02601.x

Norris, R.D., Wilson, P.A., Blum, P., Fehr, A., Agnini, C., Bornemann, A., Boulila, S., Bown, P.R., Cournede, C., Friedrich, O., Ghosh, A.K., Hollis, C.J., Hull, P.M., Jo, K., Junium, C.K., Kaneko, M., Liebrand, D., Lippert, P.C., Liu, Z., Matsui, H., Moriya, K., Nishi, H., Opdyke, B.N., Penman, D., Romans, B., Scher, H.D., Sexton, P., Takagi, H., Turner, S.K., Whiteside, J.H., Yamaguchi, T., and Yamamoto, Y., in press. Site U1405. In Norris, R.D., Wilson, P.A., Blum, P., and the Expedition 342 Scientists, Proc. IODP, 342: College Station, TX (Integrated Ocean Drilling Program). doi:10.2204/iodp.proc.342.106.2014

Sanfilippo, A., and Nigrini, C., 1998. Code numbers for Cenozoic low latitude radiolarian biostratigraphic zones and GPTS conversion tables. Mar. Micropaleontol., 33(12):109-117, 121-156. doi:10.1016/S03778398(97)00030-3

Torres, M.E., Bohrmann, G., and Suess, E., 1996. Authigenic barites and fluxes of barium associated with fluid seeps in the Peru subduction zone. Earth Planet. Sci. Lett., 144(34):469-481. doi:10.1016/S0012-821X(96)00163-X

van Morkhoven, F.P.C.M., Berggren, W.A., Edwards, A.S., and Oertli, H.J., 1986. Cenozoic cosmopolitan deepwater benthic foraminifera. Bull. Cent. Rech. Explor.Prod. Elf-Aquitaine, 11.

Zijderveld, J.D.A., 1967. AC demagnetization of rocks: analysis of results. In Collinson, D.W., Creer, K.M., and Runcorn, S.K. (Eds.), Methods in Palaeomagnetism: Amsterdam (Elsevier), 254-286.

Publication: 11 December 2013 MS 344-105 
Figure F1. Detail of poststack time-migrated seismic Line BGR99-7 centered at Site U1412. Prestack depth migration from C.R. Ranero (unpubl. data). BSR = bottom-simulating reflector.

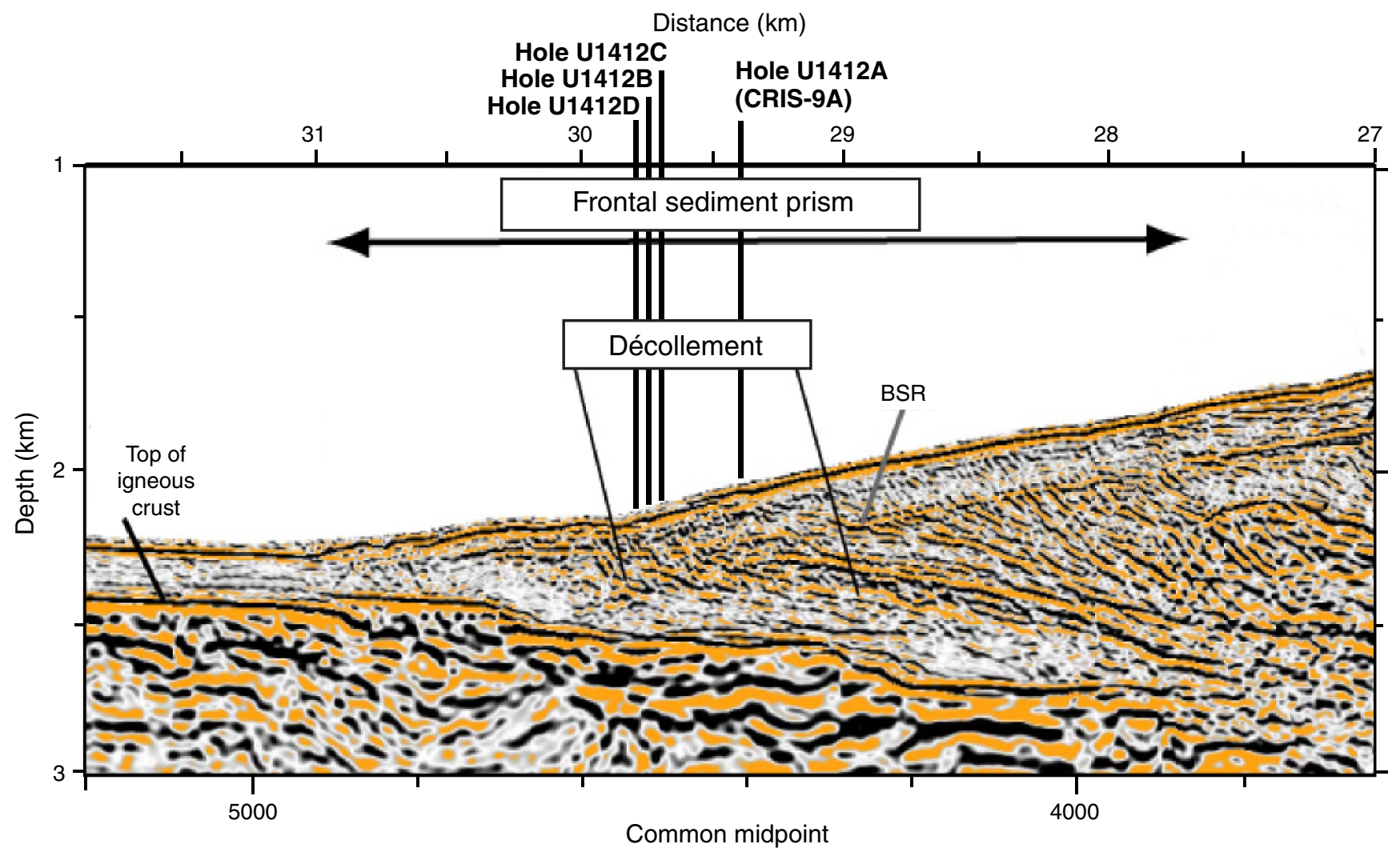


Figure F2. Location of Expedition 344 drill sites. Red diamonds denote Expedition 344 sites (U1380, U1381, and U1412-U1414), and yellow diamonds denote Expedition 334 sites not occupied during Expedition 344 (U1378, U1379). Red lines = 3-D seismic survey, black lines = seismic reflection lines. Numbers along the short and long axes of the 3-D survey represent inlines and crosslines, respectively.

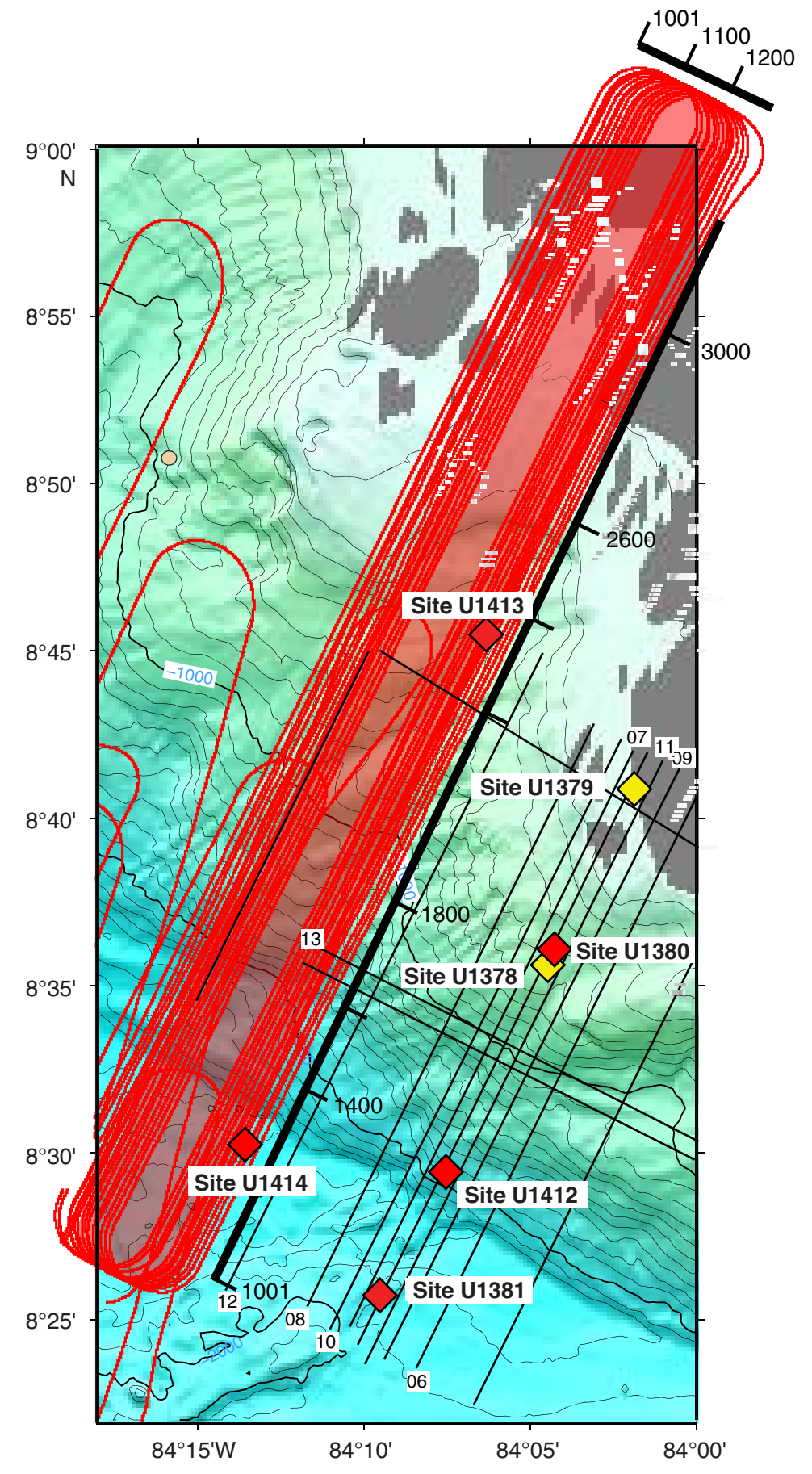


Figure F3. Lithostratigraphic summary of Site U1412.

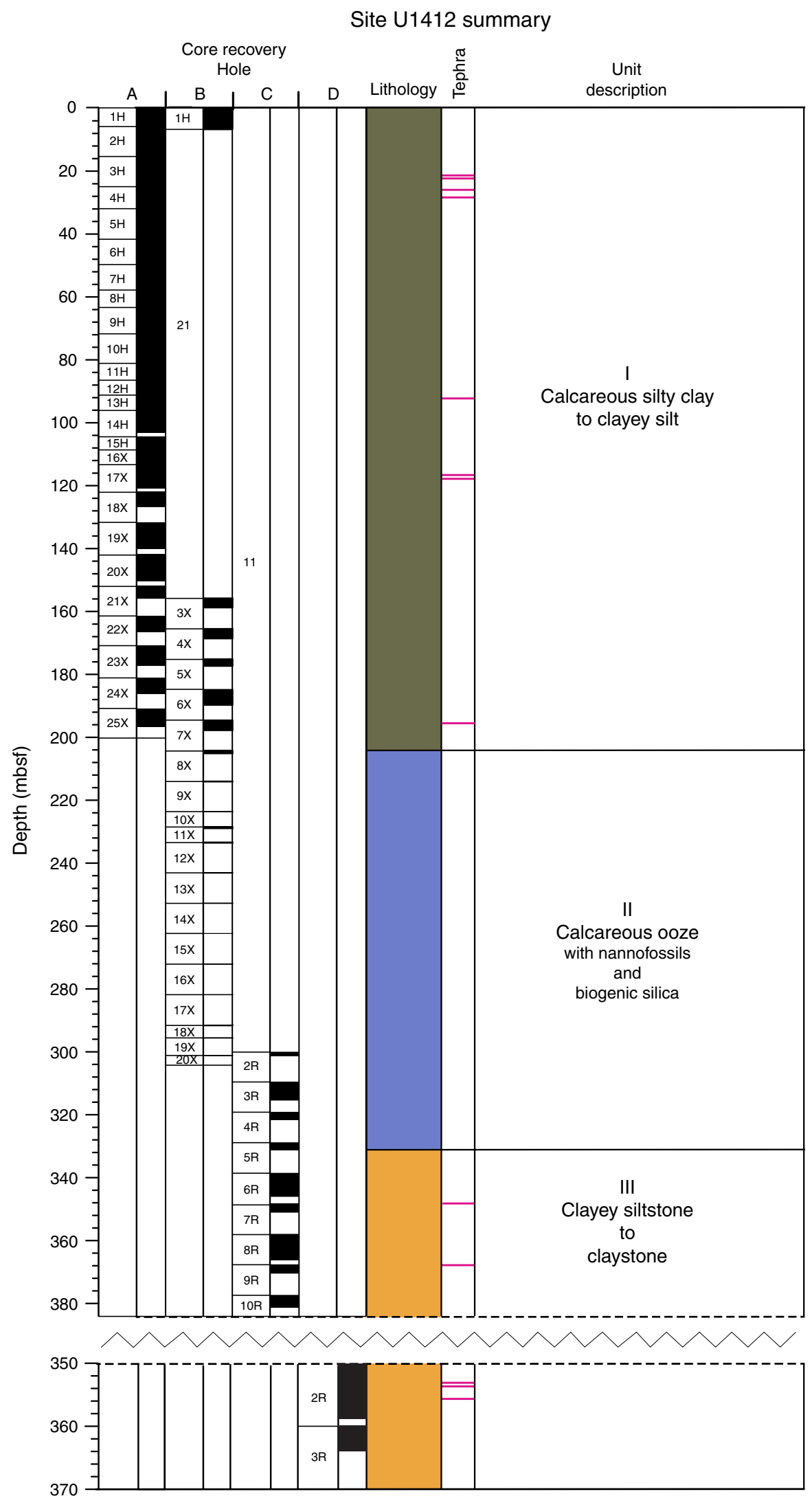


Figure F4. Digital image of dark greenish gray clay lithology representative of Unit I (interval 344-U1412A-2H$6 \mathrm{~A}, 32-44 \mathrm{~cm}$ ). Note the small (millimeter size) pods filled with sponge spicules widely disseminated throughout the unit.

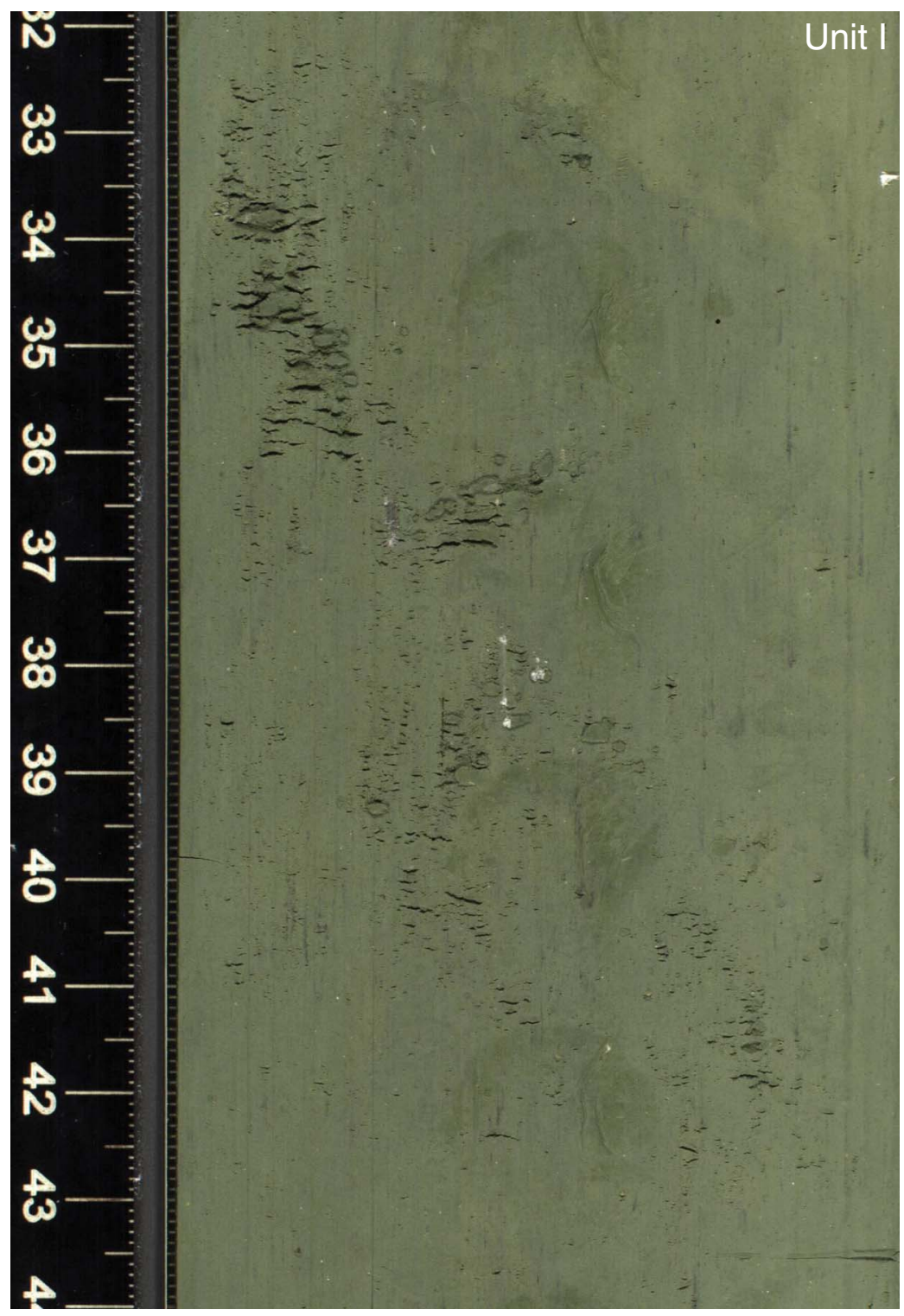


Figure F5. Digital image of one of the dark greenish gray tephra layers intercalated throughout the Unit I sediment (interval 344-U1412A-17X-3A, 40-61 cm). Note the sharp to gradational upper contact and the sharp lower contact, characteristic of the tephras in this unit.

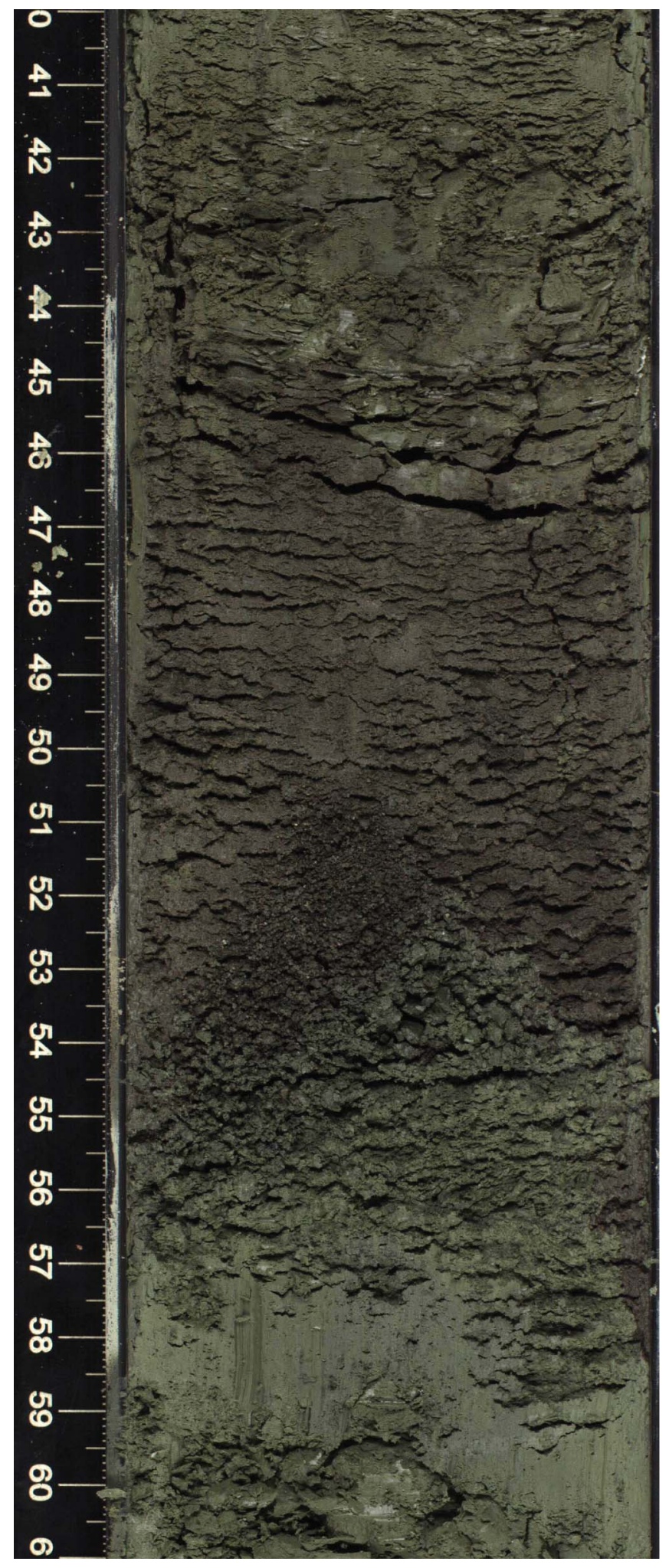


Figure F6. Digital image of glauconite-rich layer (interval 344-U1412A-2H-1A, 70-89 cm).

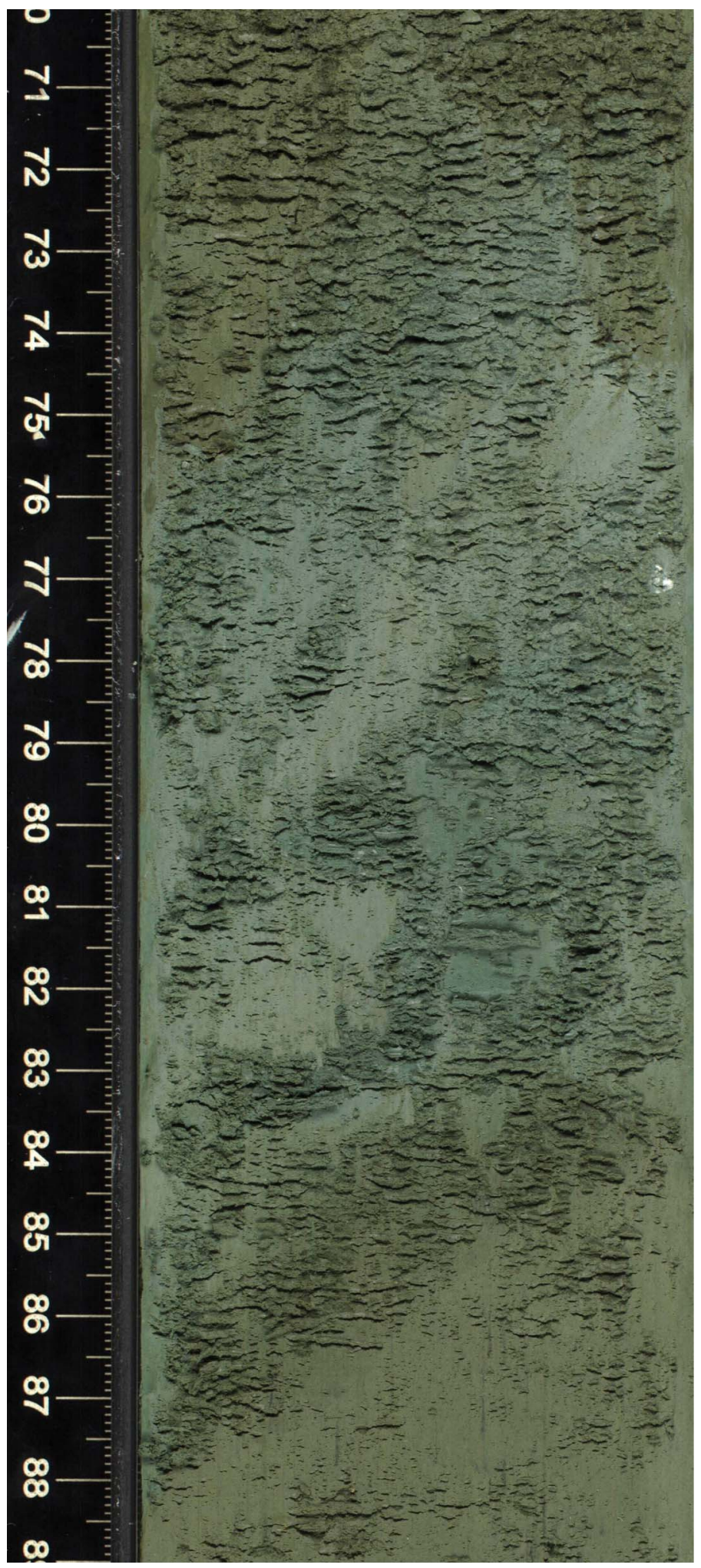


Figure F7. Digital image of the boundary between Unit I and Unit II with a thin glauconite layer marking the transition (interval 344-U1412B-8X-1A, 36-75 cm).

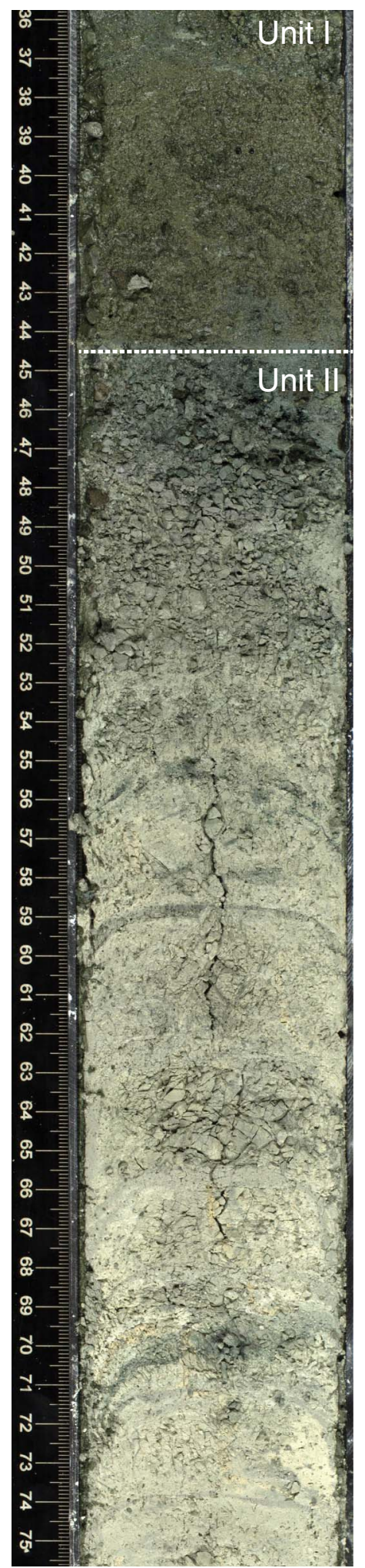


Figure F8. Digital image of light grayish brown diatomaceous ooze from the top of Unit II, which gives way to the darker grayish brown nannofossil ooze that dominates the unit (interval 344-U1412B-8X-CCA, 0-32 cm).

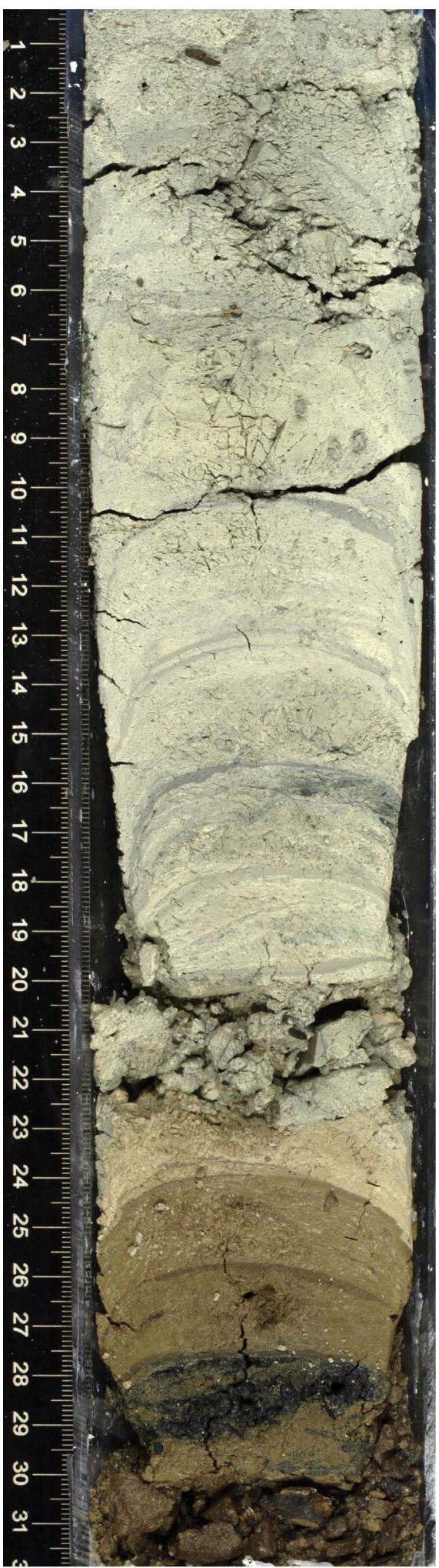


Figure F9. Digital image of well-consolidated calcareous clayey siltstone that characterizes Unit III (interval 344-U1412C-5R-3A, 49-69 cm). Note the dark brown reworked sedimentary lithic fragments.

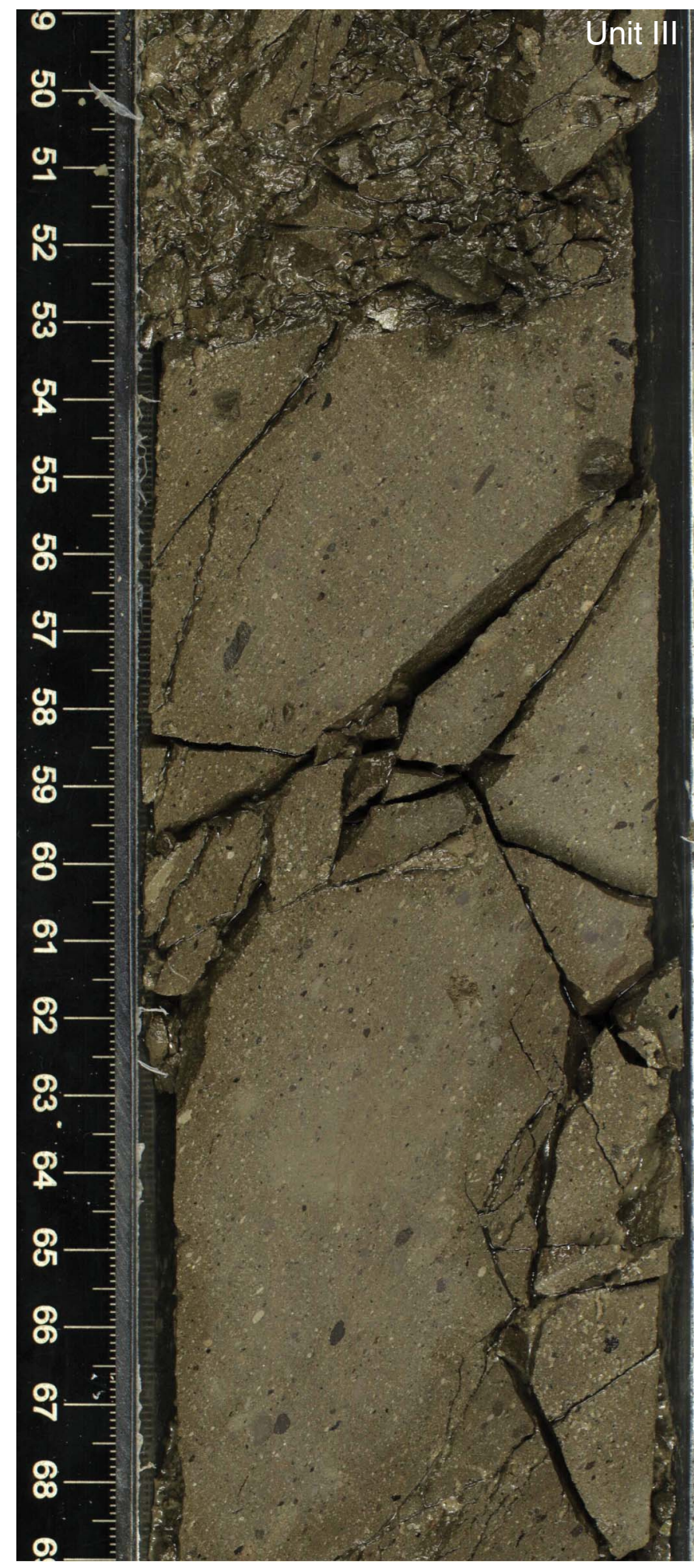


Figure F10. Digital image of sharp, irregular contact between greenish clayey siltstone (top) and a well-consolidated dark gray tephra layer (bottom) in the highly bioturbated Unit III (interval 344-U1412C-9R-2A, 0-17 cm).

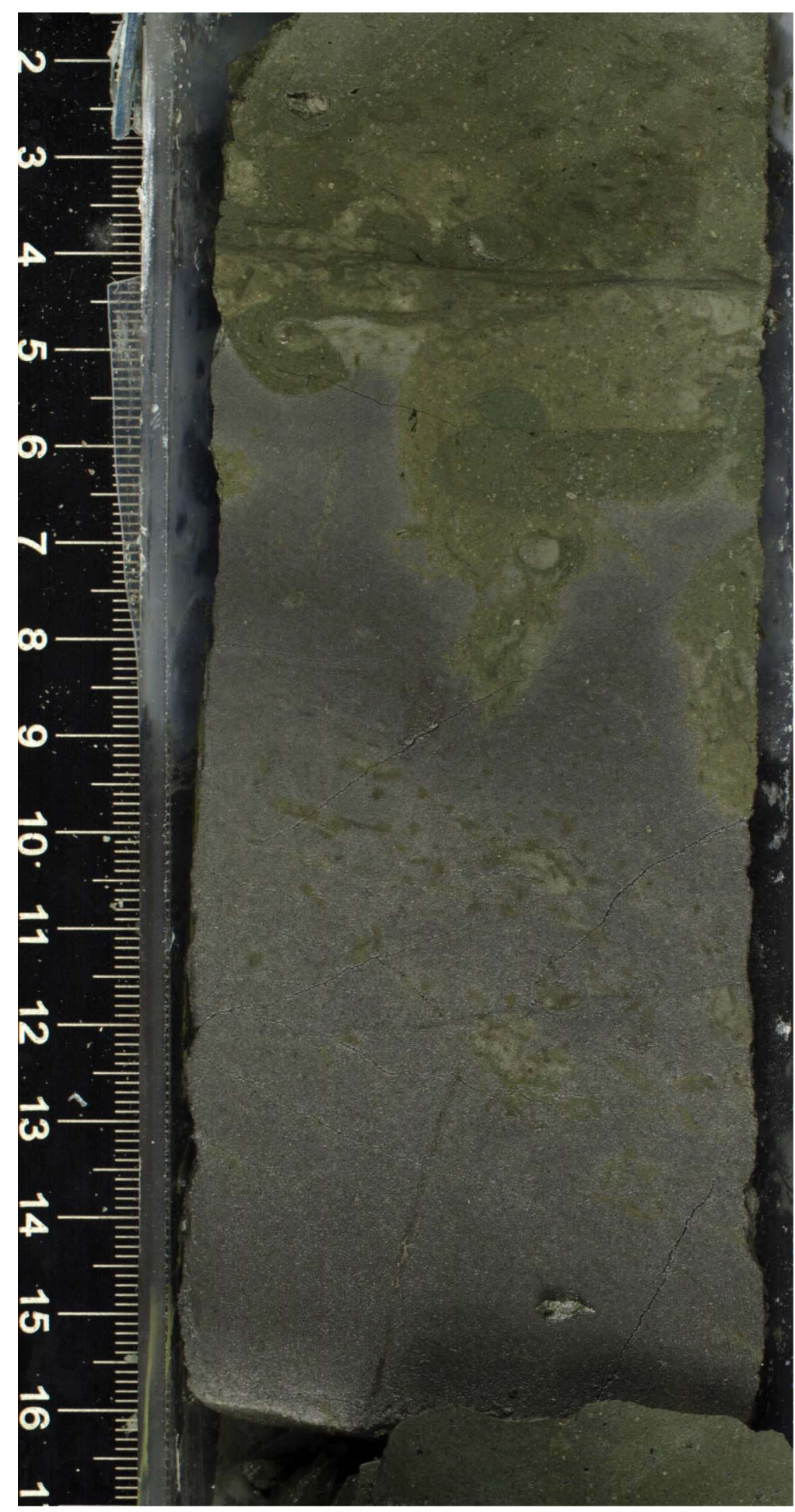


Figure F11. Typical XRD patterns obtained for bulk rock samples, Site U1412. A = analcime, C = calcite, Chl = chlorite (clinochlore), $\mathrm{D}=$ dolomite, $\mathrm{H}=$ heulandite, $\mathrm{Ha}=$ halite, $\mathrm{Ho}=$ hornblende, $\mathrm{L}=$ laumontite, $\mathrm{P}=$ plagioclase, $\mathrm{Py}=$ pyrite, $\mathrm{Q}=$ quartz, $\mathrm{S}=$ smectite.
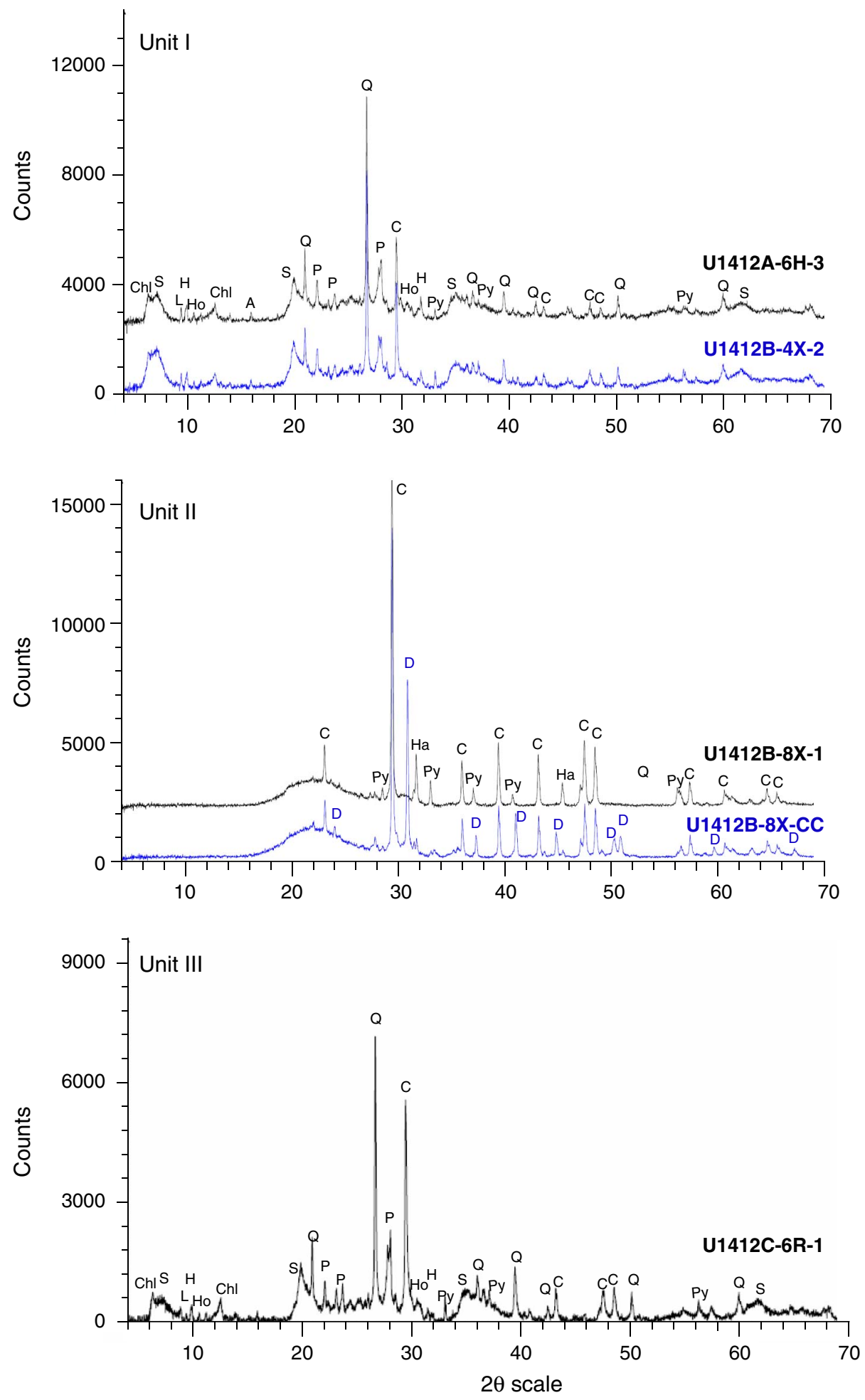
Figure F12. Relative abundance of the most characteristic benthic foraminifer assemblages at Site U1412. Samples containing $<100$ individuals per sample were not used for relative abundance calculations. Uvigerina spp. includes Uvigerina peregrina and Uvigerina auberiana, and the Globobuliminids group includes Globobulimina spp., Globobulimina affinis, Globobulimina auriculata, Chilostomella oolina, Praeglobobulimina spinescens, and Praeglobobulimina ovata.
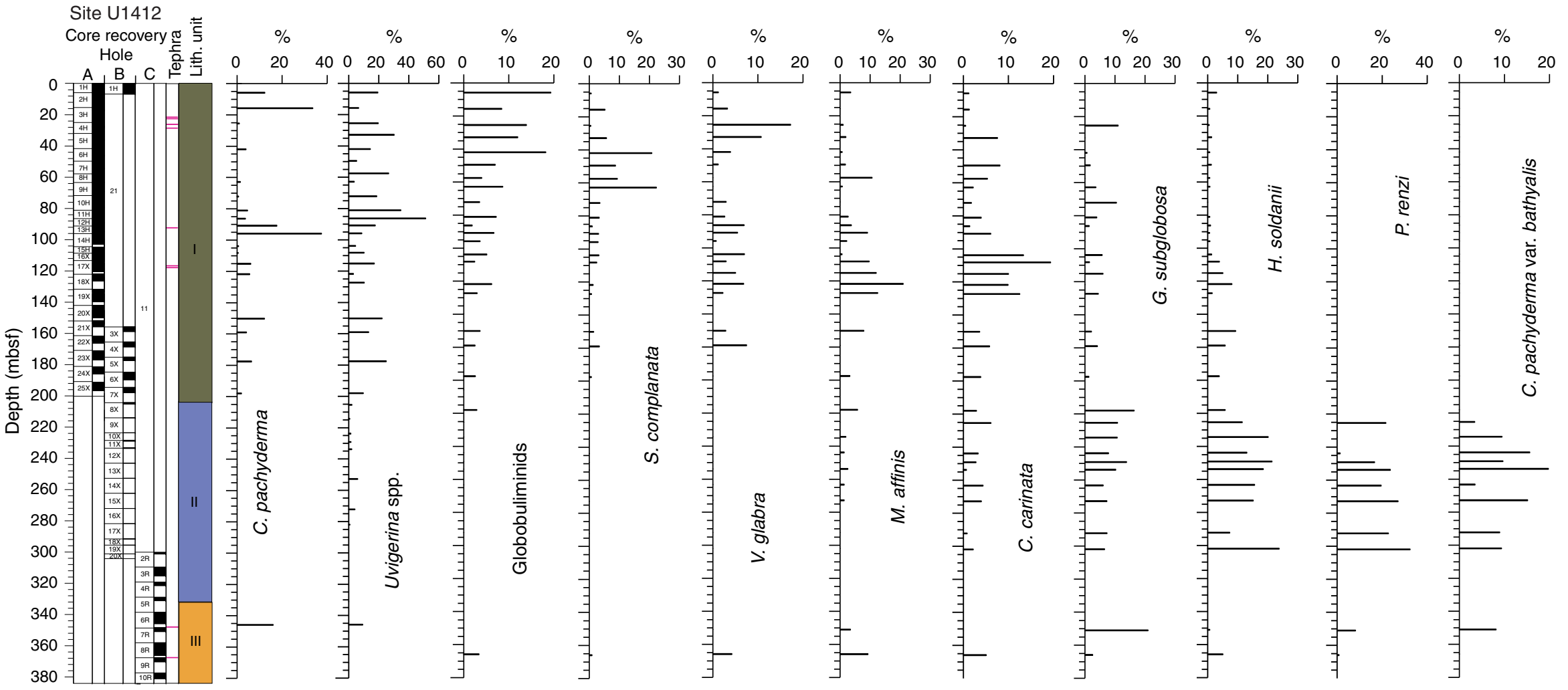
Figure F13. Plot of bedding dip angles, dip angles of faults, and other fractures as a function of depth, Site U1412. Purple bands across the figure indicate breccia/fracture zones.

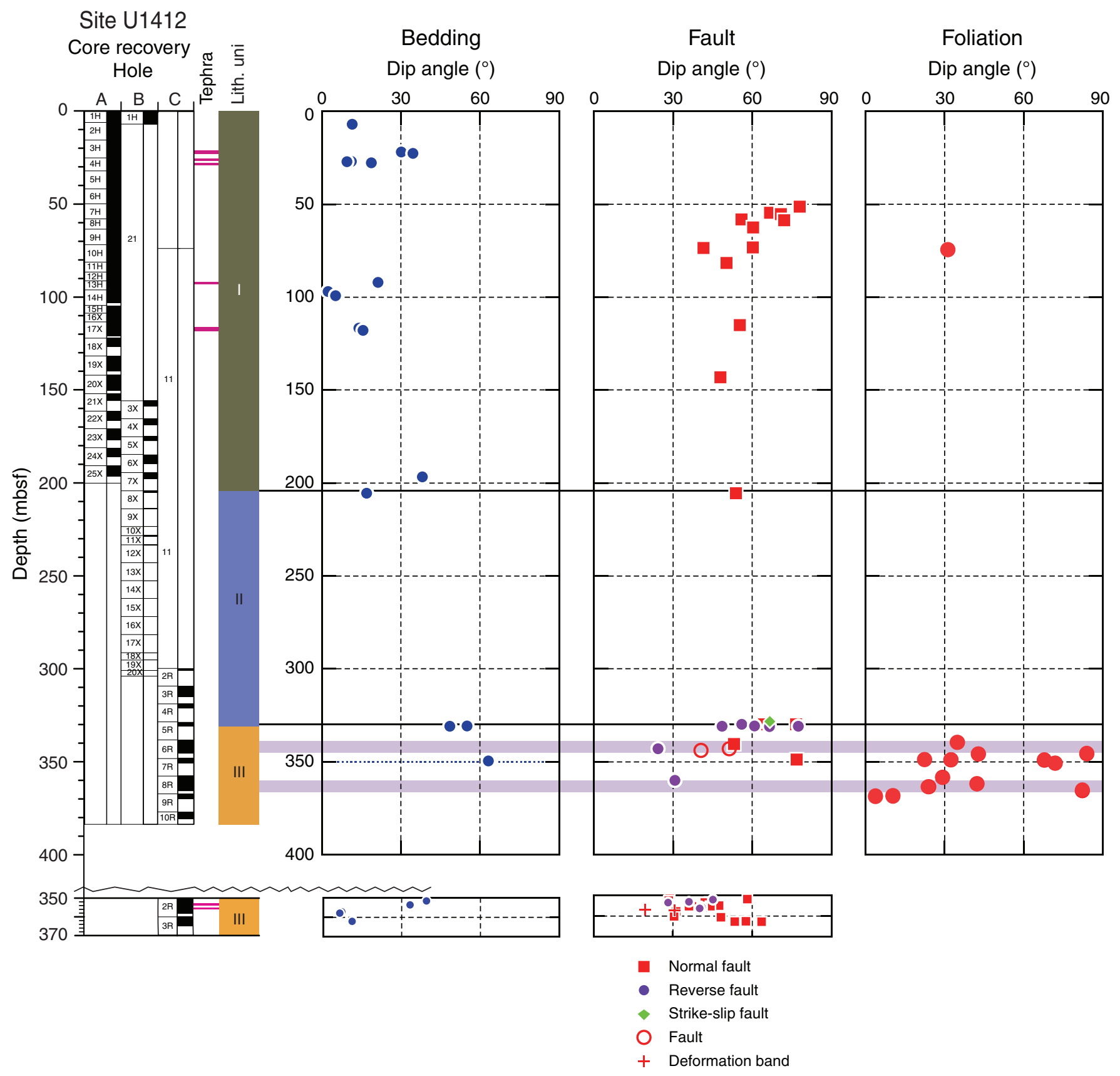


Figure F14. Stereographic diagram showing the orientation of bedding planes, Hole U1412A.

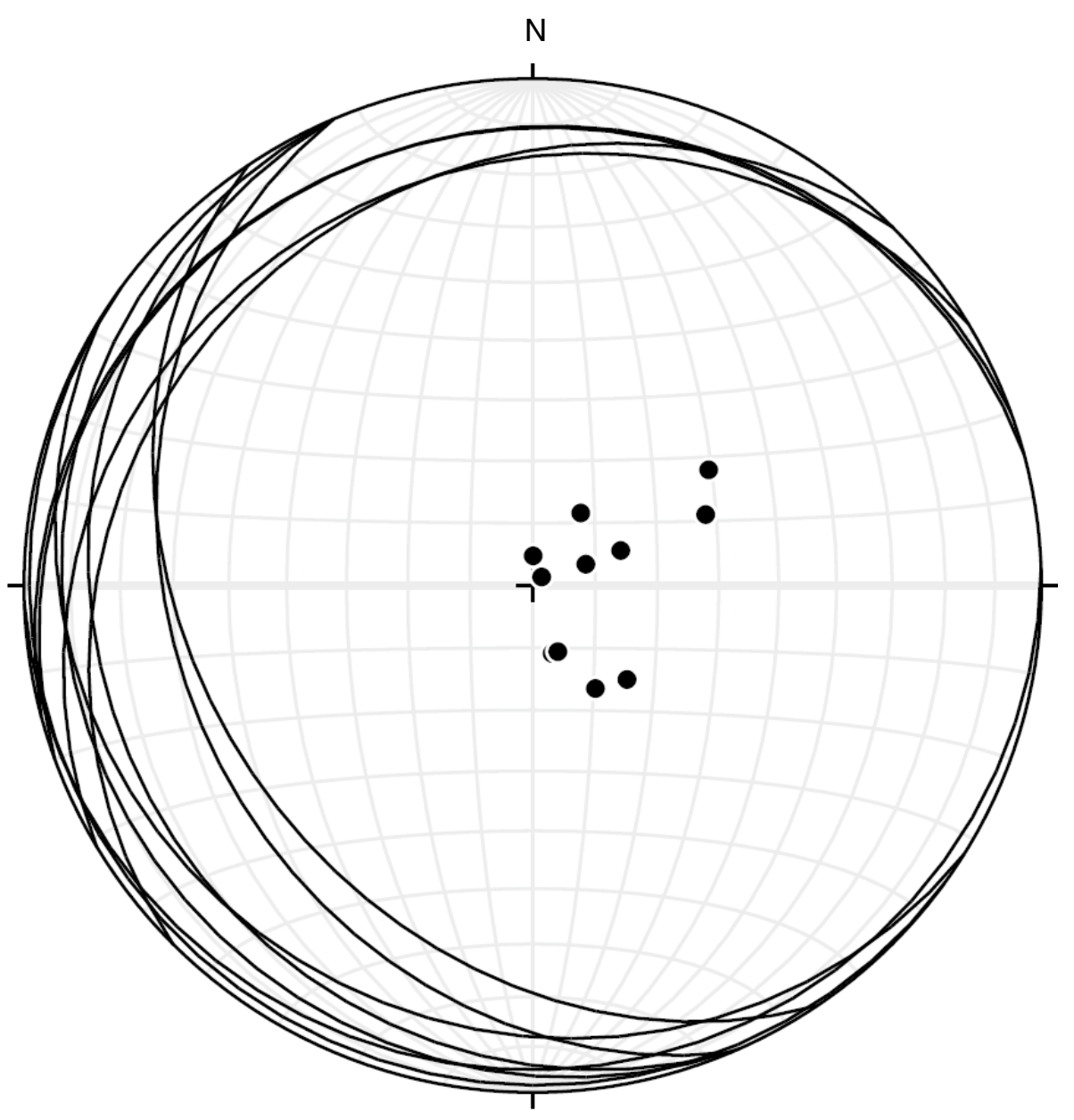


Figure F15. Stereographic diagrams showing (A) normal fault planes and lineations and (B) fault kinematics analysis, along with related orientation of principal stress axes, Hole U1412A.
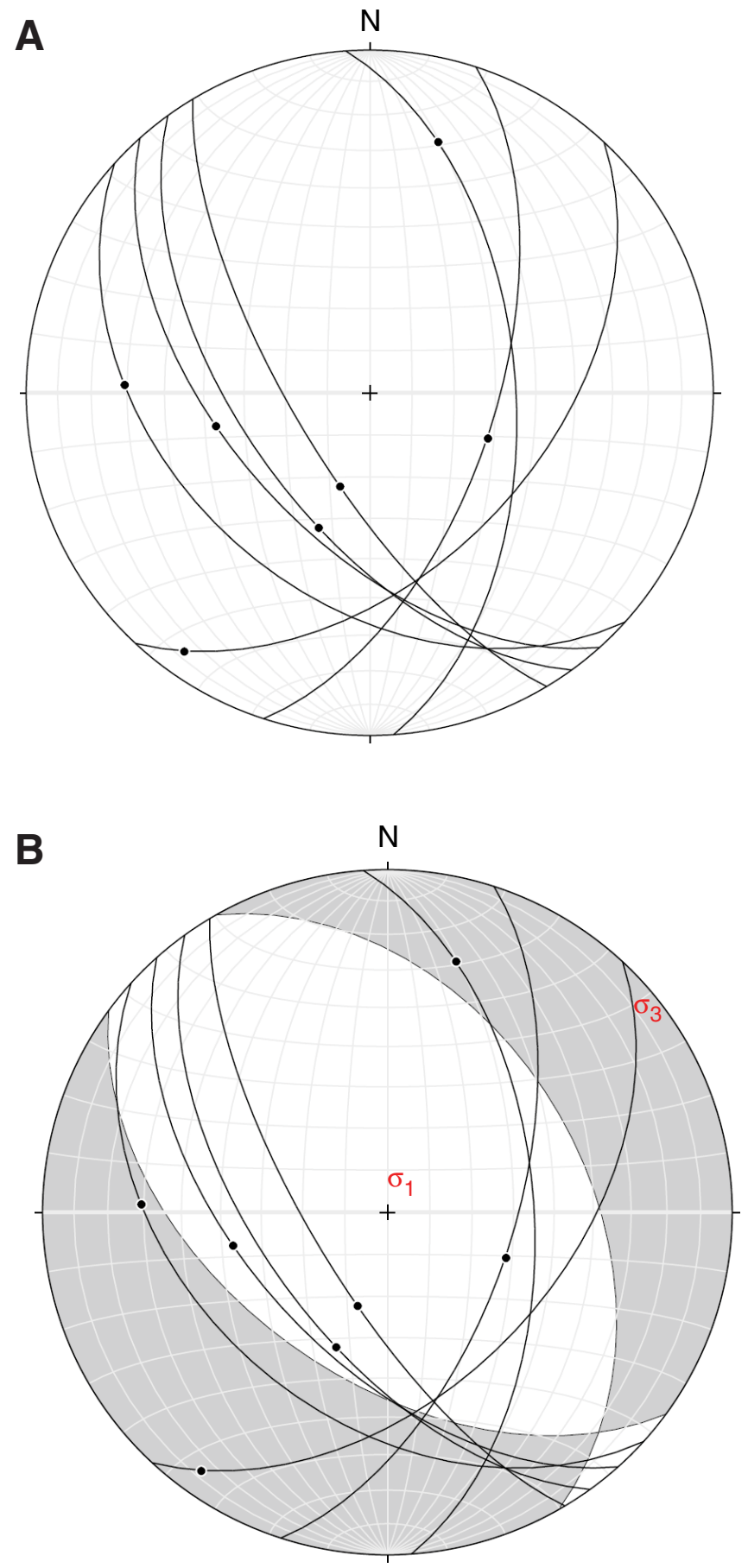
Figure F16. Photograph of a normal fault (interval 344-U1412A-7H-5A, 24-47 cm). The fault plane is marked by a dark color alteration.

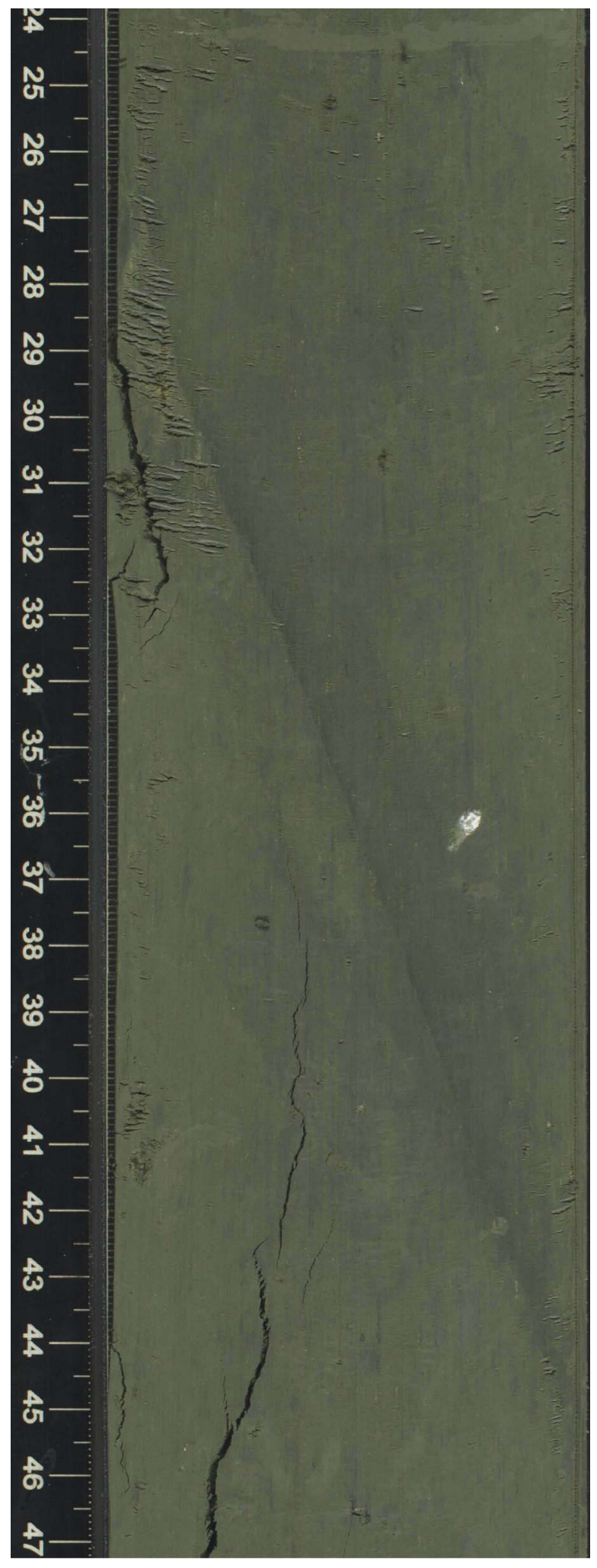


Figure F17. Profiles for salinity, chloride, potassium, and sodium, Site U1412. Dashed lines = lithostratigraphic unit boundaries. Blue arrows $=$ bottom seawater values. $\mathrm{BSR}=$ bottom-simulating reflector.
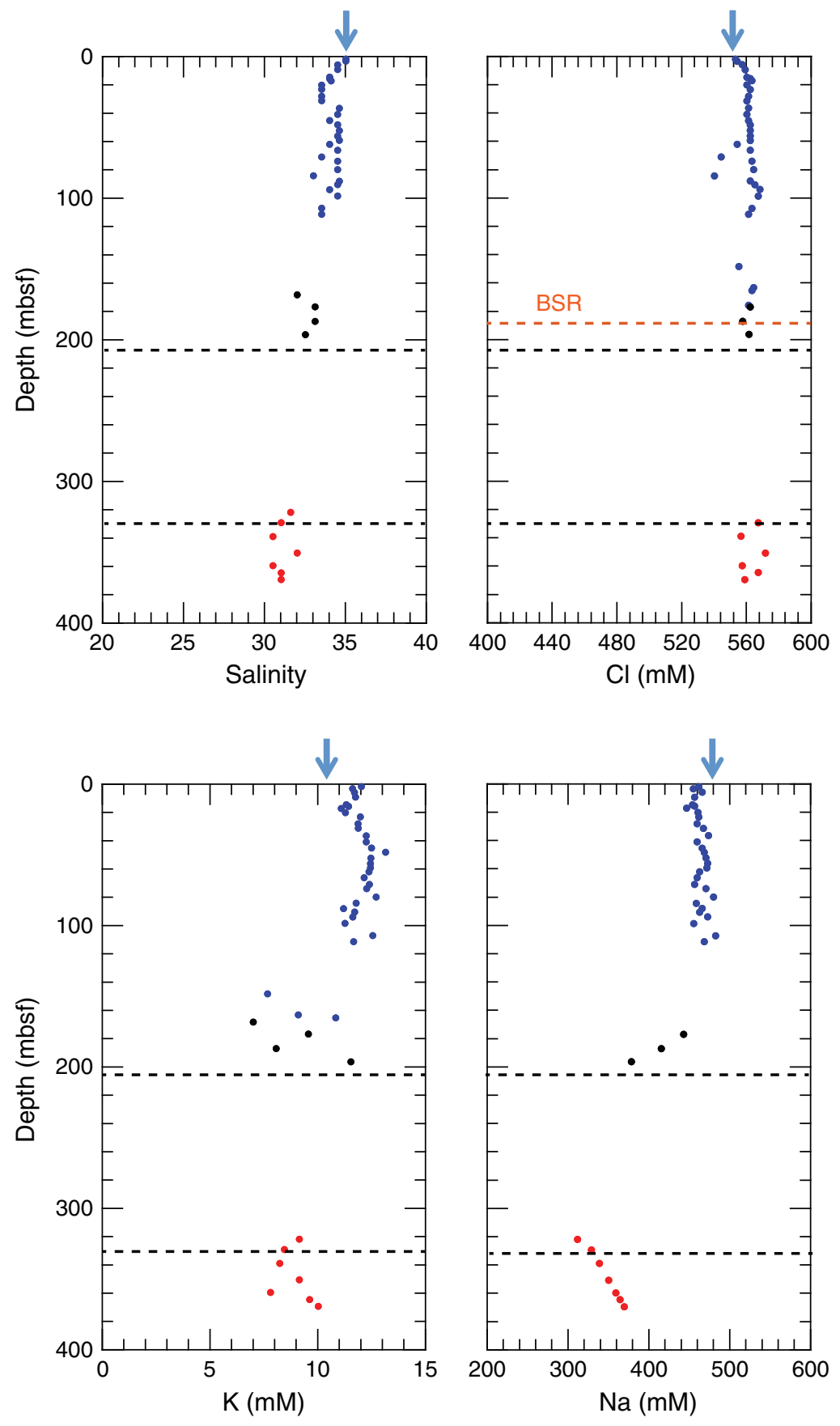

- Hole U1412A • Hole U1412B • Hole U1412C 
Figure F18. Profiles for sulfate, methane, and barium in the uppermost $30 \mathrm{~m}$ of Hole U1412A. The sulfatemethane transition zone (SMTZ) is the horizon where sulfate is consumed and methane begins to increase with depth. Barium also shows a marked increase below the SMTZ as barite dissolves in pore waters devoid of sulfate.
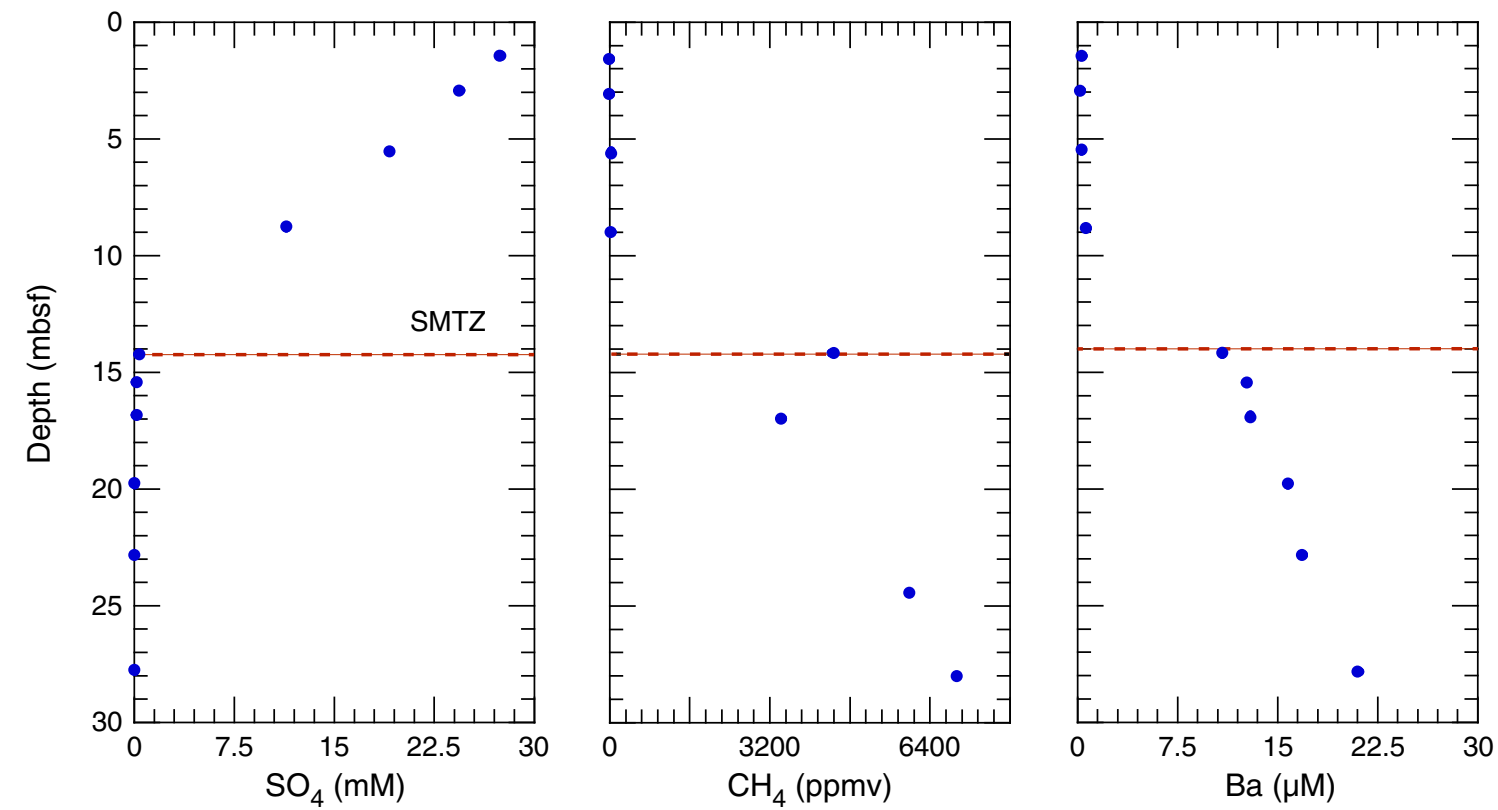
Figure F19. Profiles for alkalinity, calcium, magnesium, sulfate, ammonium, and phosphate, Site U1412. Dashed lines = lithostratigraphic unit boundaries. Blue arrows = bottom seawater values.
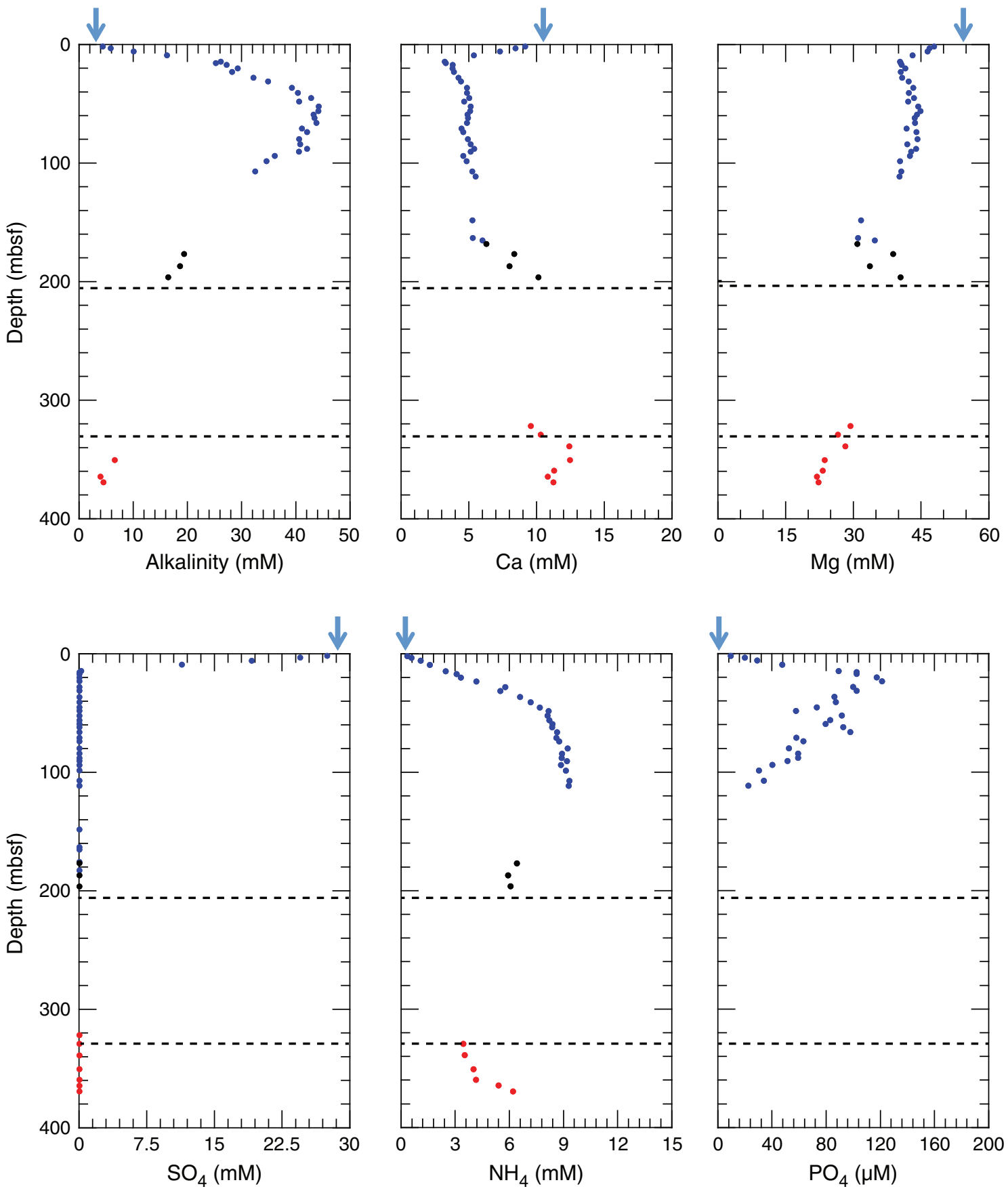

- Hole U1412A

- Hole U1412B - Hole U1412C 
Figure F20. Profiles for strontium, lithium, manganese, boron, silica, and barium, Site U1412. Dashed lines = lithostratigraphic unit boundaries. Blue arrows = bottom seawater values.
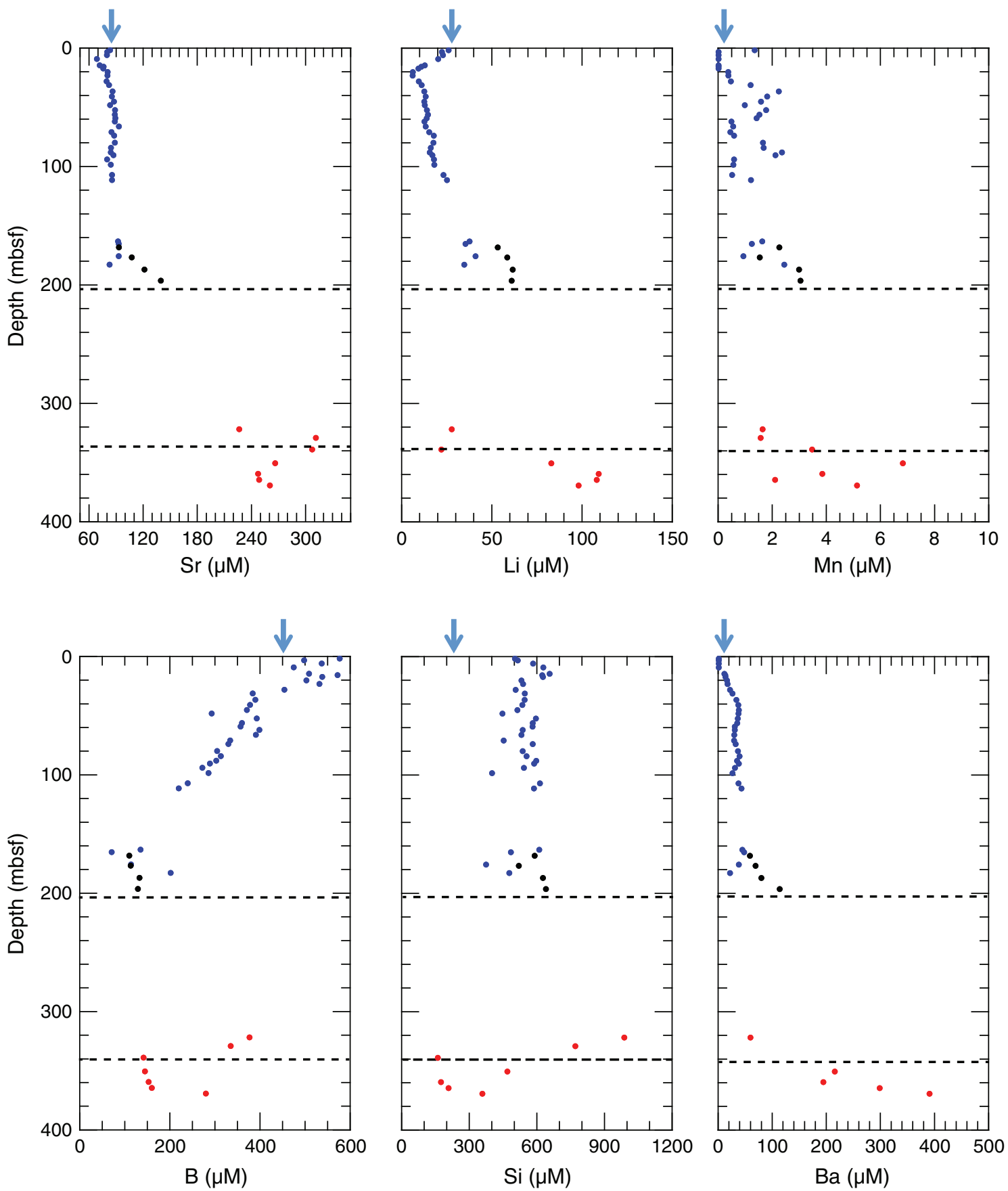

- Hole U1412A - Hole U1412B - Hole U1412C 

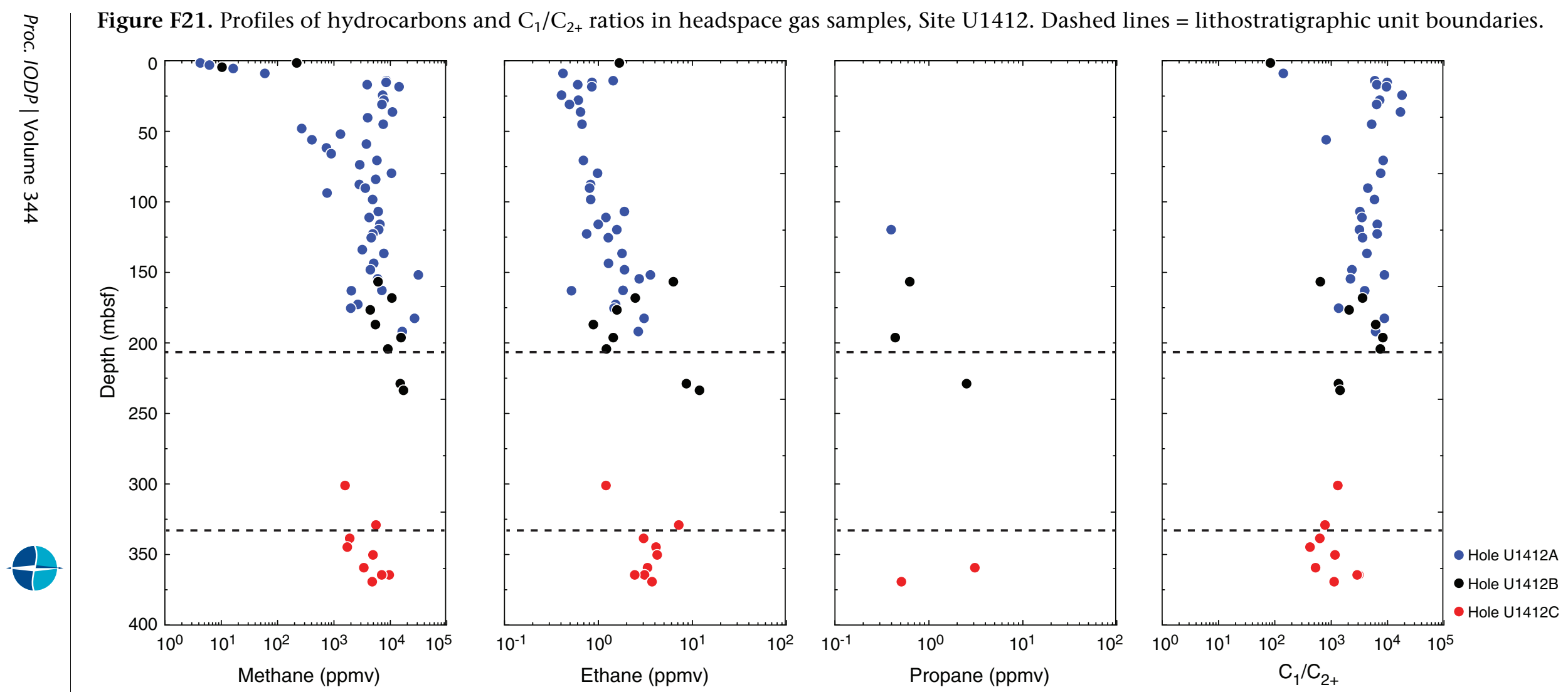

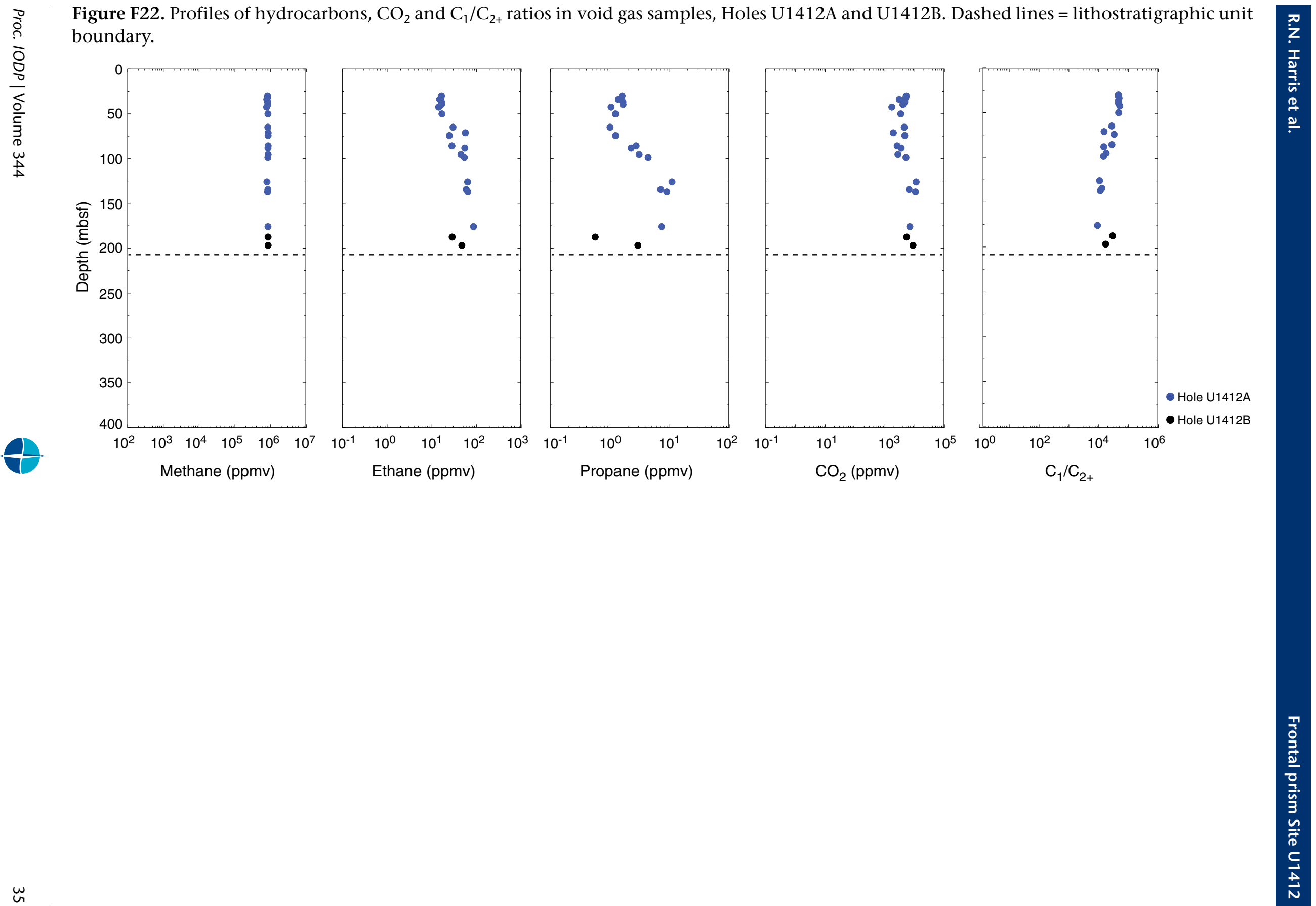
Figure F23. Downhole profiles of total carbon, inorganic carbon, total organic carbon, $\mathrm{CaCO}_{3}$, total nitrogen, and $\mathrm{C} / \mathrm{N}$ ratio, Site U1412. Dashed lines = lithostratigraphic unit boundaries.
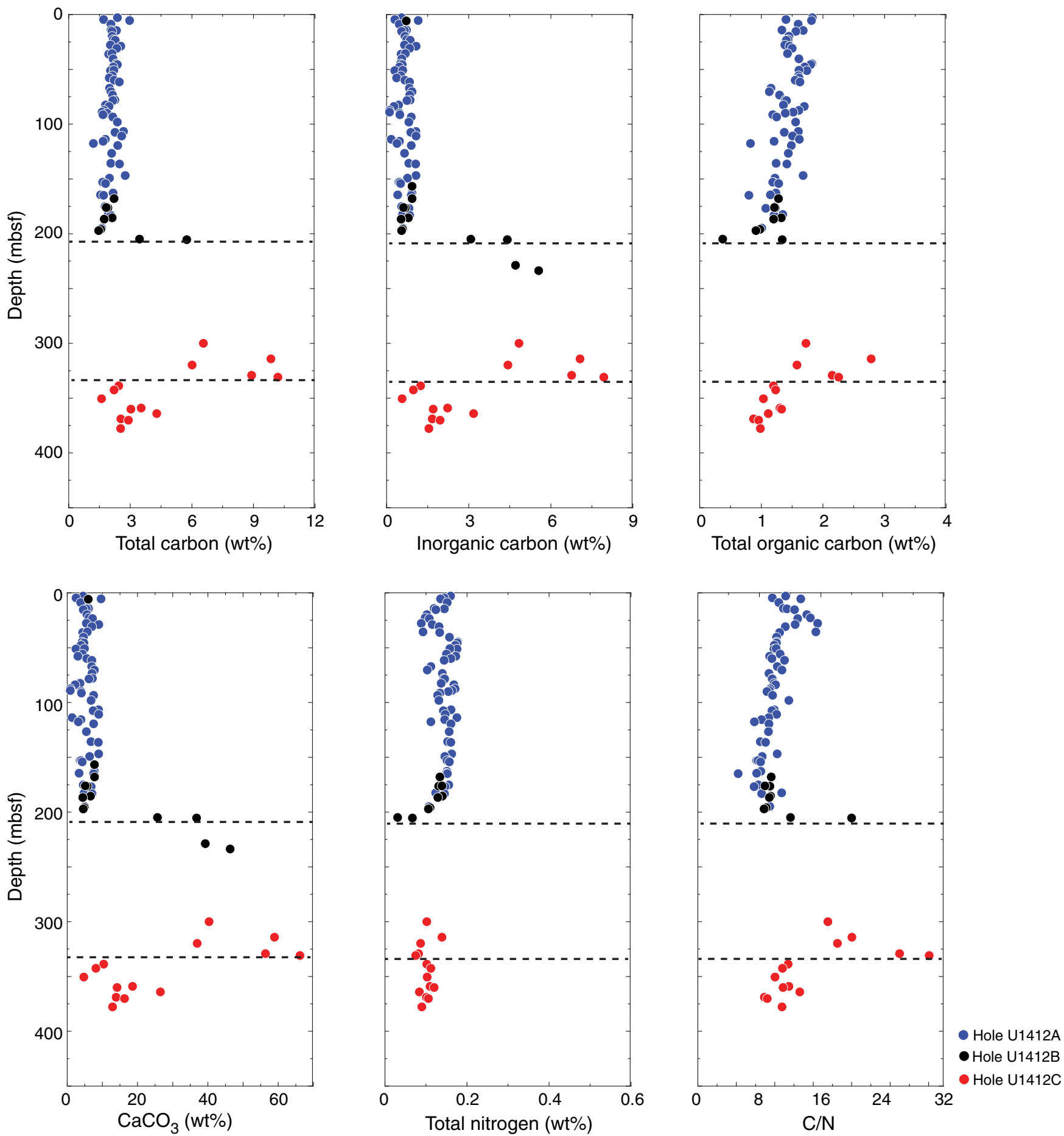
Figure F24. Gamma ray attenuation (GRA) density from the WRMSL and discrete sample porosity and wet bulk density measured using moisture and density (MAD) mass/volume Method C, Site U1412. Horizontal lines = lithostratigraphic unit boundaries.

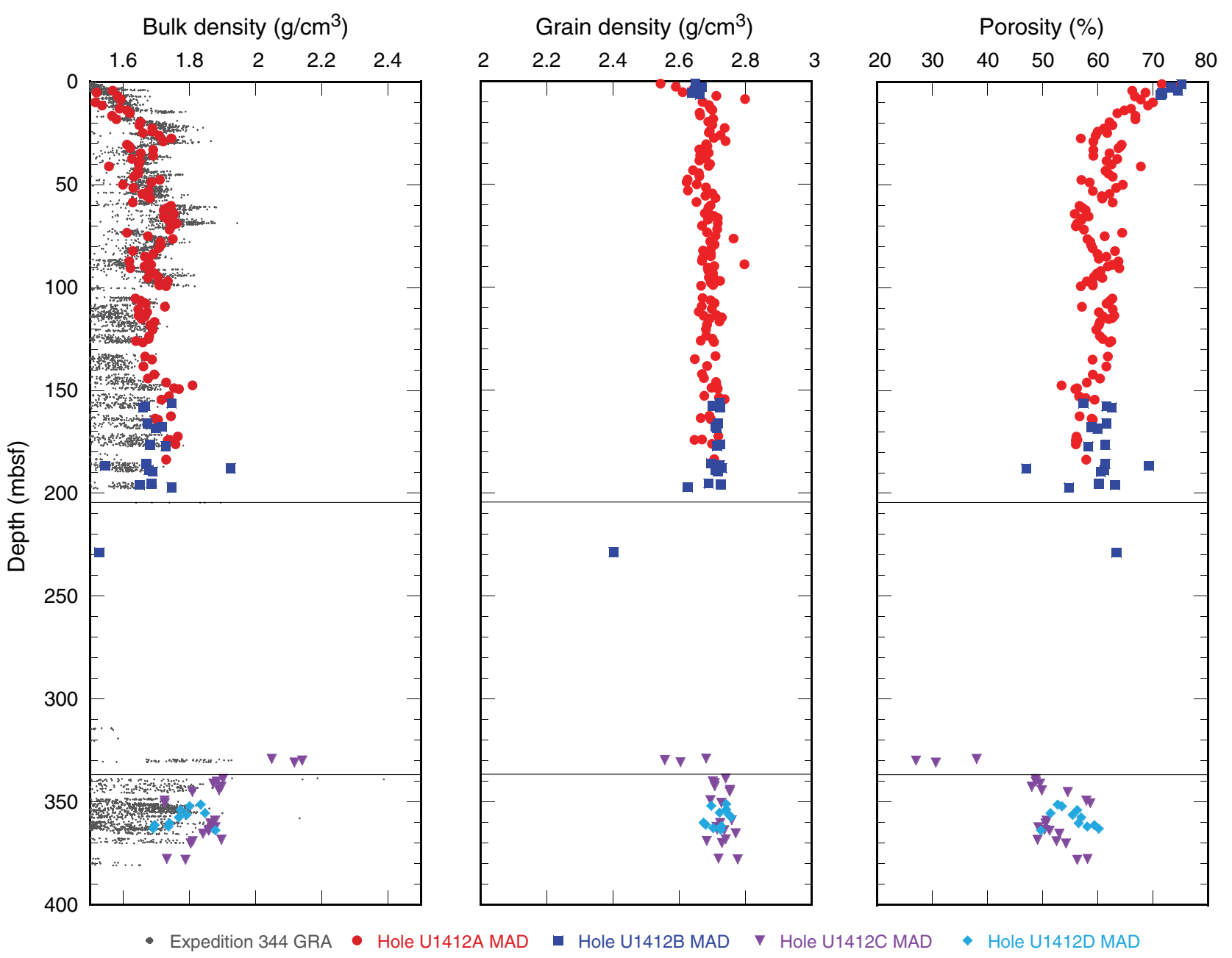


Figure F25. Magnetic susceptibility profiles, Site U1412. WRMSL $=$ Whole-Round Multisensor Logger, SHMSL = Section Half Multisensor Logger. Horizontal lines = lithostratigraphic unit boundaries.

WRMSL

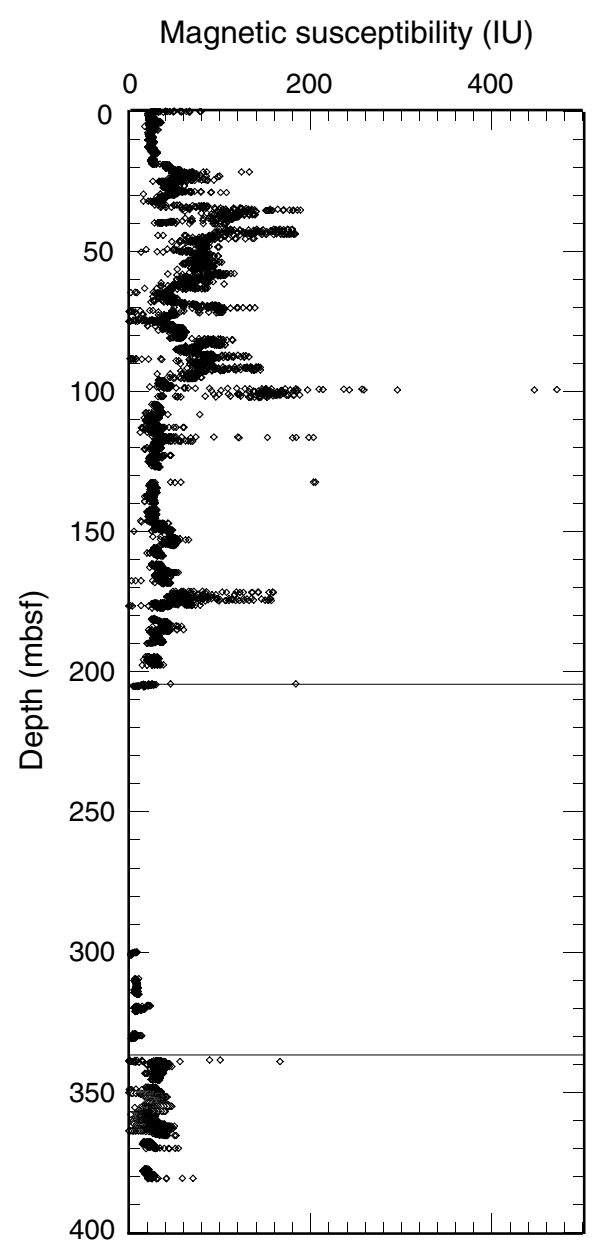

SHMSL

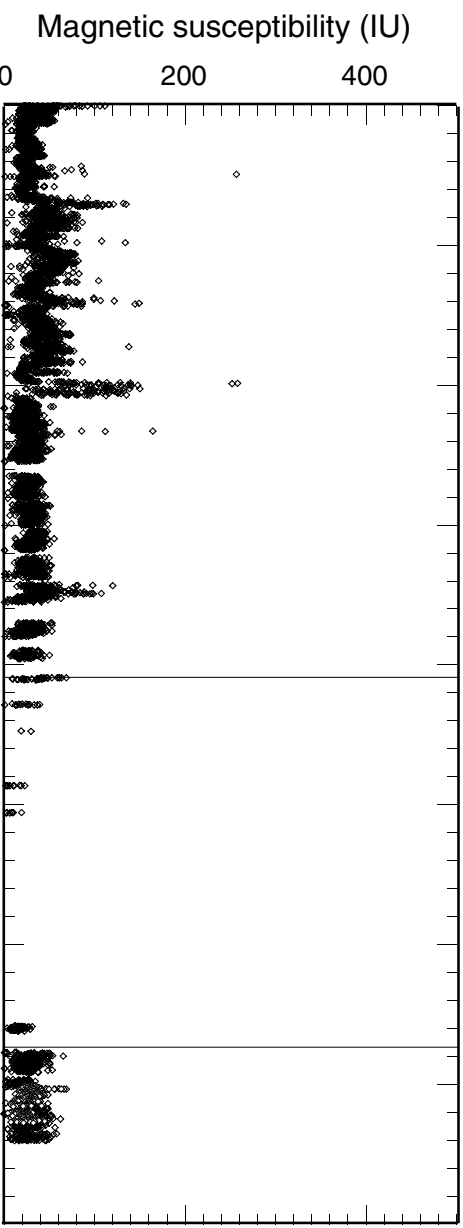


Figure F26. Downhole profile for natural gamma radiation (NGR), Site U1412. Horizontal lines = lithostratigraphic unit boundaries.

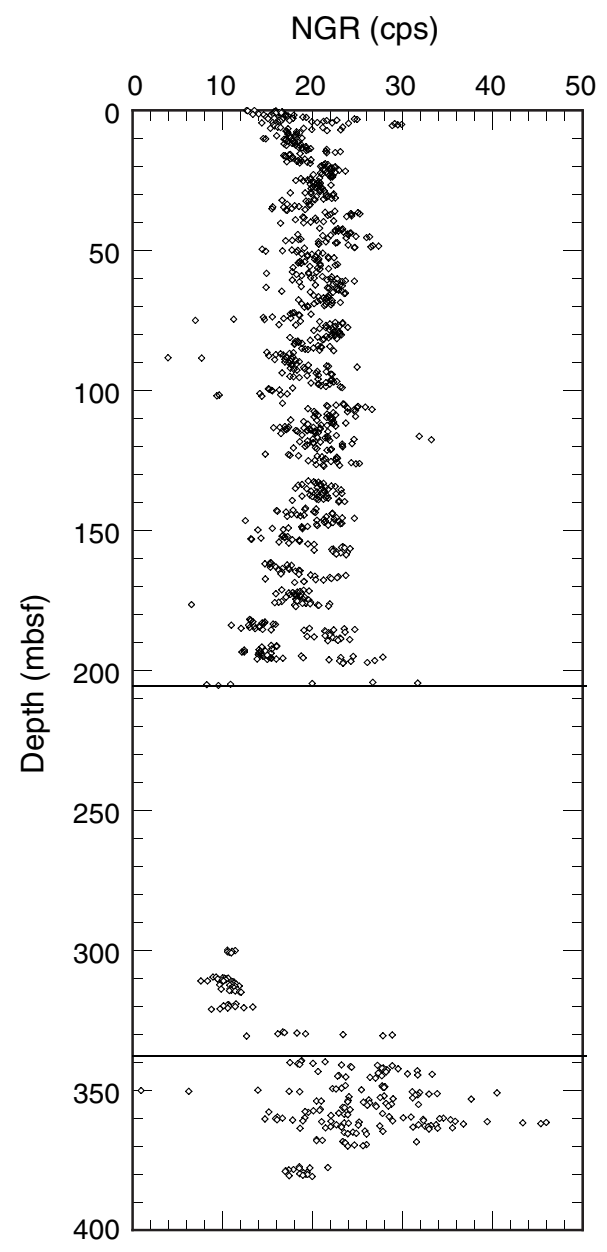


Figure F27. $P$-wave velocity measured on split cores, Site U1412. Horizontal lines = lithostratigraphic unit boundaries.

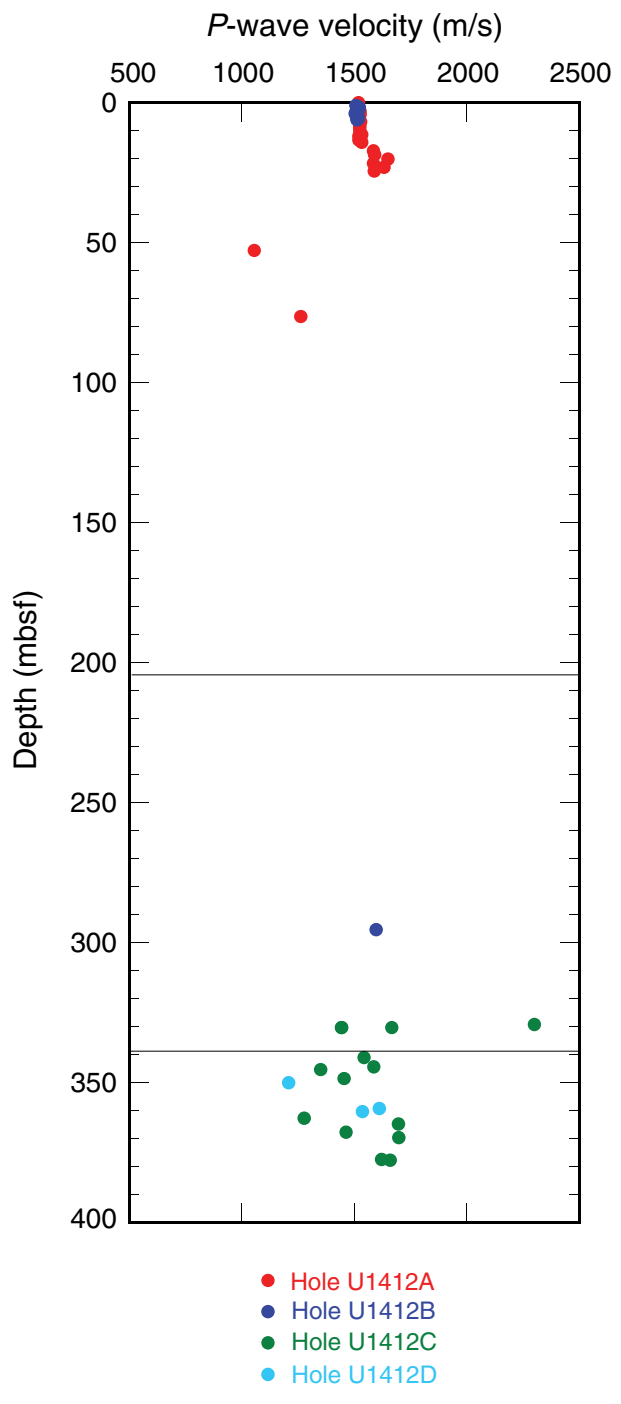


Figure F28. Thermal data, Site U1412. A. Thermal conductivity values. B. Equilibrium temperatures from Hole U1412A. Dashed line/equation = best linear fit to the temperature data. Horizontal lines = lithostratigraphic unit boundaries.

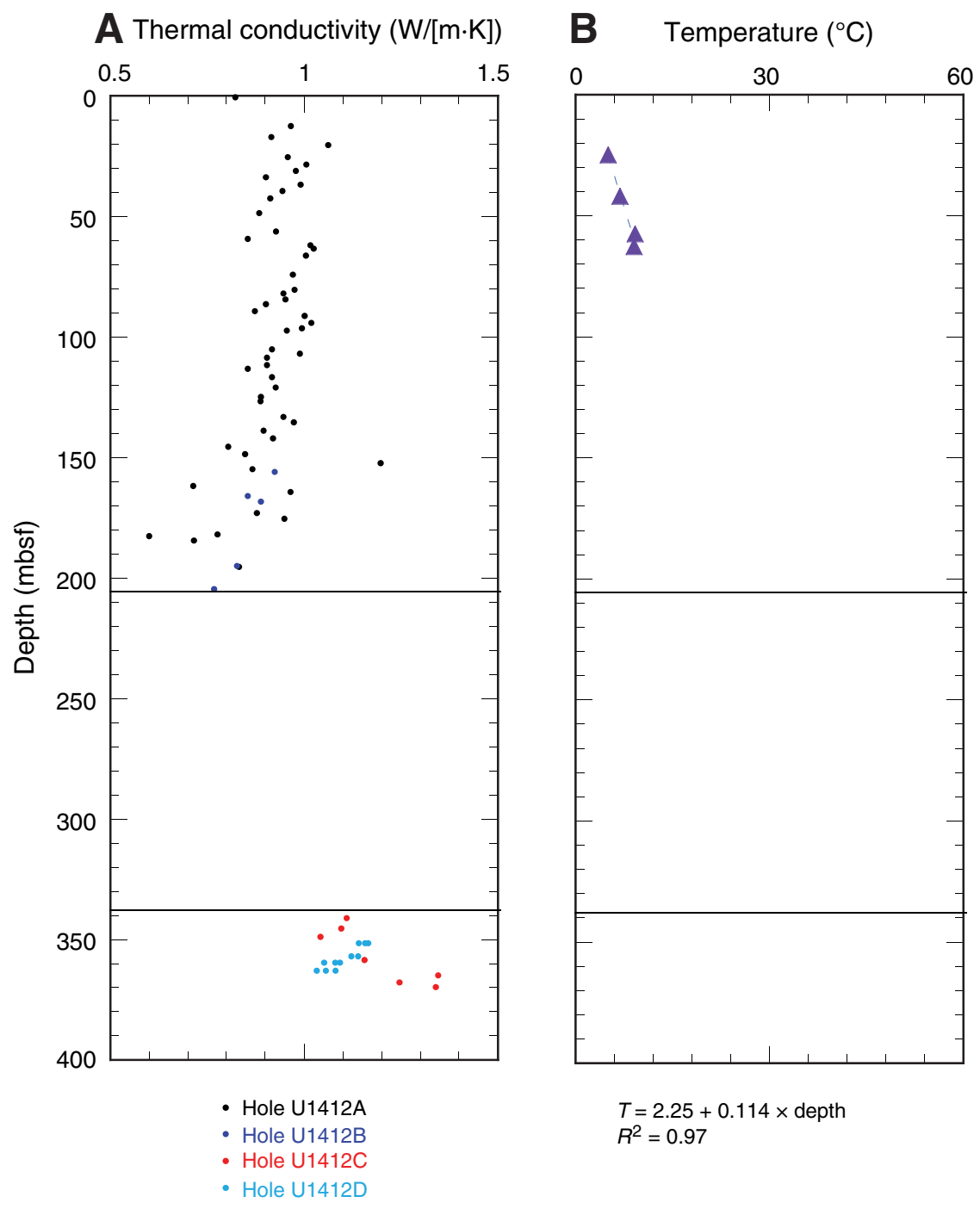


Figure F29. Strength data, Site U1412. A. Compressive strength measured using pocket (solid symbols) and needle (open symbols) penetrometers. B. Shear strength measured using an automated vane shear. Horizontal lines $=$ lithostratigraphic unit boundaries.

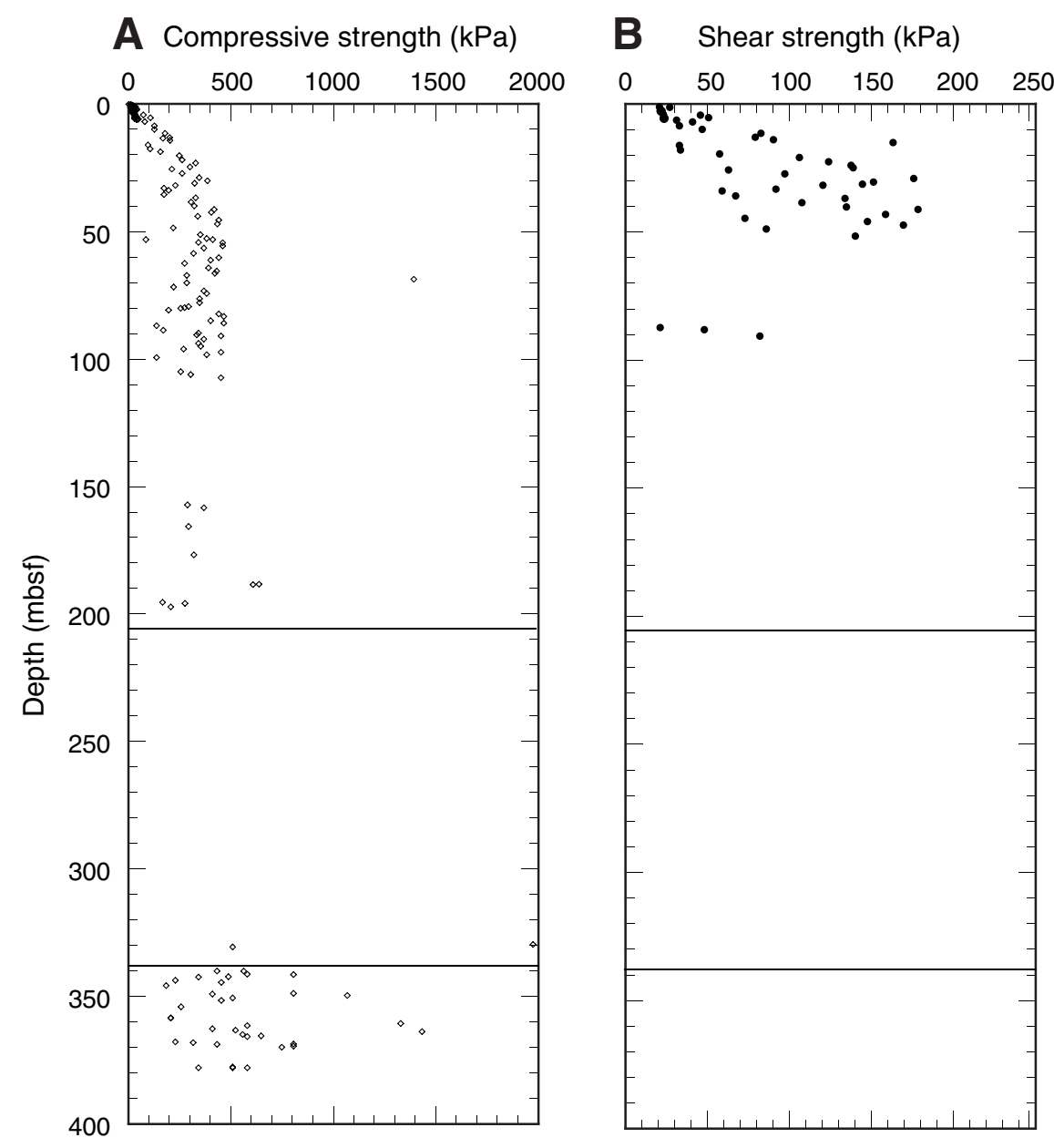


Figure F30. Formation factor calculated from electrical conductivity measurements, Site U1412.

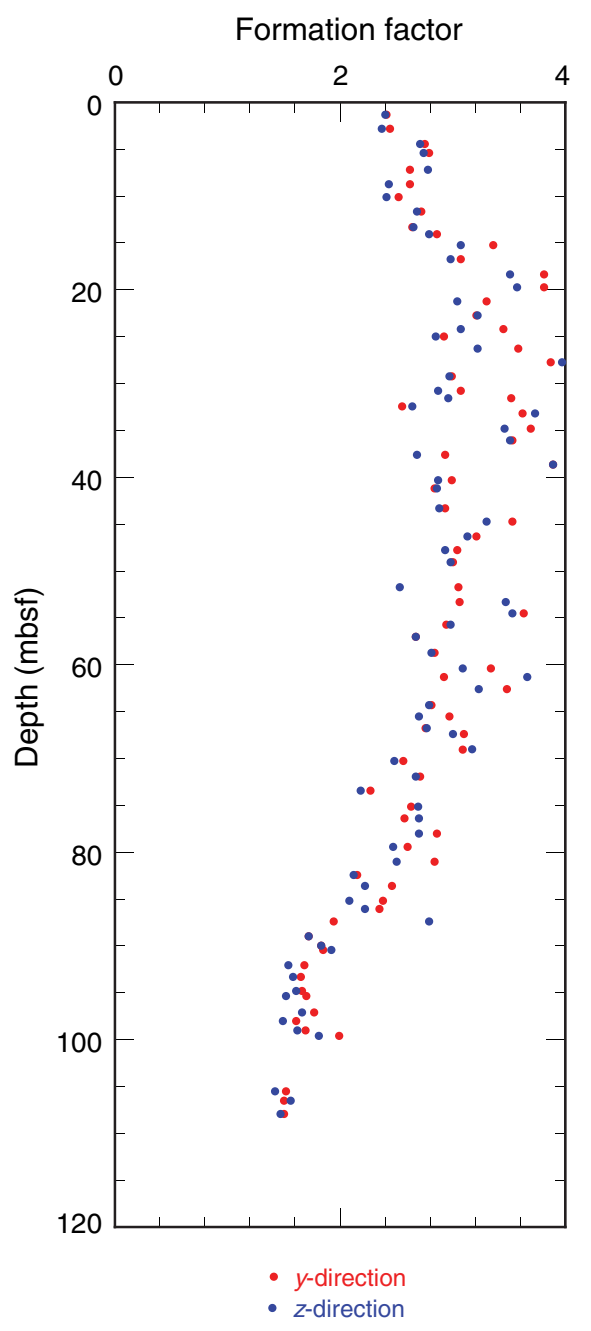


Figure F31. Reflectance $\mathrm{L}^{*}, \mathrm{a}^{*}$, and $\mathrm{b}^{*}$ profiles, Site U1412. Horizontal lines = lithostratigraphic unit boundaries.

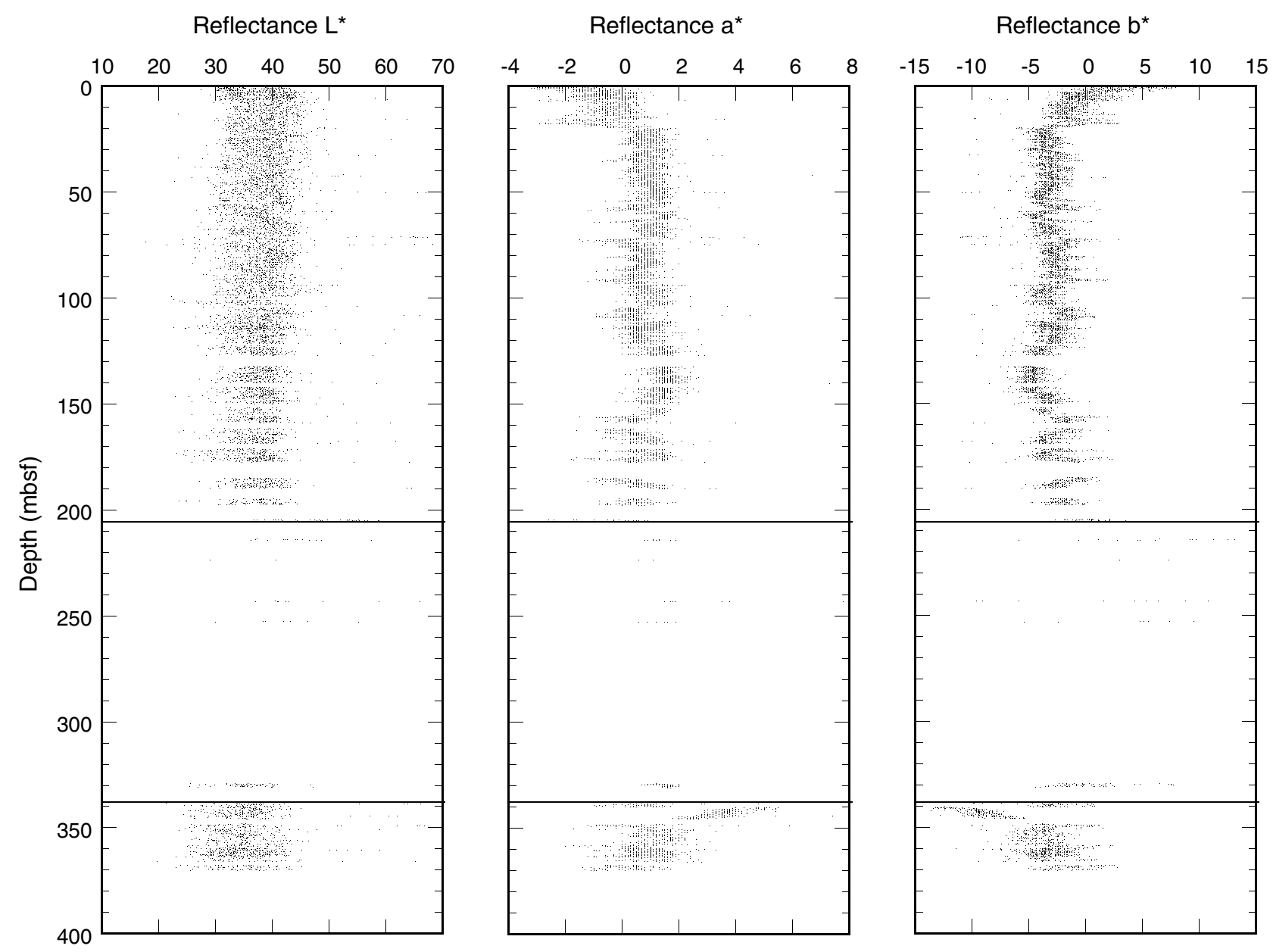


Figure F32. Paleomagnetic measurements on sediment archive-half core sections (circles) and discrete samples (crosses), Hole U1412A. A, B. NRM intensity and inclination after 0 and $40 \mathrm{mT}$ AF demagnetization. C. Characteristic remanent magnetization (ChRM) for discrete samples determined from principal component analysis.
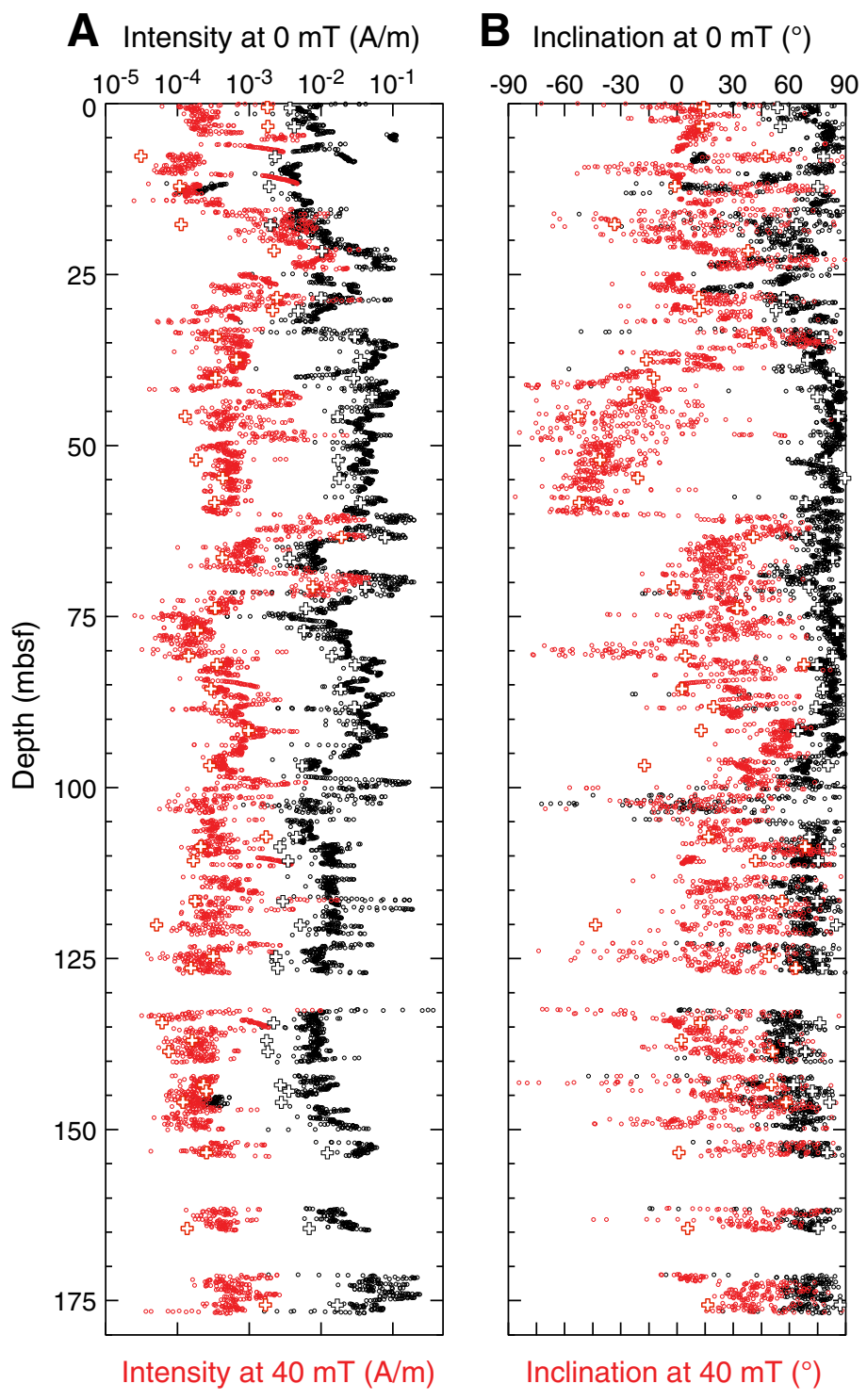

C ChRM inclination ( ${ }^{\circ}$ )

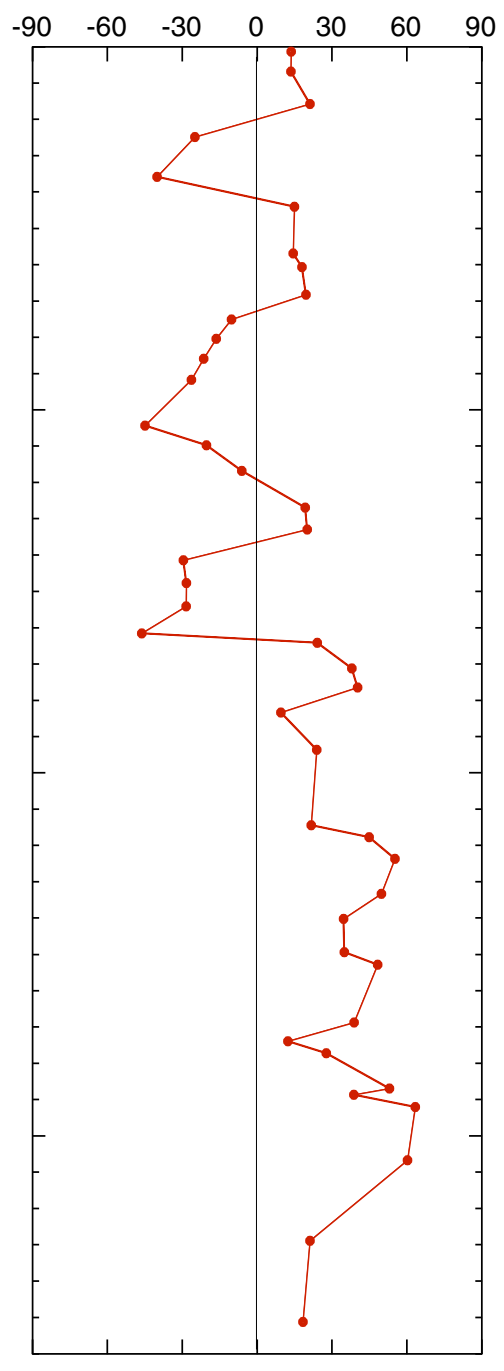


Figure F33. Paleomagnetic measurements on archive sections (open circles) and discrete samples (solid circles), Hole U1412B. A, B. NRM intensity and inclination after 0 and $40 \mathrm{mT}$ AF demagnetization. C. Characteristic remanent magnetization (ChRM) for discrete samples determined from principal component analysis.
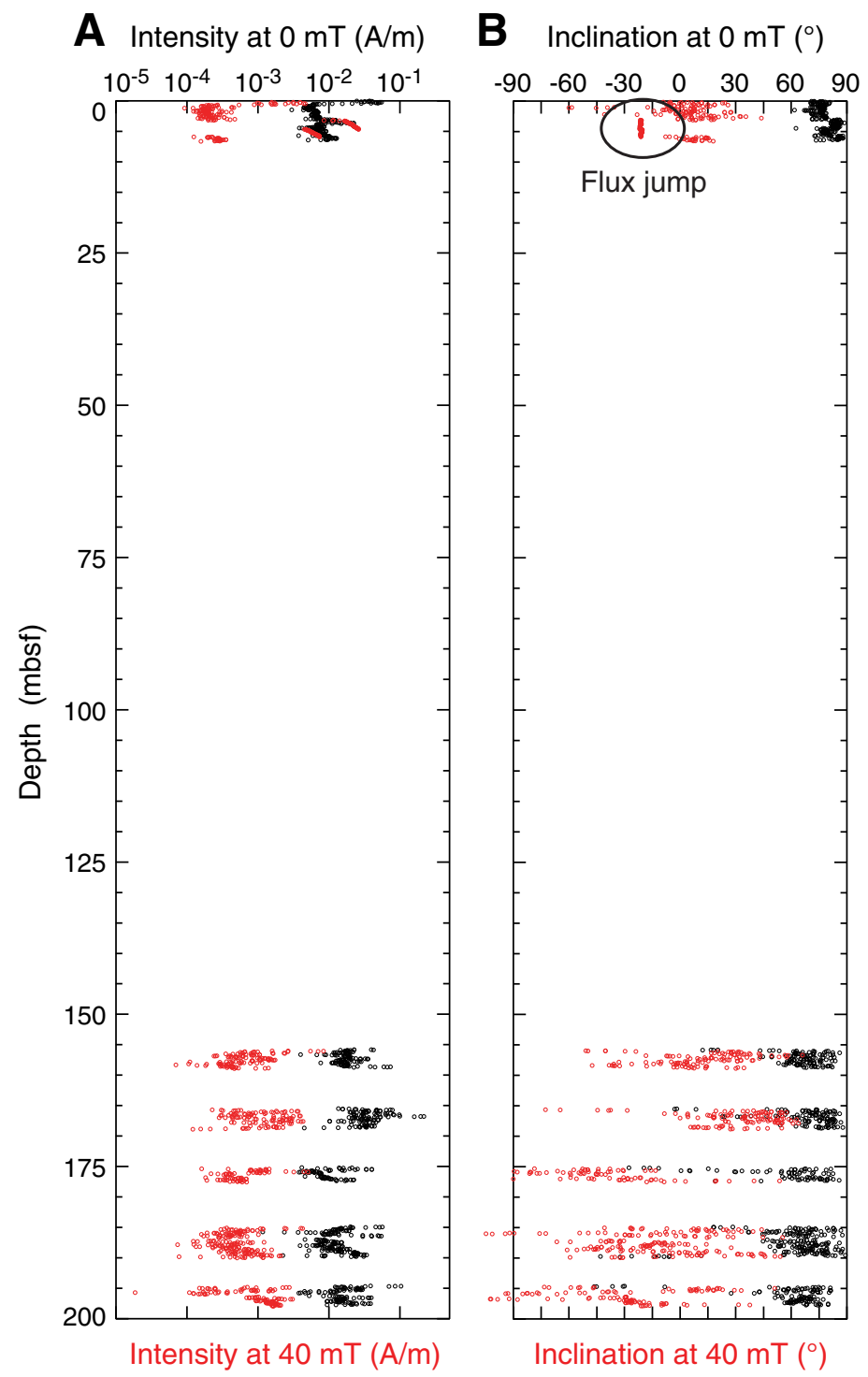

C ChRM inclination $\left(^{\circ}\right)$

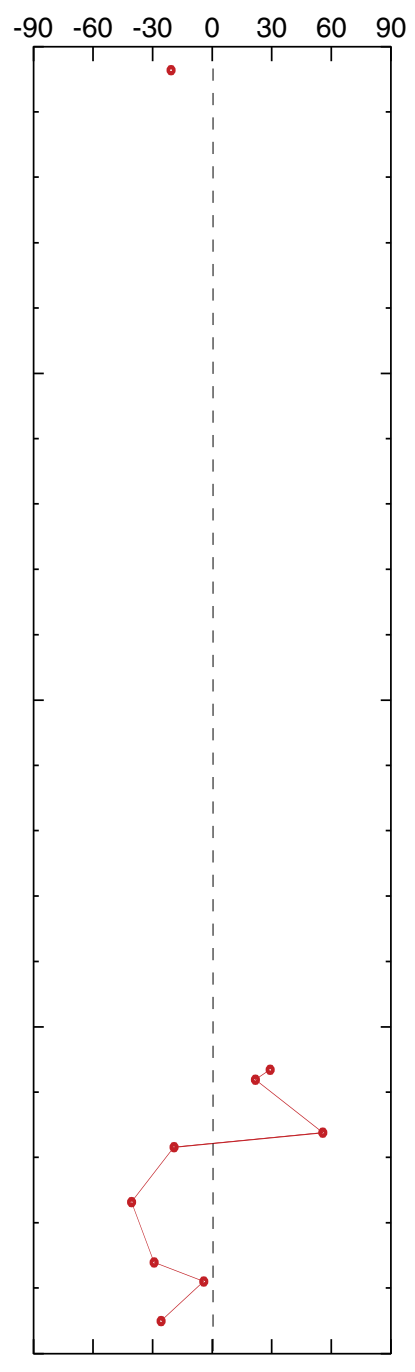


Figure F34. Paleomagnetic measurements on archive sections (open circles) and discrete samples (solid circles), Hole U1412C. A, B. NRM intensity and inclination after 0 and $40 \mathrm{mT}$ AF demagnetization. C. Characteristic remanent magnetization (ChRM) for discrete samples determined from principal component analysis.

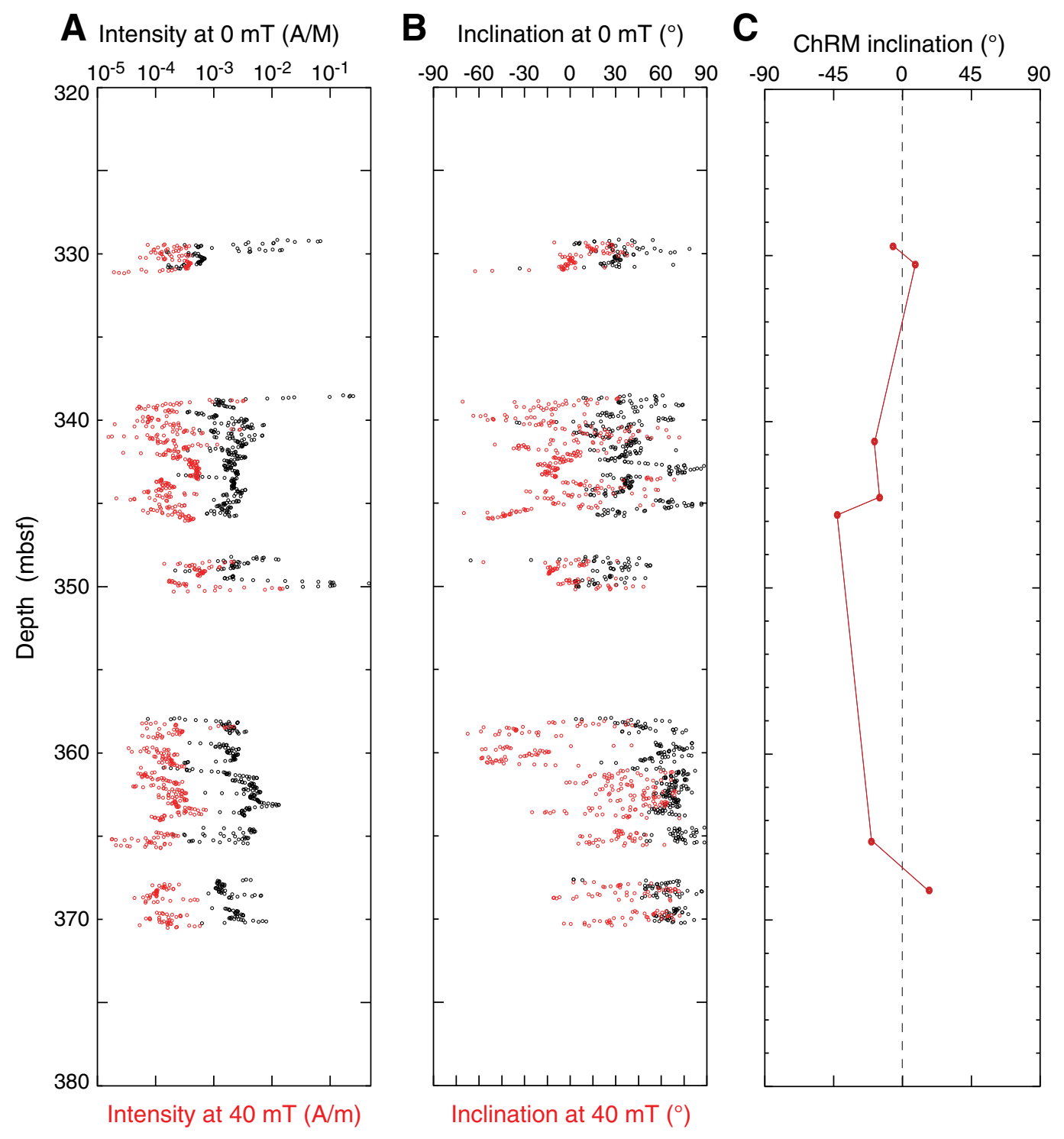


Figure F35. Paleomagnetic measurements on archive sections (open circles) and discrete samples (solid circles), Hole U1412D. A, B. NRM intensity and inclination after 0 and $40 \mathrm{mT}$ AF demagnetization. C. Characteristic remanent magnetization (ChRM) for discrete samples determined from principal component analysis.

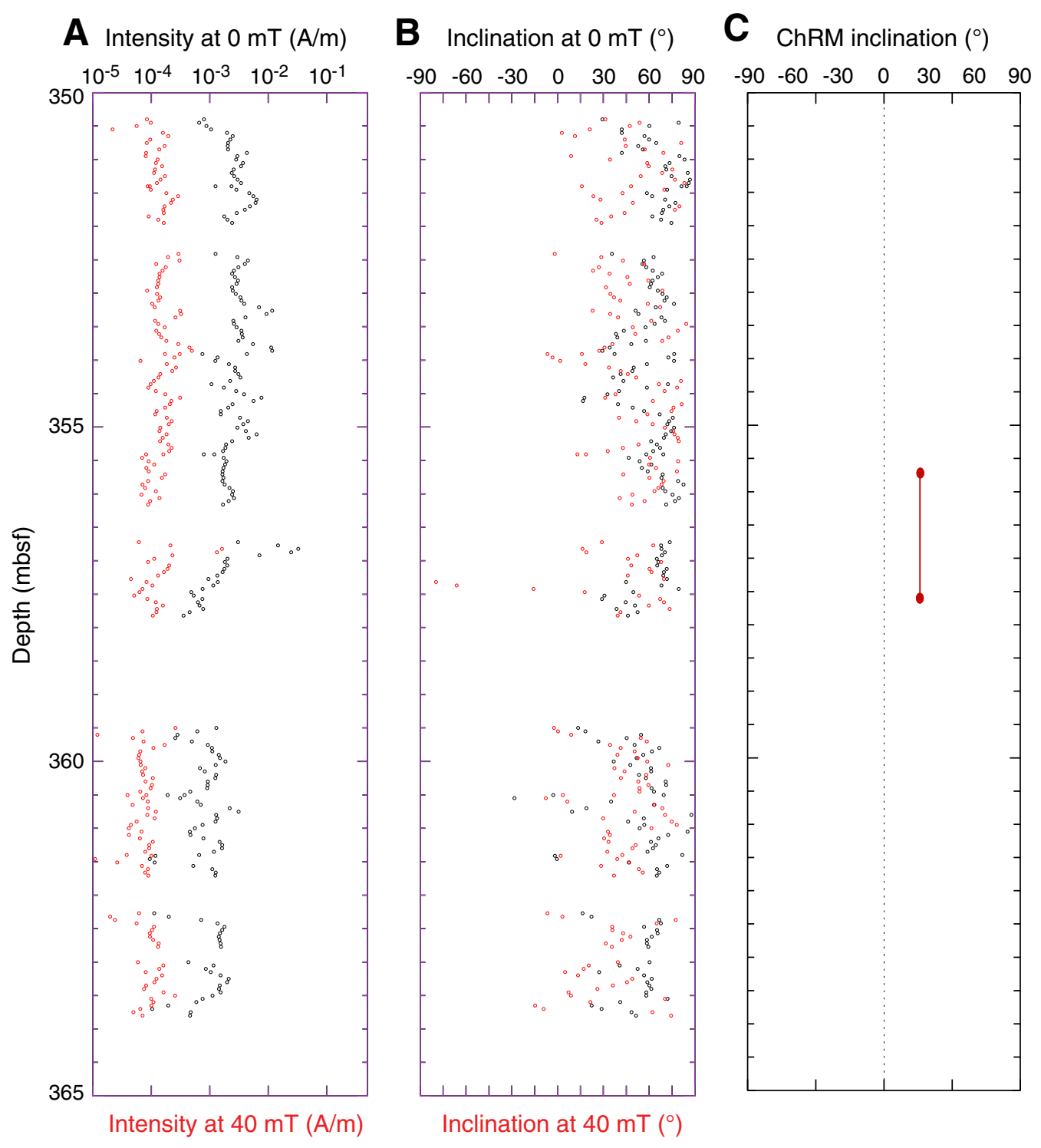


Figure F36. Representative vector end-point diagrams (Zijderveld, 1967) for sediment samples through stepwise AF demagnetization. All samples display a normal vertical component of magnetization caused by drilling that is removed after $5 \mathrm{mT}$ demagnetization. A. Pass-through section measurement (Sample 344U1412A-10H-2A, $17.5 \mathrm{~cm}$ ). B. Corresponding discrete sample (Sample 344-U1412A-10H-2W, 17.5-19.5 cm). C. Normal polarity sample (Sample 344-U1412A-12H-2W, 55-57 cm). D. Reversed polarity sample (Sample 344$\mathrm{U} 1412 \mathrm{~A}-6 \mathrm{H}-1 \mathrm{~W}, 92-94 \mathrm{~cm}$ ). Open and solid squares = projection of the magnetization vector end-points onto the vertical and horizontal planes, respectively. NRM = natural remanent magnetization.
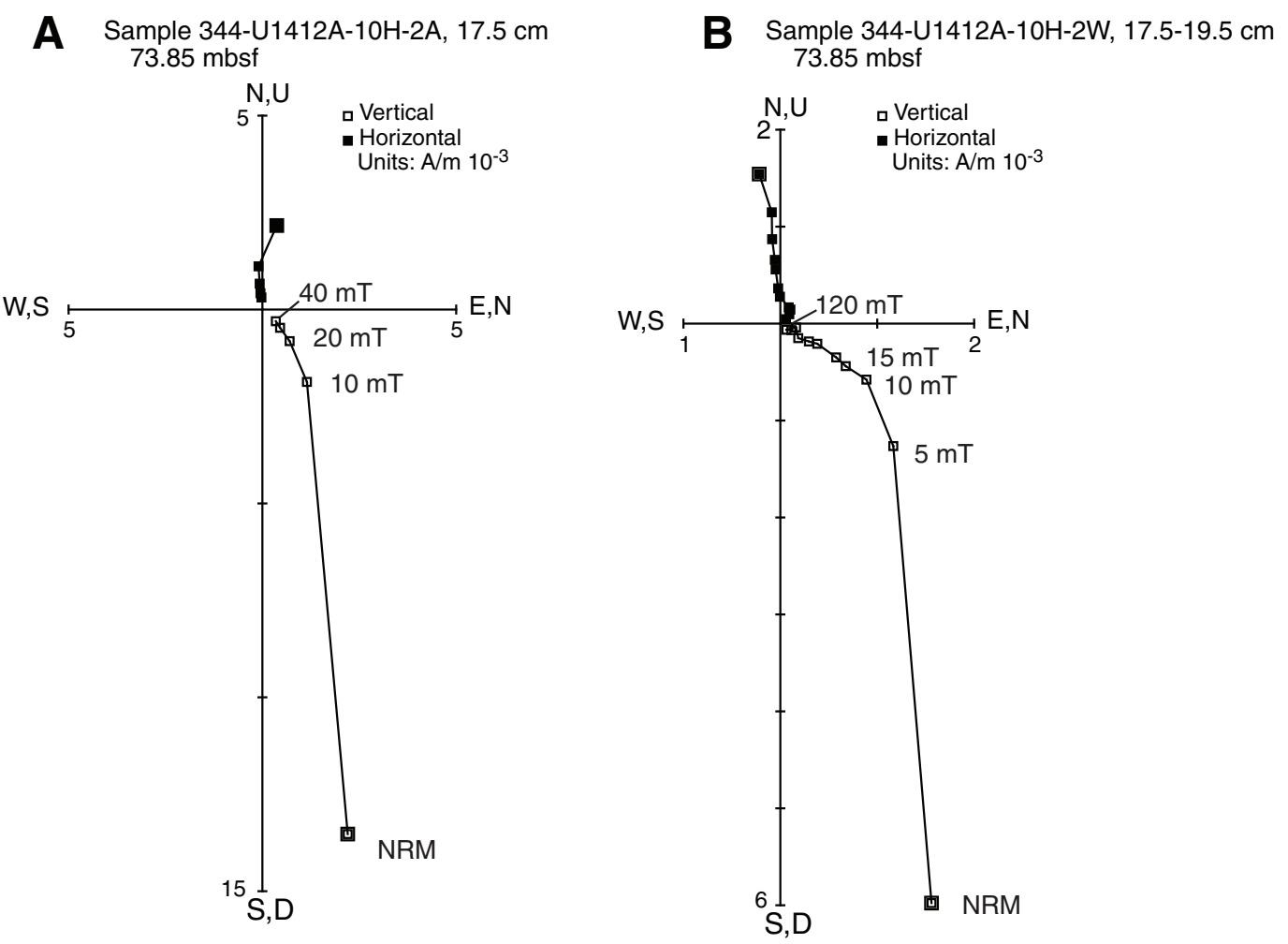
C Sample 344-U1412A-12H-2W, 55-57 cm $88.23 \mathrm{mbsf}$
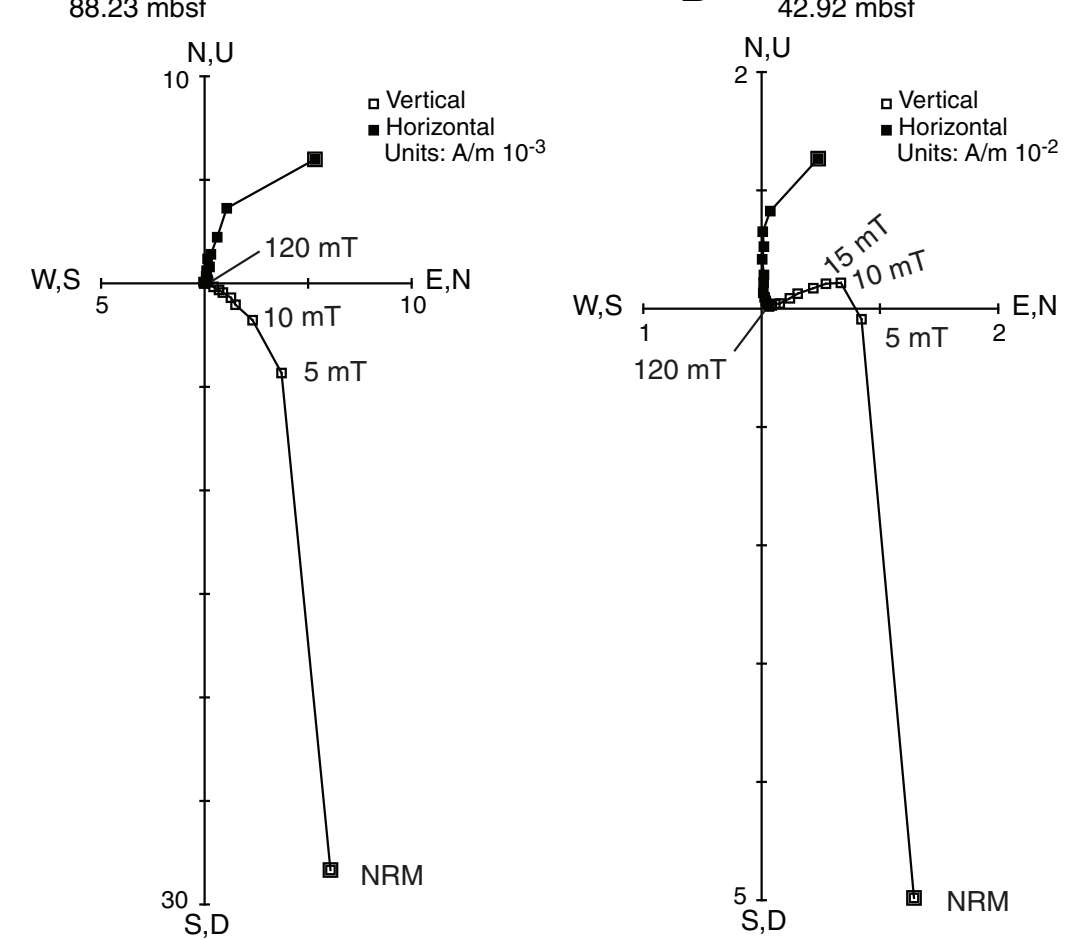
Figure F37. Correlation of Hole U1412A discrete sample magnetostratigraphy with the geomagnetic polarity timescale of Gradstein et al. (2012). Discrete sample results of characteristic remanence $(\mathrm{ChRM})$ were determined by principal component analysis (Kirschvink, 1980). Black $=$ normal polarity, white = reversed polarity.
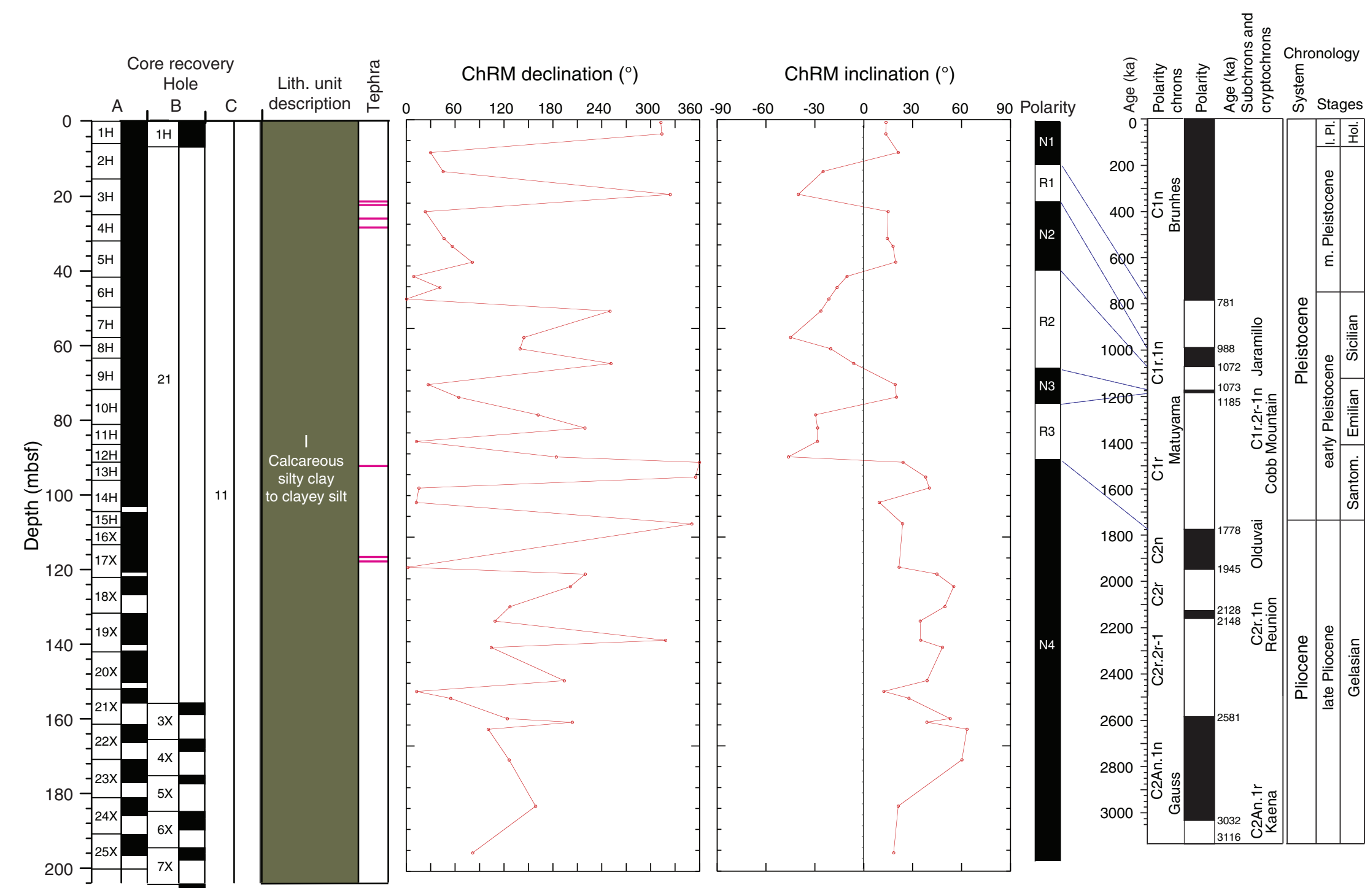
Table T1. Site U1412 coring summary. (Continued on next page.)

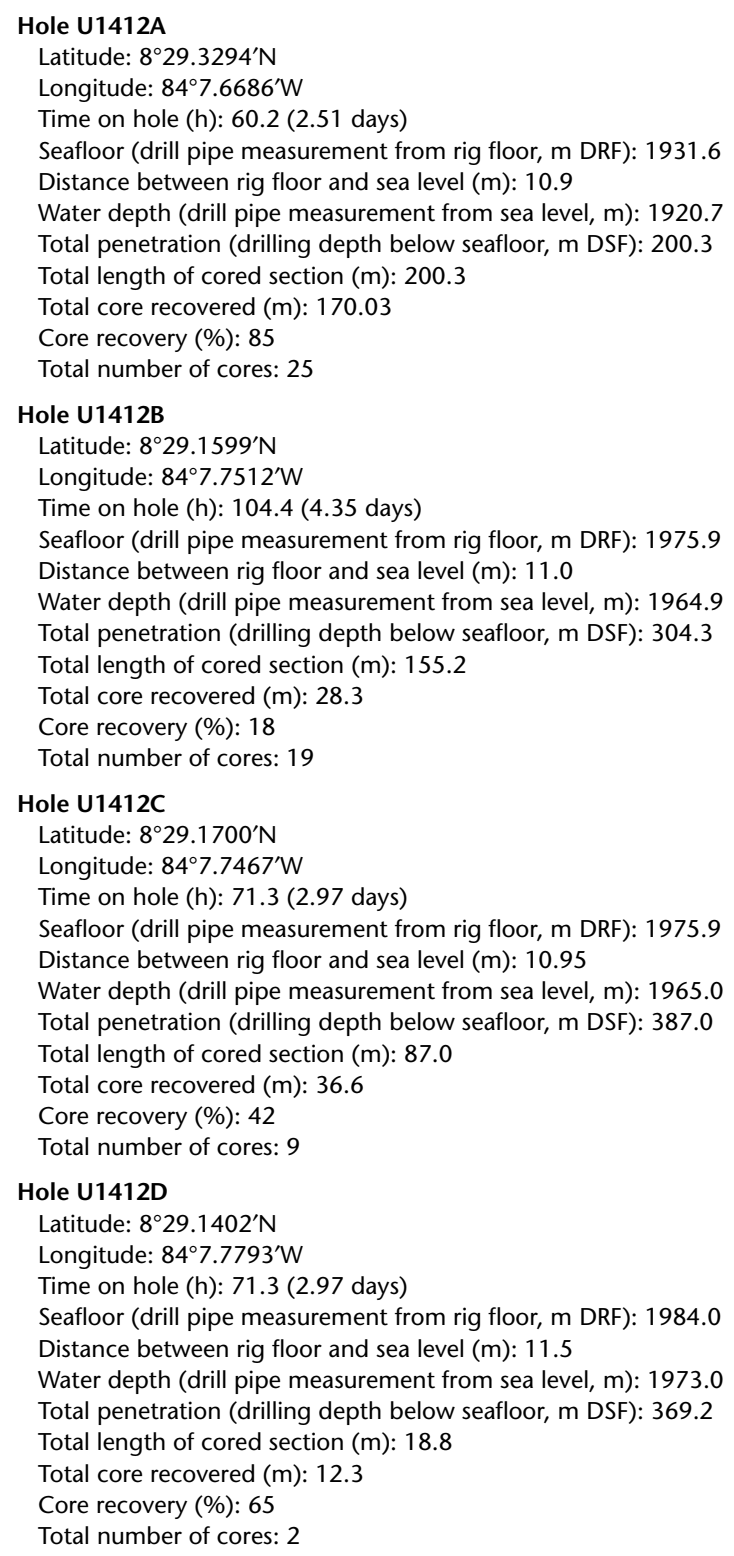

\begin{tabular}{|c|c|c|c|c|c|c|c|c|c|c|}
\hline \multirow[b]{2}{*}{ Core } & \multirow[b]{2}{*}{$\begin{array}{l}\text { Date } \\
(2012)\end{array}$} & \multirow[b]{2}{*}{$\begin{array}{l}\text { Time } \\
\text { UTC } \\
\text { (h) }\end{array}$} & \multicolumn{2}{|c|}{ Depth DSF (m) } & \multirow[b]{2}{*}{$\begin{array}{l}\text { Interval } \\
\text { advanced } \\
(\mathrm{m})\end{array}$} & \multicolumn{2}{|c|}{ Depth CSF (m) } & \multirow{2}{*}{$\begin{array}{l}\text { Length } \\
\text { of core } \\
\text { recovered } \\
(\mathrm{m})\end{array}$} & \multirow[b]{2}{*}{$\begin{array}{c}\text { Recovery } \\
\text { (\%) }\end{array}$} & \multirow[b]{2}{*}{ Comments } \\
\hline & & & $\begin{array}{l}\text { Top of } \\
\text { cored } \\
\text { interval }\end{array}$ & $\begin{array}{c}\text { Bottom of } \\
\text { cored } \\
\text { interval }\end{array}$ & & $\begin{array}{l}\text { Top of } \\
\text { cored } \\
\text { interval }\end{array}$ & $\begin{array}{c}\text { Bottom of } \\
\text { cored } \\
\text { interval }\end{array}$ & & & \\
\hline \multicolumn{11}{|c|}{ 344-U1412A- } \\
\hline $1 \mathrm{H}$ & $14 \mathrm{Nov}$ & 2135 & 0.00 & 5.90 & 5.9 & 0.00 & 5.90 & 5.90 & 100 & FlexIt \\
\hline $2 \mathrm{H}$ & $14 \mathrm{Nov}$ & 2235 & 5.90 & 15.40 & 9.5 & 5.90 & 15.76 & 9.86 & 104 & FlexIt \\
\hline $3 \mathrm{H}$ & $14 \mathrm{Nov}$ & 2355 & 15.40 & 24.90 & 9.5 & 15.40 & 25.54 & 10.14 & 107 & FlexIt, APCT-3 \\
\hline $4 \mathrm{H}$ & $15 \mathrm{Nov}$ & 0110 & 24.90 & 32.90 & 8.0 & 24.90 & 32.91 & 8.01 & 100 & FlexIt \\
\hline $5 \mathrm{H}$ & $15 \mathrm{Nov}$ & 0220 & 32.90 & 42.00 & 9.1 & 32.90 & 42.04 & 9.14 & 100 & FlexIt, APCT-3 \\
\hline $6 \mathrm{H}$ & $15 \mathrm{Nov}$ & 0330 & 42.00 & 49.50 & 7.5 & 42.00 & 49.56 & 7.56 & 101 & FlexIt \\
\hline $7 \mathrm{H}$ & $15 \mathrm{Nov}$ & 0450 & 49.50 & 57.50 & 8.0 & 49.50 & 57.58 & 8.08 & 101 & FlexIt, APCT-3 \\
\hline $8 \mathrm{H}$ & $15 \mathrm{Nov}$ & 0620 & 57.50 & 62.90 & 5.4 & 57.50 & 62.85 & 5.35 & 99 & FlexIt, APCT-3 \\
\hline $9 \mathrm{H}$ & $15 \mathrm{Nov}$ & 0730 & 62.90 & 72.20 & 9.3 & 62.90 & 72.20 & 9.34 & 100 & Flexlt \\
\hline $10 \mathrm{H}$ & $15 \mathrm{Nov}$ & 0840 & 72.20 & 81.10 & 8.9 & 72.20 & 81.10 & 8.90 & 100 & FlexIt \\
\hline $11 \mathrm{H}$ & $15 \mathrm{Nov}$ & 0945 & 81.10 & 86.30 & 5.2 & 81.10 & 86.32 & 5.22 & 100 & FlexIt \\
\hline $12 \mathrm{H}$ & $15 \mathrm{Nov}$ & 1100 & 86.30 & 90.80 & 4.5 & 86.30 & 90.84 & 4.54 & 101 & FlexIt \\
\hline $13 \mathrm{H}$ & $15 \mathrm{Nov}$ & 1230 & 90.80 & 95.90 & 5.1 & 90.80 & 95.88 & 5.08 & 100 & FlexIt \\
\hline $14 \mathrm{H}$ & $15 \mathrm{Nov}$ & 1330 & 95.90 & 104.60 & 8.7 & 95.90 & 103.90 & 8.00 & 92 & FlexIt \\
\hline $15 \mathrm{H}$ & $15 \mathrm{Nov}$ & 1445 & 104.60 & 108.20 & 3.6 & 104.60 & 108.23 & 3.63 & 101 & FlexIt \\
\hline
\end{tabular}


Table T1 (continued).

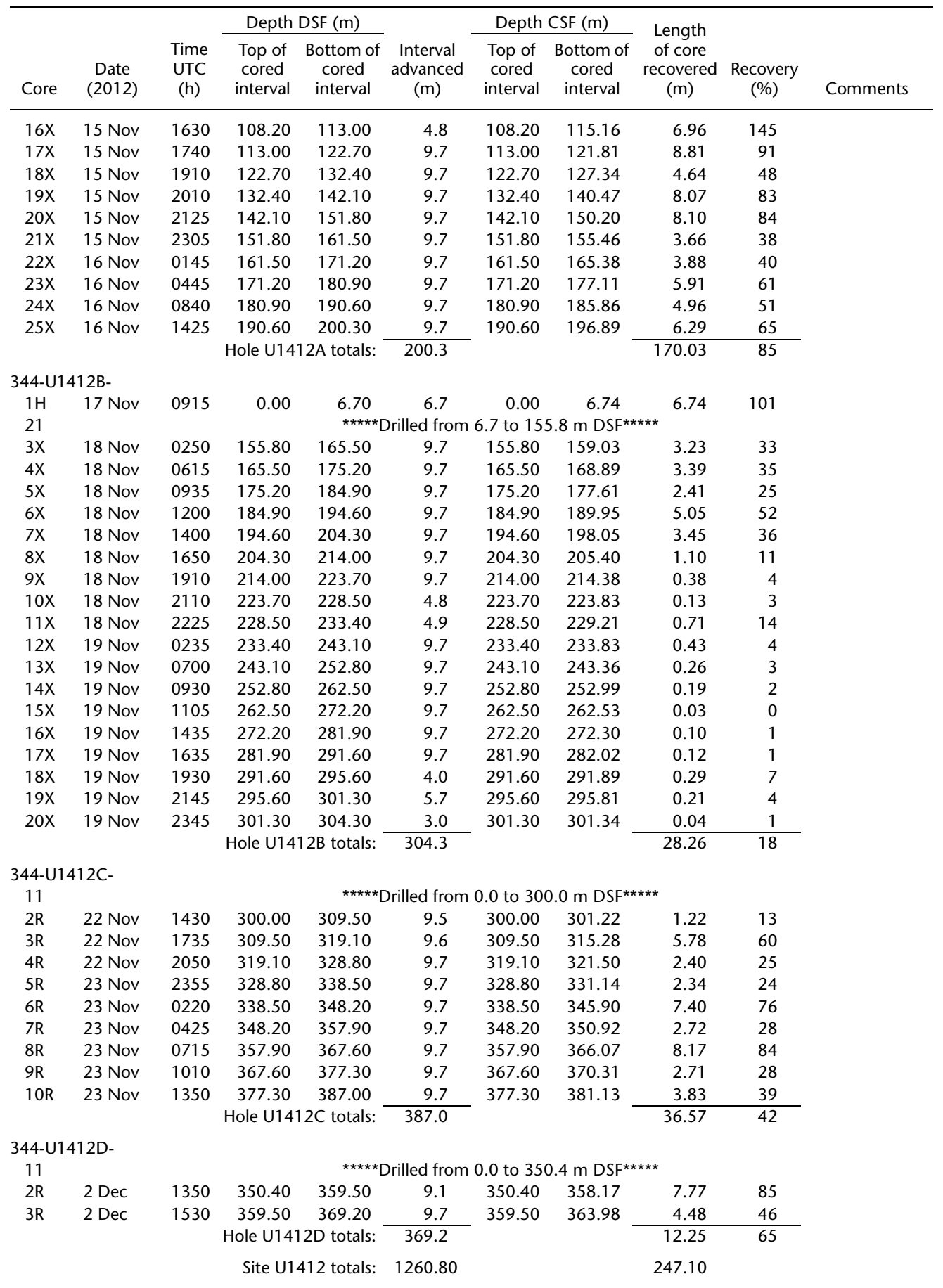

$\mathrm{DSF}=$ drilling depth below seafloor, $\mathrm{CSF}=$ core depth below seafloor. $\mathrm{H}=$ advanced piston corer core, $\mathrm{X}=$ extended core barrel core, $\mathrm{R}=$ rotary core barrel core, numeric core type $=$ drilled interval. APCT-3 = advanced piston corer temperature tool. 
Table T2. Summary of Site U1412 lithologic units.

\begin{tabular}{|c|c|c|c|c|c|c|}
\hline Unit & $\begin{array}{c}\text { Top } \\
\text { depth } \\
\text { (mbsf) }\end{array}$ & $\begin{array}{l}\text { Hole, core, section, } \\
\text { interval }(\mathrm{cm})\end{array}$ & $\begin{array}{l}\text { Bottom } \\
\text { depth } \\
\text { (mbsf) }\end{array}$ & $\begin{array}{l}\text { Hole, core, section, } \\
\text { interval }(\mathrm{cm})\end{array}$ & $\begin{array}{l}\text { Unit } \\
\text { thickness } \\
(\mathrm{m})\end{array}$ & Major lithology \\
\hline & & 344- & & $344-$ & & \\
\hline I & 0 & U1412A-2H-1, 0 & 204.74 & U1412B-8X-1, 44 & 204.74 & Calcareous silty clay to clayey silt \\
\hline II & 204.74 & U1412B-8X-1, 44 & 331.01 & U1412C-5R-CC, 10 & 126.27 & $\begin{array}{l}\text { Calcareous ooze with nannofossils } \\
\text { and biogenic silica }\end{array}$ \\
\hline \multirow[t]{2}{*}{ III } & 331.01 & U1412C-5R-CC, 10 & 387.00 & U1412C-10R-CC, 19 & 55.99 & Clayey siltstone to claystone \\
\hline & 350.40 & U1412D-2R-1, 0 & 363.98 & U1412D-3R-CC, 15 & 13.58 & \\
\hline
\end{tabular}




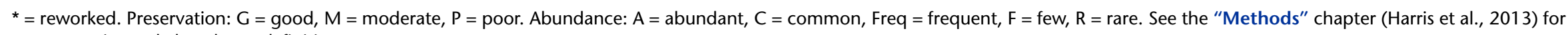
group species and abundance definitions.

Table T4. Radiolarian faunal distribution, Holes U1412A-U1412C. (This table is available in an oversized format.)

Table T5. Benthic foraminiferal faunal counts, Holes U1412A-U1412C. (This table is available in an oversized format.) 
Table T6. Uncorrected pore fluid major element concentrations, Site U1412.

\begin{tabular}{|c|c|c|c|c|c|c|c|c|c|c|c|c|c|c|c|}
\hline $\begin{array}{l}\text { Core, section, } \\
\text { interval }(\mathrm{cm})\end{array}$ & $\begin{array}{l}\text { Depth } \\
\text { (mbsf) }\end{array}$ & $\begin{array}{l}\text { Volume } \\
(\mathrm{mL})\end{array}$ & Salinity & $\mathrm{pH}$ & $\begin{array}{l}\text { Alkalinity } \\
(\mathrm{mM})\end{array}$ & $\begin{array}{l}\mathrm{SO}_{4} \mathrm{IC} \\
(\mathrm{mM})\end{array}$ & $\begin{array}{c}\mathrm{SO}_{4} \mathrm{ICP} \\
(\mathrm{mM})\end{array}$ & $\begin{array}{l}\mathrm{Cl} \mathrm{IC} \\
(\mathrm{mM})\end{array}$ & $\begin{array}{l}\mathrm{Cl} \text { titr. } \\
(\mathrm{mM})\end{array}$ & $\begin{array}{c}\mathrm{Br} \\
(\mathrm{mM})\end{array}$ & $\underset{(\mathrm{mM})}{\mathrm{Na}}$ & $\begin{array}{c}\mathrm{K} \\
(\mathrm{mM})\end{array}$ & $\begin{array}{c}\mathrm{Ca} \\
(\mathrm{mM})\end{array}$ & $\begin{array}{c}\mathrm{Mg} \\
(\mathrm{mM})\end{array}$ & $\begin{array}{l}\mathrm{NH}_{4} \\
(\mathrm{mM})\end{array}$ \\
\hline \multicolumn{16}{|l|}{ 344-U1412A- } \\
\hline $1 \mathrm{H}-1,138-150$ & 1.44 & 52.0 & 35 & 8.07 & 4.31 & 27.45 & 26.94 & 559 & 553 & 0.86 & 461 & 12.0 & 9.13 & 47.8 & 0.31 \\
\hline $1 \mathrm{H}-2,138-150$ & 2.94 & 52.0 & 35 & 7.67 & 5.78 & 24.46 & 24.38 & 551 & 554 & 0.86 & 454 & 11.6 & 8.41 & 46.8 & 0.54 \\
\hline $1 \mathrm{H}-4,98-110$ & 5.54 & 53.0 & 34.5 & 7.82 & 10.03 & 19.08 & 18.73 & 559 & 557 & 0.88 & 465 & 11.7 & 7.27 & 46.3 & 1.05 \\
\hline $2 \mathrm{H}-2,138-150$ & 8.84 & 46.0 & 34.5 & 7.97 & 16.15 & 11.35 & 16.56 & 559 & 559 & 0.90 & 456 & 11.7 & 5.34 & 43.0 & 1.56 \\
\hline $2 \mathrm{H}-6,72-84$ & 14.20 & 46.0 & 34 & 7.96 & 26.09 & 0.20 & 1.01 & 562 & 560 & 0.93 & 453 & 11.3 & 3.19 & 40.2 & 2.44 \\
\hline $2 \mathrm{H}-7,106-118$ & 15.38 & 56.0 & 34 & 7.97 & 25.13 & 0.05 & 0.38 & 559 & 562 & 0.92 & 456 & 11.4 & 3.28 & 40.4 & - \\
\hline $3 \mathrm{H}-1,138-150$ & 16.84 & 45.0 & 34 & 8.04 & 26.72 & 0.46 & 2.03 & 564 & 563 & 0.94 & 446 & 11.0 & 3.88 & 40.7 & 3.05 \\
\hline $3 \mathrm{H}-3,138-150$ & 19.84 & 25.0 & 33.5 & 7.96 & 28.99 & 0.20 & 0.57 & 561 & 560 & 0.95 & 460 & 11.2 & 3.80 & 41.5 & 3.28 \\
\hline $3 \mathrm{H}-5,138-150$ & 22.84 & 50.0 & 33.5 & 7.78 & 28.09 & 0.10 & 0.37 & 565 & 562 & 0.97 & 461 & 11.9 & 3.89 & 40.4 & 4.14 \\
\hline $4 \mathrm{H}-2,138-150$ & 27.84 & 23.0 & 33.5 & 7.9 & 31.99 & 0.10 & 0.32 & 563 & 561 & 1.01 & 459 & 11.8 & 4.23 & 40.8 & 5.74 \\
\hline $4 \mathrm{H}-4,138-150$ & 30.87 & 41.0 & 33.5 & 7.76 & 34.73 & 0.05 & 0.01 & 561 & 560 & 1.04 & 467 & 11.9 & 4.41 & 42.2 & 5.48 \\
\hline $5 \mathrm{H}-3,118-135$ & 36.19 & 46.0 & 34.5 & 7.75 & 38.61 & 0.41 & 0.45 & 563 & 561 & 1.08 & 473 & 12.2 & 4.90 & 43.2 & 6.58 \\
\hline $5 \mathrm{H}-7,133-150$ & 40.50 & 51.0 & 34.5 & 7.68 & 40.25 & 0.05 & 0.35 & 564 & 565 & 1.12 & 459 & 12.2 & 4.83 & 42.2 & 7.15 \\
\hline $6 \mathrm{H}-2,132-149$ & 44.87 & 45.0 & 34 & 7.85 & 42.6 & 0.10 & 0.24 & 563 & 561 & 1.13 & 465 & 12.5 & 5.01 & 43.4 & 7.66 \\
\hline $6 \mathrm{H}-4,134-151$ & 47.91 & 47.0 & 34.5 & 7.88 & 40.46 & 0.05 & 0.38 & 566 & 562 & 1.16 & 468 & 13.1 & 4.64 & 42.1 & 8.14 \\
\hline 7H-2, 128-145 & 51.89 & 50.0 & 34.5 & 7.72 & 43.48 & 0.41 & 0.45 & 564 & 562 & 1.17 & 470 & 12.4 & 5.16 & 44.3 & 8.09 \\
\hline 7H-5, 103-120 & 55.89 & 52.0 & 34.5 & 7 & 43.99 & 0.05 & 0.16 & 565 & 562 & 1.19 & 472 & 12.4 & 5.08 & 44.8 & 8.19 \\
\hline $8 \mathrm{H}-1,129-151$ & 58.90 & 53.0 & 34.5 & 7.8 & 41.83 & 0.87 & 1.09 & 562 & 562 & 1.18 & 471 & 12.3 & 5.01 & 44.1 & 8.37 \\
\hline $8 \mathrm{H}-3,100-122$ & 61.62 & 44.0 & 34 & 7.66 & 43.37 & 0.00 & 0.31 & 556 & 554 & 1.20 & 462 & 12.4 & 4.91 & 43.5 & 8.35 \\
\hline $9 \mathrm{H}-2,128-150$ & 65.76 & 34.0 & 34.5 & 7.77 & 43.65 & 0.05 & 0.27 & 566 & 562 & 1.24 & 459 & 12.1 & 4.83 & 43.6 & 8.62 \\
\hline $9 \mathrm{H}-6,135-157$ & 70.54 & 52.0 & 33.5 & 7.94 & 40.98 & 0.05 & 0.35 & 548 & 544 & 1.22 & 456 & 12.4 & 4.44 & 41.7 & 8.57 \\
\hline $10 \mathrm{H}-1,128-150$ & 73.59 & 56.0 & 34.5 & 7.81 & 41.62 & 0.26 & 0.36 & 565 & 565 & 1.27 & 470 & 12.2 & 4.60 & 43.9 & 8.73 \\
\hline $10 \mathrm{H}-5,134-156$ & 79.59 & 51.0 & 34.5 & 7.86 & 40.52 & 0.00 & 0.31 & 566 & 564 & 1.28 & 479 & 12.7 & 4.90 & 44.1 & 9.19 \\
\hline $11 \mathrm{H}-2,130-152$ & 83.93 & 43.0 & 33 & 7.86 & 40.59 & 0.10 & 0.26 & 546 & 540 & 1.26 & 458 & 11.8 & 5.11 & 41.9 & 8.88 \\
\hline $12 \mathrm{H}-1,115-137$ & 87.56 & 40.0 & 34.5 & 7.79 & 41.14 & 0.56 & 0.79 & 563 & 562 & 1.30 & 465 & 11.1 & 5.45 & 43.8 & 8.87 \\
\hline $12 \mathrm{H}-3,94-116$ & 90.13 & 57.0 & 34.5 & 7.84 & 40.04 & 0.31 & 0.51 & 567 & 565 & 1.31 & 462 & 11.7 & 5.15 & 42.7 & 9.16 \\
\hline $13 \mathrm{H}-2,124-146$ & 93.62 & 51.0 & 34 & 7.7 & 35.8 & 0.20 & 0.45 & 566 & 568 & 1.32 & 472 & 11.6 & 4.59 & 42.5 & 8.83 \\
\hline $14 \mathrm{H}-2,80-102$ & 98.22 & 52.0 & 34.5 & 7.78 & 34.34 & 0.15 & 0.16 & 567 & 567 & 1.33 & 455 & 11.2 & 4.83 & 40.3 & 9.12 \\
\hline $15 \mathrm{H}-2,93-115$ & 106.75 & 51.0 & 33.5 & 7.76 & 32.31 & 0.10 & 0.33 & 571 & 563 & 1.36 & 482 & 12.5 & 5.25 & 40.6 & 9.30 \\
\hline $16 \mathrm{X}-2,126-148$ & 110.98 & 12.0 & 33.5 & - & - & 0.20 & 0.41 & 563 & 561 & 1.35 & 468 & 11.6 & 5.51 & 40.2 & 9.26 \\
\hline $20 X-4,131-151$ & 148.01 & 0.8 & - & - & - & 0.05 & - & 559 & 555 & 1.38 & 362 & 7.65 & 5.25 & 31.6 & - \\
\hline $22 X-1,131-151$ & 162.91 & 2.3 & - & - & - & 2.40 & - & 563 & 564 & 1.32 & 376 & 9.04 & 5.62 & 32.4 & - \\
\hline $22 X-3,68-88$ & 165.01 & 1.8 & - & - & - & 0.82 & - & 569 & 563 & 1.39 & 442 & 10.8 & 6.08 & 35.0 & - \\
\hline $23 X-3,100-120$ & 175.30 & 2.0 & - & - & - & 1.48 & - & 563 & 561 & 1.36 & 577 & 13.2 & 8.93 & 45.0 & - \\
\hline \multicolumn{16}{|l|}{ 344-U1412B- } \\
\hline $4 \mathrm{X}-2,100-120$ & 167.97 & 5.2 & 32.0 & - & - & - & - & 548 & 553 & 1.08 & 328 & 7.02 & 6.31 & 31.1 & - \\
\hline $5 X-1,120-140$ & 176.40 & 32.0 & 33.0 & 7.77 & 18.9 & 0.46 & - & 554 & 560 & 1.10 & 442 & 9.52 & 8.35 & 38.9 & 6.24 \\
\hline $6 \mathrm{X}-2,99-125$ & 186.74 & 30.0 & 33.0 & 7.79 & 18.19 & 0.61 & - & 554 & 556 & 1.12 & 414 & 8.07 & 8.01 & 33.9 & 5.75 \\
\hline $7 X-2,51-73$ & 196.02 & 50.0 & 32.5 & 7.76 & 16.09 & 0.61 & - & 555 & 561 & 1.15 & 378 & 10.2 & 9.14 & 35.4 & 6.03 \\
\hline \multicolumn{16}{|l|}{ 344-U1412C- } \\
\hline $4 \mathrm{R}-\mathrm{CC}$ & & 3.5 & 31.5 & - & - & 2.96 & - & 555 & - & 1.29 & 480 & 9.07 & 9.48 & 31.2 & - \\
\hline $5 R-1,0-36$ & 328.80 & 11.0 & 31.0 & - & - & 0.31 & - & 560 & 560 & 1.53 & 468 & 8.44 & 10.3 & 26.8 & 3.38 \\
\hline $6 \mathrm{R}-1,9-20$ & 338.59 & 7.0 & 30.5 & - & - & 0.15 & - & 550 & 553 & 1.90 & 498 & 8.22 & 12.4 & 28.2 & 3.49 \\
\hline 7R-2, 96-112 & 350.31 & 20.0 & 32.0 & 7.84 & 6.42 & 0.51 & - & 558 & 560 & 2.20 & 475 & 9.12 & 12.4 & 24.0 & 3.91 \\
\hline $8 R-1,121-148$ & 359.11 & 8.0 & 30.5 & - & - & 0.51 & - & 541 & 546 & 2.23 & 440 & 7.79 & 11.2 & 23.6 & 4.04 \\
\hline $8 R-5,59-95$ & 364.13 & 35.0 & 31.0 & 7.93 & 3.86 & 0.36 & - & 552 & 559 & 2.42 & 492 & 9.58 & 10.8 & 22.2 & 5.31 \\
\hline $9 R-2,58-88$ & 369.02 & 35.0 & 31.0 & 7.74 & 4.41 & 0.26 & - & 544 & 553 & 2.47 & 486 & 9.98 & 11.2 & 22.4 & 6.10 \\
\hline \multicolumn{16}{|l|}{ 344-U1412D- } \\
\hline $2 \mathrm{R}-2,78-101$ & 352.18 & 28.0 & 32 & 7.63 & 7.31 & 0.20 & - & 561 & 552 & 2.56 & 484 & 9.85 & 9.67 & 21.8 & 5.35 \\
\hline $2 \mathrm{R}-5,106-131$ & 356.47 & 29.0 & 31.5 & 7.85 & 6.53 & 0.15 & - & 562 & 552 & 2.60 & 490 & 10.4 & 9.06 & 19.9 & 6.57 \\
\hline $3 R-3,61-86$ & 362.02 & 33.0 & 31.5 & 7.62 & 8.02 & 0.51 & - & 555 & 599 & 2.52 & 488 & 10.6 & 8.74 & 18.8 & 7.55 \\
\hline Drilling fluid & & & & & & 25.64 & & 496 & 492 & 0.76 & 404 & 8.65 & 8.97 & 46.1 & 0.00 \\
\hline
\end{tabular}

$\mathrm{IC}=$ ion chromatograph, ICP $=$ inductively coupled plasma-atomic emission spectroscopy, titr. $=$ titration, $-=$ not measured. 
Table T7. Uncorrected pore fluid minor element concentrations, Site U1412.

\begin{tabular}{|c|c|c|c|c|c|c|c|c|}
\hline $\begin{array}{l}\text { Core, section, } \\
\text { interval }(\mathrm{cm})\end{array}$ & $\begin{array}{l}\text { Depth } \\
\text { (mbsf) }\end{array}$ & $\begin{array}{c}B \\
(\mu \mathrm{M})\end{array}$ & $\begin{array}{c}\mathrm{Li} \\
(\mu \mathrm{M})\end{array}$ & $\begin{array}{c}\mathrm{Sr} \\
(\mu \mathrm{M})\end{array}$ & $\begin{array}{c}\mathrm{Ba} \\
(\mu \mathrm{M})\end{array}$ & $\begin{array}{c}\mathrm{Mn} \\
(\mu \mathrm{M})\end{array}$ & $\begin{array}{c}\mathrm{Si} \\
(\mu \mathrm{M})\end{array}$ & $\begin{array}{l}\mathrm{PO}_{4} \\
(\mu \mathrm{M})\end{array}$ \\
\hline \multicolumn{9}{|l|}{ 344-U1412A- } \\
\hline $1 \mathrm{H}-1,138-150$ & 1.44 & 576 & 25.8 & 82.9 & 0.344 & 1.3 & 501 & 9.3 \\
\hline $1 \mathrm{H}-2,138-150$ & 2.94 & 497 & 22.1 & 79.8 & 0.250 & 0.0 & 514 & 19.6 \\
\hline $1 \mathrm{H}-4,98-110$ & 5.54 & 536 & 22.7 & 79.3 & 0.241 & 0.0 & 581 & 28.6 \\
\hline $2 \mathrm{H}-2,138-150$ & 8.84 & 474 & 20.0 & 68.2 & 0.664 & 0.0 & 627 & 47.1 \\
\hline $2 \mathrm{H}-6,72-84$ & 14.20 & 508 & 12.7 & 71.2 & 10.8 & 0.0 & 655 & 88.9 \\
\hline $2 \mathrm{H}-7,106-118$ & 15.38 & 571 & 10.7 & 75.6 & 12.5 & 0.0 & 622 & 102 \\
\hline $3 \mathrm{H}-1,138-150$ & 16.84 & 537 & 9.14 & 75.2 & 12.9 & 0.0 & 625 & 102 \\
\hline $3 \mathrm{H}-3,138-150$ & 19.84 & 502 & 5.96 & 80.1 & 15.7 & 0.36 & 530 & 117 \\
\hline $3 \mathrm{H}-5,138-150$ & 22.84 & 531 & 5.91 & 79.9 & 16.9 & 0.37 & 537 & 121 \\
\hline $4 \mathrm{H}-2,138-150$ & 27.84 & 453 & 9.31 & 79.0 & 21.1 & 0.46 & 504 & 99.4 \\
\hline $4 \mathrm{H}-4,138-150$ & 30.87 & 383 & 10.9 & 81.7 & 25.8 & 1.2 & 545 & 102 \\
\hline $5 \mathrm{H}-3,118-135$ & 36.19 & 389 & 12.3 & 85.6 & 33.0 & 2.2 & 544 & 85.6 \\
\hline $5 \mathrm{H}-7,133-150$ & 40.50 & 377 & 13.1 & 84.8 & 36.6 & 1.8 & 534 & 86.6 \\
\hline $6 \mathrm{H}-2,132-149$ & 44.87 & 370 & 12.3 & 87.1 & 37.5 & 1.6 & 512 & 72.6 \\
\hline $6 \mathrm{H}-4,134-151$ & 47.91 & 292 & 12.7 & 82.8 & 36.9 & 0.97 & 446 & 57.4 \\
\hline 7H-2, 128-145 & 51.89 & 392 & 13.8 & 88.4 & 35.6 & 1.8 & 594 & 91.3 \\
\hline 7H-5, 103-120 & 55.89 & 359 & 14.4 & 88.3 & 34.5 & 1.5 & 580 & 82.6 \\
\hline $8 \mathrm{H}-1,129-151$ & 58.90 & 356 & 13.7 & 88.6 & 30.0 & 1.4 & 579 & 79.2 \\
\hline $8 \mathrm{H}-3,100-122$ & 61.62 & 398 & 12.4 & 88.1 & 30.0 & 0.48 & 535 & 92.3 \\
\hline $9 \mathrm{H}-2,128-150$ & 65.76 & 390 & 13.1 & 92.7 & 29.0 & 0.54 & 530 & 97.4 \\
\hline $9 \mathrm{H}-6,135-157$ & 70.54 & 333 & 15.1 & 84.4 & 28.6 & 0.44 & 451 & 57.5 \\
\hline $10 \mathrm{H}-1,128-150$ & 73.59 & 329 & 17.6 & 87.3 & 31.7 & 0.58 & 580 & 62.7 \\
\hline $10 \mathrm{H}-5,134-156$ & 79.59 & 304 & 17.4 & 88.1 & 35.9 & 1.6 & 535 & 52.2 \\
\hline $11 \mathrm{H}-2,130-152$ & 83.93 & 312 & 16.0 & 83.7 & 38.8 & 1.7 & 553 & 58.8 \\
\hline $12 \mathrm{H}-1,115-137$ & 87.56 & 302 & 15.3 & 83.6 & 34.2 & 2.4 & 596 & 58.9 \\
\hline $12 \mathrm{H}-3,94-116$ & 90.13 & 288 & 16.8 & 86.6 & 37.5 & 2.1 & 586 & 51.0 \\
\hline $13 \mathrm{H}-2,124-146$ & 93.62 & 271 & 17.7 & 79.6 & 30.5 & 0.58 & 541 & 39.8 \\
\hline $14 \mathrm{H}-2,80-102$ & 98.22 & 285 & 17.9 & 83.6 & 26.0 & 0.55 & 399 & 29.9 \\
\hline $15 \mathrm{H}-2,93-115$ & 106.75 & 239 & 23.0 & 85.1 & 36.8 & 0.50 & 612 & 33.6 \\
\hline $16 \mathrm{X}-2,126-148$ & 110.98 & 219 & 24.9 & 85.1 & 42.5 & 1.2 & 585 & 22.2 \\
\hline 20X-4, 131-151 & 148.01 & - & - & - & - & - & - & - \\
\hline $22 X-1,131-151$ & 162.91 & 134 & 37.4 & 91.6 & 44.0 & 1.6 & 609 & - \\
\hline $22 X-3,68-88$ & 165.01 & 70.0 & 35.2 & 92.4 & 47.3 & 1.2 & 483 & - \\
\hline $23 X-3,100-120$ & 175.30 & 113 & 40.8 & 92.4 & 37.7 & 0.92 & 373 & - \\
\hline \multicolumn{9}{|l|}{ 344-U1412B- } \\
\hline $4 X-2,100-120$ & 167.97 & 109 & 53.1 & 92.6 & 58.1 & 2.3 & 589 & - \\
\hline $5 X-1,120-140$ & 176.40 & 112 & 58.3 & 107 & 68.5 & 1.5 & 518 & - \\
\hline $6 \mathrm{X}-2,99-125$ & 186.74 & 132 & 61.4 & 121 & 79.4 & 3.0 & 625 & - \\
\hline $7 X-2,51-73$ & 196.02 & 128 & 60.8 & 139 & 113 & 3.0 & 639 & - \\
\hline \multicolumn{9}{|l|}{ 344-U1412C- } \\
\hline $4 \mathrm{R}-\mathrm{CC}$ & 321.50 & 376 & 27.6 & 226 & 59.1 & 1.6 & 986 & - \\
\hline $5 R-1,0-36$ & 328.80 & 334 & - & 311 & 591 & 1.6 & 769 & - \\
\hline $6 \mathrm{R}-1,9-20$ & 338.59 & 141 & 21.8 & 307 & 515 & 3.5 & 159 & - \\
\hline 7R-2, 96-112 & 350.31 & 144 & 82.8 & 266 & 215 & 6.8 & 467 & - \\
\hline $8 \mathrm{R}-1,121-148$ & 359.11 & 152 & 109 & 247 & 194 & 3.8 & 173 & - \\
\hline $8 R-5,59-95$ & 364.13 & 159 & 108 & 248 & 298 & 2.1 & 206 & - \\
\hline $9 \mathrm{R}-2,58-88$ & 369.02 & 279 & 97.9 & 260 & 390 & 5.1 & 356 & - \\
\hline \multicolumn{9}{|l|}{ 344-U1412D- } \\
\hline 2R-2, 78-101 & 352.18 & 215 & 91.9 & 227 & 264 & 2.2 & 313 & - \\
\hline $2 \mathrm{R}-5,106-131$ & 356.47 & 261 & 71.9 & 235 & 366 & 1.8 & 392 & - \\
\hline $3 R-3,61-86$ & 362.02 & 492 & 69.0 & 239 & 317 & 2.8 & 745 & - \\
\hline Drilling fluid & & 322 & 18.0 & 76 & 0 & 0.0 & 66 & 0 \\
\hline
\end{tabular}

$-=$ not measured. 
Table T8. Sulfate-corrected pore fluid major element concentrations, Site U1412.

\begin{tabular}{|c|c|c|c|c|c|c|c|c|c|c|c|c|}
\hline $\begin{array}{l}\text { Core, section, } \\
\text { interval }(\mathrm{cm})\end{array}$ & $\begin{array}{l}\text { Depth } \\
\text { (mbsf) }\end{array}$ & Salinity & $\mathrm{pH}$ & $\begin{array}{l}\text { Alkalinity } \\
(\mathrm{mM})\end{array}$ & $\begin{array}{l}\mathrm{Cl} \mathrm{IC} \\
(\mathrm{mM})\end{array}$ & $\begin{array}{l}\text { Cl titr. } \\
(\mathrm{mM})\end{array}$ & $\begin{array}{c}\mathrm{Br} \\
(\mathrm{mM})\end{array}$ & $\begin{array}{l}\mathrm{Na} \\
(\mathrm{mM})\end{array}$ & $\begin{array}{c}\mathrm{K} \\
(\mathrm{mM})\end{array}$ & $\begin{array}{c}\mathrm{Ca} \\
(\mathrm{mM})\end{array}$ & $\begin{array}{l}\mathrm{Mg} \\
(\mathrm{mM})\end{array}$ & $\begin{array}{l}\mathrm{NH}_{4} \\
(\mathrm{mM})\end{array}$ \\
\hline \multicolumn{13}{|l|}{ 344-U1412A- } \\
\hline $1 \mathrm{H}-1,138-150$ & 1.44 & 35.0 & 8.07 & 4.31 & 559 & 553 & 0.86 & 461 & 12.0 & 9.13 & 47.8 & 0.31 \\
\hline $1 \mathrm{H}-2,138-150$ & 2.94 & 35.0 & 7.67 & 5.78 & 551 & 554 & 0.86 & 454 & 11.6 & 8.41 & 46.8 & 0.54 \\
\hline $1 \mathrm{H}-4,98-110$ & 5.54 & 34.5 & 7.82 & 10.03 & 559 & 557 & 0.88 & 465 & 11.7 & 7.27 & 46.3 & 1.05 \\
\hline $2 \mathrm{H}-2,138-150$ & 8.84 & 34.5 & 7.97 & 16.15 & 559 & 559 & 0.90 & 456 & 11.7 & 5.34 & 43.0 & 1.56 \\
\hline $2 \mathrm{H}-6,72-84$ & 14.20 & 34.0 & 7.96 & 26.09 & 562 & 560 & 0.93 & 453 & 11.3 & 3.19 & 40.2 & 2.44 \\
\hline $2 \mathrm{H}-7,106-118$ & 15.38 & 34.0 & 7.97 & 25.18 & 559 & 562 & 0.92 & 456 & 11.4 & 3.27 & 40.4 & - \\
\hline $3 \mathrm{H}-1,138-150$ & 16.84 & 34.1 & 8.04 & 27.17 & 565 & 564 & 0.94 & 446 & 11.1 & 3.78 & 40.6 & 3.10 \\
\hline $3 \mathrm{H}-3,138-150$ & 19.84 & 33.5 & 7.96 & 29.21 & 562 & 560 & 0.95 & 461 & 11.3 & 3.76 & 41.4 & 3.31 \\
\hline $3 \mathrm{H}-5,138-150$ & 22.84 & 33.5 & 7.78 & 28.19 & 565 & 562 & 0.97 & 462 & 12.0 & 3.87 & 40.4 & 4.16 \\
\hline $4 \mathrm{H}-2,138-150$ & 27.84 & 33.5 & 7.90 & 32.11 & 563 & 561 & 1.02 & 459 & 11.9 & 4.22 & 40.7 & 5.76 \\
\hline $4 \mathrm{H}-4,138-150$ & 30.87 & 33.5 & 7.76 & 34.80 & 561 & 560 & 1.04 & 467 & 11.9 & 4.40 & 42.2 & 5.49 \\
\hline $5 \mathrm{H}-3,118-135$ & 36.19 & 34.6 & 7.74 & 39.20 & 564 & 562 & 1.08 & 474 & 12.2 & 4.84 & 43.2 & 6.68 \\
\hline $5 \mathrm{H}-7,133-150$ & 40.50 & 34.5 & 7.68 & 40.33 & 565 & 566 & 1.12 & 459 & 12.2 & 4.83 & 42.2 & 7.17 \\
\hline $6 \mathrm{H}-2,132-149$ & 44.87 & 34.0 & 7.85 & 42.76 & 563 & 561 & 1.14 & 466 & 12.5 & 5.00 & 43.3 & 7.69 \\
\hline $6 \mathrm{H}-4,134-151$ & 47.91 & 34.5 & 7.88 & 40.54 & 566 & 562 & 1.16 & 468 & 13.1 & 4.63 & 42.1 & 8.16 \\
\hline 7H-2, 128-145 & 51.89 & 34.6 & 7.71 & 44.15 & 566 & 563 & 1.18 & 471 & 12.4 & 5.10 & 44.3 & 8.22 \\
\hline $7 \mathrm{H}-5,103-120$ & 55.89 & 34.5 & 7.00 & 44.07 & 565 & 562 & 1.19 & 472 & 12.4 & 5.07 & 44.8 & 8.21 \\
\hline $8 \mathrm{H}-1,129-151$ & 58.90 & 34.6 & 7.79 & 43.22 & 565 & 564 & 1.20 & 474 & 12.4 & 4.87 & 44.0 & 8.66 \\
\hline $8 \mathrm{H}-3,100-122$ & 61.62 & 34.0 & 7.66 & 43.37 & 556 & 554 & 1.20 & 462 & 12.4 & 4.91 & 43.5 & 8.35 \\
\hline $9 \mathrm{H}-2,128-150$ & 65.76 & 34.5 & 7.77 & 43.73 & 566 & 562 & 1.24 & 459 & 12.1 & 4.83 & 43.6 & 8.64 \\
\hline $9 \mathrm{H}-6,135-157$ & 70.54 & 33.5 & 7.94 & 41.06 & 548 & 544 & 1.22 & 456 & 12.4 & 4.43 & 41.7 & 8.59 \\
\hline $10 \mathrm{H}-1,128-150$ & 73.59 & 34.5 & 7.81 & 42.02 & 565 & 566 & 1.28 & 471 & 12.3 & 4.56 & 43.9 & 8.82 \\
\hline $10 \mathrm{H}-5,134-156$ & 79.59 & 34.5 & 7.86 & 40.52 & 566 & 564 & 1.28 & 479 & 12.7 & 4.90 & 44.1 & 9.19 \\
\hline $11 \mathrm{H}-2,130-152$ & 83.93 & 33.0 & 7.86 & 40.74 & 546 & 540 & 1.26 & 458 & 11.8 & 5.10 & 41.9 & 8.92 \\
\hline $12 \mathrm{H}-1,115-137$ & 87.56 & 34.6 & 7.78 & 42.01 & 564 & 563 & 1.31 & 466 & 11.2 & 5.37 & 43.8 & 9.07 \\
\hline $12 \mathrm{H}-3,94-116$ & 90.13 & 34.5 & 7.84 & 40.50 & 568 & 566 & 1.31 & 463 & 11.7 & 5.11 & 42.7 & 9.27 \\
\hline $13 \mathrm{H}-2,124-146$ & 93.62 & 34.0 & 7.70 & 36.07 & 567 & 568 & 1.32 & 473 & 11.6 & 4.56 & 42.4 & 8.90 \\
\hline $14 \mathrm{H}-2,80-102$ & 98.22 & 34.5 & 7.78 & 34.53 & 568 & 568 & 1.34 & 455 & 11.2 & 4.81 & 40.3 & 9.17 \\
\hline $15 \mathrm{H}-2,93-115$ & 106.75 & 33.5 & 7.76 & 32.43 & 571 & 564 & 1.37 & 483 & 12.5 & 5.23 & 40.5 & 9.34 \\
\hline $16 \mathrm{X}-2,126-148$ & 110.98 & 33.5 & - & - & 564 & 561 & 1.35 & 469 & 11.7 & 5.48 & 40.1 & 9.34 \\
\hline 20X-4, 131-151 & 148.01 & - & - & - & 559 & 555 & 1.38 & 362 & 7.65 & 5.24 & 31.6 & - \\
\hline $22 X-1,131-151$ & 162.91 & - & - & - & 570 & 572 & 1.38 & 373 & 9.08 & 5.27 & 30.9 & - \\
\hline $22 X-3,68-88$ & 165.01 & - & - & - & 572 & 566 & 1.41 & 444 & 10.8 & 5.98 & 34.7 & - \\
\hline $23 X-3,100-120$ & 175.30 & - & - & - & 567 & 565 & 1.40 & 587 & 13.4 & 8.93 & 44.9 & - \\
\hline \multicolumn{13}{|l|}{ 344-U1412B- } \\
\hline $4 X-2,100-120$ & 167.97 & 32.0 & - & - & 549 & 554 & 1.09 & - & 6.99 & 6.27 & 30.8 & - \\
\hline $5 X-1,120-140$ & 176.40 & 33.1 & 7.76 & 19.31 & 556 & 562 & 1.11 & 442 & 9.54 & 8.33 & 38.7 & 6.39 \\
\hline $6 \mathrm{X}-2,99-125$ & 186.74 & 33.1 & 7.78 & 18.58 & 555 & 557 & 1.13 & 415 & 8.05 & 7.98 & 33.6 & 5.89 \\
\hline $7 X-2,51-73$ & 196.02 & 32.5 & 7.75 & 16.38 & 556 & 563 & 1.15 & 378 & 10.3 & 9.14 & 35.1 & 6.15 \\
\hline \multicolumn{13}{|l|}{ 344-U1412C- } \\
\hline $4 \mathrm{R}-\mathrm{CC}$ & 321.47 & 31.6 & - & - & 562 & - & 1.36 & 311 & 9.13 & 9.54 & 29.3 & - \\
\hline $5 R-1,0-36$ & 328.80 & 31.0 & - & - & 561 & 561 & 1.54 & 328 & 8.43 & 10.3 & 26.5 & 3.42 \\
\hline $6 \mathrm{R}-1,9-20$ & 338.59 & 30.5 & - & - & 551 & 553 & 1.91 & 338 & 8.22 & 12.4 & 28.1 & 3.51 \\
\hline 7R-2, 96-112 & 350.31 & 32.0 & 7.83 & 6.51 & 560 & 561 & 2.23 & 349 & 9.13 & 12.4 & 23.6 & 3.99 \\
\hline $8 R-1,121-148$ & 359.11 & 30.5 & - & - & 542 & 547 & 2.26 & 358 & 7.78 & 11.3 & 23.1 & 4.13 \\
\hline $8 R-5,59-95$ & 364.13 & 31.0 & 7.93 & 3.89 & 553 & 560 & 2.44 & 364 & 9.60 & 10.8 & 21.8 & 5.38 \\
\hline $9 R-2,58-88$ & 369.02 & 31.0 & 7.74 & 4.43 & 545 & 554 & 2.49 & 369 & 10.0 & 11.2 & 22.2 & 6.17 \\
\hline \multicolumn{13}{|l|}{ 344-U1412D- } \\
\hline 2R-2, 78-101 & 352.18 & - & - & - & - & - & - & 485 & 9.86 & 9.67 & 21.6 & - \\
\hline 2R-5, 106-131 & 356.47 & - & - & - & - & - & - & 490 & 10.4 & 9.06 & 19.8 & - \\
\hline $3 R-3,61-86$ & 362.02 & - & - & - & - & - & - & 489 & 10.6 & 8.73 & 18.2 & - \\
\hline Drilling fluid & & & & & & & & & & & & \\
\hline
\end{tabular}

IC $=$ ion chromatograph, titr. = titration, $-=$ not measured. 
Table T9. Minor element concentrations corrected for drill fluid contamination, Site U1412.

\begin{tabular}{|c|c|c|c|c|c|c|c|}
\hline $\begin{array}{l}\text { Core, section, } \\
\text { interval }(\mathrm{cm})\end{array}$ & $\begin{array}{l}\text { Depth } \\
\text { (mbsf) }\end{array}$ & $\begin{array}{c}B \\
(\mu \mathrm{M})\end{array}$ & $\begin{array}{c}\mathrm{Li} \\
(\mu \mathrm{M})\end{array}$ & $\begin{array}{c}\mathrm{Sr} \\
(\mu \mathrm{M})\end{array}$ & $\begin{array}{c}\mathrm{Ba} \\
(\mu \mathrm{M})\end{array}$ & $\begin{array}{c}\mathrm{Mn} \\
(\mu \mathrm{M})\end{array}$ & $\begin{array}{c}\mathrm{Si} \\
(\mu \mathrm{M})\end{array}$ \\
\hline \multicolumn{8}{|l|}{ 344-U1412A- } \\
\hline $1 \mathrm{H}-1,138-150$ & 1.4 & 576 & 25.8 & 82.9 & 0.34 & 1.3 & 501 \\
\hline $1 \mathrm{H}-2,138-150$ & 2.9 & 497 & 22.1 & 79.8 & 0.25 & 0.0 & 514 \\
\hline $1 \mathrm{H}-4,98-110$ & 5.5 & 536 & 22.7 & 79.3 & 0.24 & 0.0 & 581 \\
\hline $2 \mathrm{H}-2,138-150$ & 8.8 & 474 & 20.0 & 68.2 & 0.66 & 0.0 & 627 \\
\hline $2 \mathrm{H}-6,72-84$ & 14.2 & 508 & 12.7 & 71.2 & 10.8 & 0.0 & 655 \\
\hline $2 \mathrm{H}-7,106-118$ & 15.4 & 572 & 10.7 & 75.6 & 12.6 & 0.0 & 623 \\
\hline $3 \mathrm{H}-1,138-150$ & 16.8 & 541 & 9.0 & 75.2 & 13.1 & 0.0 & 635 \\
\hline $3 \mathrm{H}-3,138-150$ & 19.8 & 503 & 5.9 & 80.2 & 15.9 & 0.36 & 533 \\
\hline $3 \mathrm{H}-5,138-150$ & 22.8 & 532 & 5.9 & 79.9 & 17.0 & 0.37 & 538 \\
\hline $4 \mathrm{H}-2,138-150$ & 27.8 & 454 & 9.3 & 79.0 & 21.2 & 0.46 & 506 \\
\hline $4 \mathrm{H}-4,138-150$ & 30.9 & 383 & 10.8 & 81.7 & 25.9 & 1.2 & 546 \\
\hline $5 \mathrm{H}-3,118-135$ & 36.2 & 390 & 12.2 & 85.7 & 33.5 & 2.3 & 552 \\
\hline $5 \mathrm{H}-7,133-150$ & 40.5 & 377 & 13.1 & 84.8 & 36.7 & 1.8 & 535 \\
\hline $6 \mathrm{H}-2,132-149$ & 44.9 & & & & & & \\
\hline $6 \mathrm{H}-4,134-151$ & 47.9 & 292 & 12.7 & 82.8 & 37.0 & 0.97 & 446 \\
\hline 7H-2, 128-145 & 51.9 & 393 & 13.7 & 88.6 & 36.2 & 1.8 & 603 \\
\hline 7H-5, 103-120 & 55.9 & 359 & 14.4 & 88.3 & 34.6 & 1.5 & 581 \\
\hline $8 \mathrm{H}-1,129-151$ & 58.9 & 358 & 13.6 & 89.1 & 31.1 & 1.5 & 597 \\
\hline $8 \mathrm{H}-3,100-122$ & 61.6 & 398 & 12.4 & 88.1 & 30.0 & 0.48 & 535 \\
\hline $9 \mathrm{H}-2,128-150$ & 65.8 & 390 & 13.1 & 92.7 & 29.1 & 0.54 & 531 \\
\hline $9 \mathrm{H}-6,135-157$ & 70.5 & 333 & 15.1 & 84.4 & 28.6 & 0.44 & 452 \\
\hline $10 \mathrm{H}-1,128-150$ & 73.6 & 329 & 17.6 & 87.4 & 32.1 & 0.58 & 585 \\
\hline $10 \mathrm{H}-5,134-156$ & 79.6 & 304 & 17.4 & 88.1 & 35.9 & 1.6 & 535 \\
\hline $11 \mathrm{H}-2,130-152$ & 83.9 & 312 & 16.0 & 83.7 & 39.0 & 1.7 & 555 \\
\hline $12 \mathrm{H}-1,115-137$ & 87.6 & 301 & 15.2 & 83.8 & 35.0 & 2.4 & 608 \\
\hline $12 \mathrm{H}-3,94-116$ & 90.1 & 288 & 16.7 & 86.7 & 37.9 & 2.1 & 593 \\
\hline $13 \mathrm{H}-2,124-146$ & 93.6 & 271 & 17.7 & 79.7 & 30.7 & 0.58 & 544 \\
\hline $14 \mathrm{H}-2,80-102$ & 98.2 & 285 & 17.9 & 83.7 & 26.2 & 0.55 & 401 \\
\hline $15 \mathrm{H}-2,93-115$ & 106.8 & 239 & 23.1 & 85.1 & 37.0 & 0.50 & 614 \\
\hline $16 X-2,126-148$ & 111.0 & 218 & 24.9 & 85.1 & 42.8 & 1.2 & 589 \\
\hline 20X-4, 131-151 & 148.0 & & & & & & \\
\hline $22 X-1,131-151$ & 162.9 & 114 & 39.4 & 93.3 & 48.5 & 1.8 & 665 \\
\hline $22 X-3,68-88$ & 165.0 & 62 & 35.8 & 92.9 & 48.9 & 1.3 & 497 \\
\hline $23 X-3,100-120$ & 175.3 & 100 & 42.2 & 93.5 & 40.0 & 0.98 & 392 \\
\hline \multicolumn{8}{|l|}{ 344-U1412B- } \\
\hline $4 X-2,100-120$ & 168.0 & & & & & & \\
\hline $5 X-1,120-140$ & 176.4 & 108 & 59.1 & 108 & 69.7 & 1.6 & 526 \\
\hline $6 \mathrm{X}-2,99-125$ & 186.7 & 127 & 62.4 & 122 & 81.3 & 3.1 & 639 \\
\hline $7 X-2,51-73$ & 196.0 & 123 & 61.9 & 140 & 115 & 3.1 & 653 \\
\hline \multicolumn{8}{|l|}{ 344-U1412C- } \\
\hline $4 \mathrm{R}-\mathrm{CC}$ & 321.5 & 383 & 28.8 & 246 & 66.8 & 1.9 & 1100 \\
\hline $5 R-1,0-36$ & 328.8 & 334 & & 314 & 598 & 1.6 & 778 \\
\hline $6 \mathrm{R}-1,9-20$ & 338.59 & 140 & 21.8 & 309 & 518 & 3.5 & 160 \\
\hline 7R-2, 96-112 & 350.31 & 140 & 84.1 & 270 & 219 & 6.9 & 475 \\
\hline $8 R-1,121-148$ & 359.11 & 148 & 111.2 & 250 & 198 & 3.9 & 175 \\
\hline $8 R-5,59-95$ & 364.13 & 157 & 109.3 & 251 & 302 & 2.1 & 208 \\
\hline $9 R-2,58-88$ & 369.02 & 279 & 98.7 & 262 & 394 & 5.2 & 359 \\
\hline \multicolumn{8}{|l|}{ 344-U1412D- } \\
\hline 2R-2, 78-101 & 352.18 & 213 & 93.4 & 231 & 270 & 2.2 & 318 \\
\hline $2 \mathrm{R}-5,106-131$ & 356.47 & 260 & 72.6 & 238 & 372 & 1.8 & 396 \\
\hline $3 R-3,61-86$ & 362.02 & 494 & 69.5 & 241 & 320 & 2.9 & 752 \\
\hline
\end{tabular}


Table T10. Concentrations of hydrocarbon gases in headspace gas samples, Site U1412.

\begin{tabular}{|c|c|c|c|c|c|}
\hline $\begin{array}{l}\text { Core, section, } \\
\text { interval }(\mathrm{cm})\end{array}$ & $\begin{array}{l}\text { Depth } \\
\text { (mbsf) }\end{array}$ & $\begin{array}{l}\text { Methane } \\
\text { (ppmv) }\end{array}$ & $\begin{array}{l}\text { Ethane } \\
\text { (ppmv) }\end{array}$ & $\begin{array}{l}\text { Propane } \\
\text { (ppmv) }\end{array}$ & $\mathrm{C}_{1} / \mathrm{C}_{2+}$ \\
\hline \multicolumn{6}{|l|}{ 344-U1412A- } \\
\hline $1 \mathrm{H}-2,0-5$ & 1.50 & 4.25 & ND & ND & - \\
\hline $1 \mathrm{H}-3,0-5$ & 3.00 & 6.15 & ND & ND & - \\
\hline $1 \mathrm{H}-4,93-98$ & 5.43 & 16.3 & ND & ND & - \\
\hline $2 \mathrm{H}-3,0-5$ & 8.90 & 59.4 & 0.420 & ND & 141 \\
\hline $2 \mathrm{H}-6,67-72$ & 14.09 & 8,500 & 1.44 & ND & 5,920 \\
\hline $2 \mathrm{H}-7,101-106$ & 15.27 & 8,410 & 0.855 & ND & 9,830 \\
\hline $3 \mathrm{H}-2,0-5$ & 16.90 & 3,880 & 0.602 & ND & 6,450 \\
\hline $3 \mathrm{H}-3,0-5$ & 18.40 & 14,300 & 0.850 & ND & 9,550 \\
\hline $3 \mathrm{H}-6,145-150$ & 24.35 & 7,290 & 0.404 & ND & 18,000 \\
\hline $4 \mathrm{H}-3,0-5$ & 27.90 & 7,690 & 0.612 & ND & 7,220 \\
\hline $4 \mathrm{H}-5,0-5$ & 30.93 & 7,090 & 0.492 & ND & 6,380 \\
\hline $5 \mathrm{H}-4,0-5$ & 36.27 & 10,900 & 0.645 & ND & 16,900 \\
\hline $5 \mathrm{H}-7,128-133$ & 40.36 & 3,960 & ND & ND & - \\
\hline $6 \mathrm{H}-3,0-5$ & 44.95 & 7,470 & 0.669 & ND & 5,220 \\
\hline $6 \mathrm{H}-5,0-5$ & 47.99 & 268 & ND & ND & - \\
\hline $7 \mathrm{H}-3,0-5$ & 51.97 & 1,300 & ND & ND & - \\
\hline $7 \mathrm{H}-6,0-5$ & 55.97 & 406 & ND & ND & 813 \\
\hline $8 \mathrm{H}-2,0-5$ & 59.01 & 3,760 & ND & ND & - \\
\hline $8 \mathrm{H}-4,0-5$ & 61.73 & 734 & ND & ND & - \\
\hline $9 \mathrm{H}-3,0-5$ & 65.87 & 893 & ND & ND & - \\
\hline $9 \mathrm{H}-7,0-5$ & 70.61 & 5,780 & 0.692 & ND & 8,360 \\
\hline $10 \mathrm{H}-2,0-5$ & 73.70 & 2,860 & ND & ND & - \\
\hline $10 \mathrm{H}-6,0-5$ & 79.70 & 10,500 & 0.979 & ND & 7,540 \\
\hline $11 \mathrm{H}-3,0-5$ & 84.04 & 5,490 & ND & ND & - \\
\hline $12 \mathrm{H}-2,0-5$ & 87.67 & 2,820 & 0.825 & ND & 3,420 \\
\hline $12 \mathrm{H}-4,0-5$ & 90.24 & 3,590 & 0.806 & ND & 4,460 \\
\hline $13 \mathrm{H}-3,0-5$ & 93.70 & 755 & ND & ND & - \\
\hline $14 \mathrm{H}-3,0-5$ & 98.33 & 4,850 & 0.828 & ND & 5,860 \\
\hline $15 \mathrm{H}-3,0-5$ & 106.86 & 6,090 & 1.89 & ND & 3,220 \\
\hline $16 X-3,0-5$ & 111.09 & 4,210 & 1.20 & ND & 3,500 \\
\hline $17 X-3,0-5$ & 115.94 & 6,520 & 0.995 & ND & 6,550 \\
\hline $17 X-6,0-5$ & 119.72 & 6,220 & 1.57 & 0.396 & 3,160 \\
\hline $18 X-1,0-5$ & 122.70 & 4,900 & 0.750 & ND & 6,530 \\
\hline $18 X-3,0-5$ & 125.41 & 4,580 & 1.27 & ND & 3,600 \\
\hline $19 X-2,0-5$ & 133.90 & 3,180 & ND & ND & - \\
\hline $19 X-4,0-5$ & 136.57 & 7,670 & 1.78 & ND & 4,300 \\
\hline $20 X-2,0-5$ & 143.60 & 5,070 & 1.28 & ND & 3,960 \\
\hline $20 X-5,0-5$ & 148.11 & 4,410 & 1.89 & ND & 2,330 \\
\hline $21 X-1,0-5$ & 151.80 & 31,400 & 3.58 & ND & 8,780 \\
\hline $21 X-3,0-5$ & 154.58 & 5,960 & 2.72 & ND & 2,190 \\
\hline $22 X-1,0-5$ & 162.76 & 7,070 & 1.83 & ND & 3,870 \\
\hline $22 X-2,0-5$ & 163.01 & 2,030 & 0.516 & ND & 3,930 \\
\hline $23 X-2,0-5$ & 172.70 & 2,650 & 1.52 & ND & 1,740 \\
\hline $23 X-4,0-5$ & 175.40 & 1,980 & 1.47 & ND & 1,350 \\
\hline $24 X-3,0-5$ & 182.59 & 26,800 & 3.06 & ND & 8,760 \\
\hline $25 X-3,0-5$ & 191.94 & 16,300 & 2.66 & ND & 6,130 \\
\hline \multicolumn{6}{|l|}{ 344-U1412B- } \\
\hline $1 \mathrm{H}-2,0-5$ & 1.50 & 218 & 1.67 & ND & 83.4 \\
\hline $1 \mathrm{H}-4,0-5$ & 4.50 & 10.3 & ND & ND & - \\
\hline $3 X-2,0-5$ & 156.62 & 6,050 & 6.28 & 0.625 & 641 \\
\hline $4 X-3,0-5$ & 168.17 & 10,600 & 2.47 & ND & 3,590 \\
\hline $5 X-2,0-5$ & 176.60 & 4,400 & 1.57 & ND & 2,080 \\
\hline $6 X-3,0-5$ & 187.00 & 5,440 & 0.88 & ND & 6,150 \\
\hline $7 X-3,0-5$ & 196.24 & 15,500 & 1.44 & 0.438 & 8,240 \\
\hline $8 X-1,0-5$ & 204.30 & 9,040 & 1.22 & ND & 7,430 \\
\hline $11 X-1,40-45$ & 228.90 & 15,000 & 8.64 & 2.52 & 1,340 \\
\hline $12 X-1,23-28$ & 233.63 & 17,100 & 11.9 & ND & 1,430 \\
\hline \multicolumn{6}{|l|}{ 344-U1412C- } \\
\hline 2R-1, 109-114 & 301.09 & 1,570 & 1.20 & ND & 1,310 \\
\hline $5 \mathrm{R}-1,31-36$ & 329.11 & 5,550 & 7.17 & ND & 775 \\
\hline 6R-1, 9-14 & 338.59 & 1,900 & 3.03 & ND & 628 \\
\hline $6 \mathrm{R}-6,0-5$ & 344.77 & 1,720 & 4.10 & ND & 420 \\
\hline 7R-2, 96-101 & 350.31 & 4,920 & 4.22 & ND & 1,170 \\
\hline $8 R-2,0-5$ & 359.38 & 3,380 & 3.34 & 3.08 & 527 \\
\hline $8 R-6,0-5$ & 364.49 & 9,560 & 3.10 & ND & 3,090 \\
\hline $9 \mathrm{R}-3,0-5$ & 369.32 & 4,760 & 3.72 & 0.509 & 1,130 \\
\hline
\end{tabular}

$-=$ incalculable. $\mathrm{ND}=$ not detected . 
Table T11. Concentrations of hydrocarbon and $\mathrm{CO}_{2}$ gases in the void gas, Hole U1412A and U1412B.

\begin{tabular}{|c|c|c|c|c|c|c|}
\hline $\begin{array}{l}\text { Core, section, } \\
\text { interval }(\mathrm{cm})\end{array}$ & $\begin{array}{l}\text { Depth } \\
\text { (mbsf) }\end{array}$ & $\begin{array}{c}\text { Methane } \\
\text { (ppmv) }\end{array}$ & $\begin{array}{l}\text { Ethane } \\
\text { (ppmv) }\end{array}$ & $\begin{array}{l}\text { Propane } \\
\text { (ppmv) }\end{array}$ & $\begin{array}{c}\mathrm{CO}_{2} \\
(\mathrm{ppmv})\end{array}$ & $\mathrm{C}_{1} / \mathrm{C}_{2+}$ \\
\hline \multicolumn{7}{|l|}{ 344-U1412A- } \\
\hline $4 \mathrm{H}-4,50-51$ & 29.93 & 820,000 & 16.4 & 1.6 & 5,190 & 45,700 \\
\hline $4 \mathrm{H}-6,50-51$ & 32.13 & 813,000 & 16.0 & 1.6 & 4,980 & 46,200 \\
\hline $5 \mathrm{H}-2,50-51$ & 33.93 & 781,000 & 14.9 & 1.4 & 3,020 & 48,000 \\
\hline $5 \mathrm{H}-4,50-51$ & 36.77 & 823,000 & 16.4 & 1.6 & 4,610 & 45,700 \\
\hline $5 \mathrm{H}-7,50-51$ & 39.58 & 837,000 & 16.5 & 1.6 & 4,000 & 46,200 \\
\hline $6 \mathrm{H}-1,50-51$ & 42.50 & 773,000 & 14.2 & 1.0 & 1,700 & 50,800 \\
\hline $7 \mathrm{H}-1,50-51$ & 50.00 & 841,000 & 16.8 & 1.2 & 3,390 & 46,600 \\
\hline $9 \mathrm{H}-2,50-51$ & 64.87 & 835,000 & 29.6 & 1.0 & 4,440 & 27,300 \\
\hline $9 \mathrm{H}-7,50-51$ & 71.11 & 849,000 & 56.1 & ND & 1,910 & 15,200 \\
\hline $10 \mathrm{H}-2,50-51$ & 74.20 & 848,000 & 24.6 & 1.2 & 4,610 & 32,800 \\
\hline $11 \mathrm{H}-4,50-51$ & 85.75 & 849,000 & 28.0 & 2.7 & 2,570 & 27,600 \\
\hline $12 \mathrm{H}-2,50-51$ & 88.17 & 842,000 & 54.5 & 2.2 & 3,500 & 14,900 \\
\hline $13 \mathrm{H}-4,50-51$ & 95.41 & 850,000 & 44.6 & 3.1 & 2,730 & 17,800 \\
\hline $14 \mathrm{H}-3,50-51$ & 98.83 & 838,000 & 53.4 & 4.3 & 5,070 & 14,500 \\
\hline $18 X-3,50-51$ & 125.91 & 788,000 & 62.9 & 10.9 & 11,100 & 10,700 \\
\hline $19 X-2,50-51$ & 134.40 & 838,000 & 58.6 & 7.0 & 6,420 & 12,800 \\
\hline $19 X-4,50-51$ & 137.07 & 822,000 & 63.4 & 8.9 & 10,500 & 11,400 \\
\hline $23 X-4,50-51$ & 175.90 & 844,000 & 85.3 & 7.2 & 6,830 & 9,120 \\
\hline \multicolumn{7}{|l|}{ 344-U1412B- } \\
\hline $6 X-3,50-51$ & 7.50 & 846 & 28.4 & 0.6 & 5,360 & 29,200 \\
\hline $7 X-3,50-51$ & 196.74 & 850,000 & 46.7 & 2.9 & 8,710 & 17,100 \\
\hline
\end{tabular}

$\mathrm{ND}=$ not detected 
Table T12. Total carbon (TC), inorganic carbon (IC), total organic carbon (TOC), calcium carbonate, total nitrogen $(\mathrm{TN})$, and $\mathrm{C} / \mathrm{N}$ ratios, Hole $\mathrm{U} 1412 \mathrm{~A}$.

\begin{tabular}{|c|c|c|c|c|c|c|c|}
\hline $\begin{array}{l}\text { Core, section, } \\
\text { interval }(\mathrm{cm})\end{array}$ & $\begin{array}{l}\text { Depth } \\
\text { (mbsf) }\end{array}$ & $\begin{array}{c}\mathrm{TC} \\
\text { (wt\%) }\end{array}$ & $\begin{array}{c}\text { IC } \\
(w t \%)\end{array}$ & $\begin{array}{l}\text { TOC } \\
\text { (wt\%) }\end{array}$ & $\begin{array}{l}\mathrm{CaCO}_{3} \\
\text { (wt\%) }\end{array}$ & $\begin{array}{c}\mathrm{TN} \\
(w t \%)\end{array}$ & $\begin{array}{l}\mathrm{C} / \mathrm{N} \\
\text { ratio }\end{array}$ \\
\hline \multicolumn{8}{|l|}{ 344-U1412A- } \\
\hline $1 \mathrm{H}-2 \mathrm{~W}, 133-134$ & 2.83 & 2.37 & 0.544 & 1.83 & 4.54 & 0.160 & 11.4 \\
\hline $1 \mathrm{H}-4 \mathrm{~W}, 2-3$ & 4.52 & 1.70 & 0.301 & 1.40 & 2.51 & 0.145 & 9.68 \\
\hline $1 \mathrm{H}-4 \mathrm{~W}, 93-94$ & 5.43 & 2.97 & 1.15 & 1.81 & 9.62 & 0.136 & 13.4 \\
\hline $2 \mathrm{H}-2 \mathrm{~W}, 136-138$ & 8.76 & 2.06 & 0.459 & 1.60 & 3.83 & 0.152 & 10.5 \\
\hline $2 \mathrm{H}-7 \mathrm{~W}, 27-28$ & 14.53 & 2.33 & 0.651 & 1.68 & 5.43 & 0.145 & 11.6 \\
\hline $2 \mathrm{H}-7 \mathrm{~W}, 106-107$ & 15.32 & 2.11 & 0.547 & 1.56 & 4.56 & 0.124 & 12.6 \\
\hline $3 \mathrm{H}-3 \mathrm{~W}, 137-138$ & 19.77 & 2.12 & 0.672 & 1.45 & 5.60 & 0.102 & 14.2 \\
\hline $3 \mathrm{H}-5 \mathrm{~W}, 137-138$ & 22.77 & 2.17 & 0.737 & 1.43 & 6.15 & 0.098 & 14.6 \\
\hline $3 \mathrm{H}-6 \mathrm{~W}, 53-54$ & 23.43 & 2.27 & 0.863 & 1.41 & 7.20 & 0.108 & 13.0 \\
\hline $4 \mathrm{H}-2 \mathrm{~W}, 135-136$ & 27.75 & 2.03 & 0.652 & 1.38 & 5.43 & 0.089 & 15.6 \\
\hline $4 \mathrm{H}-3 \mathrm{~W}, 94-95$ & 28.84 & 2.54 & 1.08 & 1.46 & 8.99 & 0.115 & 12.7 \\
\hline $4 \mathrm{H}-4 \mathrm{~W}, 138-139$ & 30.81 & 2.34 & 0.841 & 1.50 & 7.02 & 0.132 & 11.4 \\
\hline $5 \mathrm{H}-3 \mathrm{~W}, 118-120$ & 36.10 & 1.95 & 0.529 & 1.42 & 4.41 & 0.134 & 10.6 \\
\hline $5 \mathrm{H}-3 \mathrm{~W}, 63-64$ & 35.55 & 2.11 & 0.685 & 1.43 & 5.72 & 0.093 & 15.3 \\
\hline $5 \mathrm{H}-7 \mathrm{~W}, 131-132$ & 40.39 & 2.16 & 0.554 & 1.61 & 4.62 & 0.157 & 10.2 \\
\hline $6 \mathrm{H}-2 \mathrm{~W}, 130-131$ & 44.76 & 2.33 & 0.508 & 1.82 & 4.24 & 0.178 & 10.2 \\
\hline $6 \mathrm{H}-3 \mathrm{~W}, 70-71$ & 45.65 & 2.37 & 0.571 & 1.80 & 4.76 & 0.176 & 10.2 \\
\hline $6 \mathrm{H}-4 \mathrm{~W}, 131-132$ & 47.79 & 2.17 & 0.469 & 1.70 & 3.91 & 0.172 & 9.93 \\
\hline $7 \mathrm{H}-2 \mathrm{~W}, 62-63$ & 51.14 & 2.04 & 0.297 & 1.74 & 2.48 & 0.176 & 9.90 \\
\hline $7 \mathrm{H}-2 \mathrm{~W}, 27-28$ & 50.79 & 2.20 & 0.589 & 1.61 & 4.91 & 0.158 & 10.2 \\
\hline 7H-5W, 101-102 & 55.78 & 2.13 & 0.521 & 1.61 & 4.35 & 0.150 & 10.7 \\
\hline $8 \mathrm{H}-1 \mathrm{~W}, 27-28$ & 57.77 & 1.98 & 0.364 & 1.61 & 3.04 & 0.173 & 9.33 \\
\hline $8 \mathrm{H}-2 \mathrm{~W}, 87-88$ & 59.88 & 2.22 & 0.666 & 1.55 & 5.56 & 0.161 & 9.63 \\
\hline $8 \mathrm{H}-3 \mathrm{~W}, 98-99$ & 61.49 & 2.47 & 0.839 & 1.63 & 7.00 & 0.144 & 11.3 \\
\hline $9 \mathrm{H}-6 \mathrm{~W}, 131-133$ & 70.35 & 2.06 & 0.928 & 1.13 & 7.74 & 0.103 & 10.9 \\
\hline $10 \mathrm{H}-1 \mathrm{~W}, 126-127$ & 73.46 & 2.14 & 0.845 & 1.30 & 7.04 & 0.140 & 9.25 \\
\hline $10 \mathrm{H}-4 \mathrm{~W}, 133-134$ & 77.98 & 2.25 & 0.860 & 1.39 & 7.17 & 0.143 & 9.71 \\
\hline $10 \mathrm{H}-5 \mathrm{~W}, 33-34$ & 78.47 & 2.15 & 0.742 & 1.41 & 6.19 & 0.146 & 9.67 \\
\hline $11 \mathrm{H}-1 \mathrm{~W}, 139-140$ & 82.49 & 1.80 & 0.437 & 1.36 & 3.64 & 0.137 & 9.91 \\
\hline $11 \mathrm{H}-2 \mathrm{~W}, 128-129$ & 83.80 & 1.97 & 0.268 & 1.70 & 2.24 & 0.168 & 10.1 \\
\hline $12 \mathrm{H}-1 \mathrm{~W}, 112-113$ & 87.42 & 1.72 & 0.107 & 1.61 & 0.892 & 0.171 & 9.41 \\
\hline $12 \mathrm{H}-2 \mathrm{~W}, 137-138$ & 89.04 & 1.62 & 0.106 & 1.52 & 0.885 & 0.163 & 9.29 \\
\hline $12 \mathrm{H}-3 \mathrm{~W}, 92-93$ & 90.00 & 1.87 & 0.477 & 1.39 & 3.98 & 0.155 & 8.99 \\
\hline $13 \mathrm{H}-2 \mathrm{~W}, 120-121$ & 93.44 & 2.15 & 0.900 & 1.25 & 7.51 & 0.128 & 9.72 \\
\hline $14 \mathrm{H}-2 \mathrm{~W}, 77-78$ & 98.08 & 2.37 & 0.813 & 1.56 & 6.78 & 0.132 & 11.8 \\
\hline $15 \mathrm{H}-2 \mathrm{~W}, 91-92$ & 106.62 & 2.67 & 1.07 & 1.60 & 8.91 & 0.161 & 9.94 \\
\hline $15 \mathrm{H}-3 \mathrm{~W}, 61-62$ & 107.47 & 2.26 & 0.882 & 1.37 & 7.36 & 0.142 & 9.63 \\
\hline $16 X-2 W, 120-121$ & 110.81 & 2.58 & 1.08 & 1.51 & 8.97 & 0.147 & 10.2 \\
\hline $16 X-4 W, 129-130$ & 113.79 & 1.79 & 0.169 & 1.62 & 1.41 & 0.175 & 9.22 \\
\hline $17 X-2 W, 122-123$ & 115.64 & 1.68 & 0.470 & 1.21 & 3.92 & 0.146 & 8.28 \\
\hline $17 X-4 W, 17-18$ & 117.61 & 1.20 & 0.379 & 0.824 & 3.16 & 0.112 & 7.35 \\
\hline $17 X-5 W, 69-70$ & 119.45 & 2.39 & 0.901 & 1.49 & 7.51 & 0.161 & 9.25 \\
\hline 18X-3W, 118-119 & 126.59 & 2.09 & 0.654 & 1.44 & 5.46 & 0.157 & 9.18 \\
\hline $19 X-3 W, 68-69$ & 135.74 & 2.05 & 0.810 & 1.24 & 6.75 & 0.153 & 8.12 \\
\hline 19X-3W, 129-130 & 136.35 & 2.48 & 1.06 & 1.42 & 8.85 & 0.161 & 8.80 \\
\hline $20 X-4 W, 28-29$ & 146.88 & 2.75 & 1.07 & 1.68 & 8.95 & 0.163 & 10.3 \\
\hline 20X-5W, 111-112 & 149.22 & 1.99 & 0.765 & 1.22 & 6.38 & 0.146 & 8.37 \\
\hline $21 X-1 W, 116-118$ & 152.96 & 1.63 & 0.437 & 1.19 & 3.65 & 0.156 & 7.65 \\
\hline 21X-1W, 117-119 & 152.97 & 1.66 & 0.473 & 1.19 & 3.94 & 0.151 & 7.83 \\
\hline 21X-2W, 89-91 & 154.19 & 1.79 & 0.512 & 1.28 & 4.27 & 0.157 & 8.16 \\
\hline $22 X-1 W, 128-129$ & 162.78 & 2.16 & 0.926 & 1.24 & 7.72 & 0.151 & 8.19 \\
\hline $22 X-3 W, 29-30$ & 164.52 & 1.55 & 0.405 & 1.15 & 3.38 & 0.150 & 7.64 \\
\hline $22 X-3 W, 67-68$ & 164.90 & 1.70 & 0.901 & 0.798 & 7.52 & 0.152 & 5.24 \\
\hline 23X-3W, 99-100 & 175.19 & 1.77 & 0.547 & 1.22 & 4.56 & 0.156 & 7.86 \\
\hline $23 X-4 W, 141-142$ & 176.81 & 1.89 & 0.817 & 1.07 & 6.82 & 0.147 & 7.31 \\
\hline $24 X-2 W, 65-66$ & 182.43 & 1.93 & 0.581 & 1.35 & 4.85 & 0.124 & 10.9 \\
\hline $24 X-3 W, 57-58$ & 183.16 & 2.05 & 0.845 & 1.21 & 7.05 & 0.145 & 8.30 \\
\hline 25X-5W, 140-142 & 194.86 & 1.60 & 0.593 & 1.01 & 4.95 & 0.108 & 9.35 \\
\hline
\end{tabular}

